\title{
A Benthic Carbon Budget for the Continental Slope off Cape Hatteras, N.C.
}

\author{
C.J. Thomas', N.E. Blair ', D.J. DeMaster ${ }^{1}$, R.A. Jahnke ${ }^{2}$ and C.S. Martens ${ }^{3}$. \\ ' Department of Marine, Earth, and Atmospheric Sciences, North Carolina State \\ University, Raleigh, N.C. $27695-8208$, USA \\ ${ }^{2}$ Skidaway Institute of Oceanography, 10 Ocean Science Circle, Savannah, G.A. \\ 31411 , USA \\ ${ }^{3}$ Department of Marine Sciences, University of North Carolina, Chapel Hill, N.C. \\ 27599-3300, USA
}

SUBMITTED TO DEEP SEA RESEARCH JANUARY 31, 1999 


\section{ABSTRACT}

The continental slope off Cape Hatteras, N.C. from approximately $36^{\circ} 00 \mathrm{~N}$ to $35^{\circ} 20^{\prime} \mathrm{N}$ is a region of relatively rapid sediment accumulation, organic matter deposition and subsequent remineralization. The measured fluxes are the highest reported for the slope off the eastern U.S. Sediment accumulation rates range from 40 to $140 \mathrm{~cm} \mathrm{ky}^{-1}$. Organic carbon deposition rates range from 3.5 to 7.4 moles $\mathrm{C} \mathrm{m}^{-2} \mathrm{yr}^{-1}$. The areal coverage of this "depocenter" is probably controlled by interactions between physical oceanographic processes and the rugged topography of the seafloor.

The organic matter deposited on the seafloor is primarily marine in origin and a mix of old and fresh particles. $73-93 \%$ of the depositing detritus is rapidly oxidized near the sediment/water interface. The controls on subsurface remineralization appear to be a complex function of the relative amount of metabolizable carbon delivered to the seabed both now and in the distant past ( $2500 \mathrm{ybp})$ and the extent of seabed irrigation. The age of DIC and $\mathrm{CH}_{4}$ produced within the seabed indicates that relatively young, reactive carbon is advected below the sediment surface and fuels subsurface remineralization. The stable isotopic composition of DIC produced within the seabed indicates the selective degradation of ${ }^{13} \mathrm{C}$-enriched fractions of the organic matter. The metabolizable fraction has a carbon isotopic signature of $\sim-18 \%$, while the organic matter that survives degradation and is buried has a $\delta^{13} \mathrm{C}$ closer to $-20 \%$.

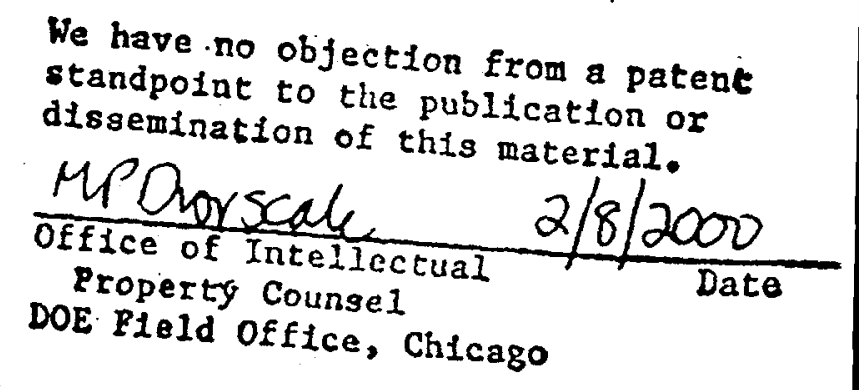




\section{DISCLAIMER}

This report was prepared as an account of work sponsored by an agency of the United States Government. Neither the United States Government nor any agency thereof, nor any of their employees, make any warranty, express or implied, or assumes any legal liability or responsibility for the accuracy, completeness, or usefulness of any information, apparatus, product, or process disclosed, or represents that its use would not infringe privately owned rights. Reference herein to any specific commercial product, process, or service by trade name, trademark, manufacturer, or otherwise does not necessarily constitute or imply its endorsement, recommendation, or favoring by the United States Government or any agency thereof. The views and opinions of authors expressed herein do not necessarily state or reflect those of the United States Government or any agency thereof. 


\section{DISCLAIMER}

Portions of this document may be illegible in electronic image products. Images are produced from the best available original document. 


\section{ABSTRACT}

The continental slope off Cape Hatteras, N.C. from approximately $36^{\circ} 00^{\prime} \mathrm{N}$ to $35^{\circ} 20^{\prime} \mathrm{N}$ is a region of relatively rapid sediment accumulation, organic matter deposition and subsequent remineralization. The measured fluxes are the highest reported for the slope off the eastern U.S. Sediment accumulation rates range from 40 to $140 \mathrm{~cm} \mathrm{ky}^{-1}$. Organic carbon deposition rates range from 3.5 to 7.4 moles $\mathrm{C} \mathrm{m}^{-2} \mathrm{yr}^{-1}$. The areal coverage of this "depocenter" is probably controlled by interactions between physical oceanographic processes and the rugged topography of the seafloor.

The organic matter deposited on the seafloor is primarily marine in origin and a mix of old and fresh particles. $73-93 \%$ of the depositing detritus is rapidly oxidized near the sediment/water interface. The controls on subsurface remineralization appear to be a complex function of the relative amount of metabolizable carbon delivered to the seabed both now and in the distant past ( $2500 \mathrm{ybp}$ ) and the extent of seabed irrigation. The age of DIC and $\mathrm{CH}_{4}$ produced within the seabed indicates that relatively young, reactive carbon is advected below the sediment surface and fuels subsurface remineralization. The stable isotopic composition of DIC produced within the seabed indicates the selective degradation of ${ }^{13} \mathrm{C}$-enriched fractions of the organic matter. The metabolizable fraction has a carbon isotopic signature of $\sim-18 \%$, while the organic matter that survives degradation and is buried has a $\delta^{13} \mathrm{C}$ closer to $-20 \%$. 


\section{INTRODUCTION}

The continental slope off Cape Hatteras has been proposed to be an area of enhanced carbon sequestration (Walsh et al. 1985). High animal densities are supported by elevated fluxes of organic material into the area (Rowe et al. 1988, Schaff et al. 1992, Blake and Grassle 1994). Rates of sediment accumulation and organic matter remineralization in the region off Cape Hatteras, N.C. are reportedly an order of magnitude higher (Blair et al. 1994 \& 1996, DeMaster et al. 1994) than those reported for the slope further north in the Mid-Atlantic Bight (Biscaye and Anderson 1994, Anderson et al. 1994) where a portion ( 11\%, Walsh 1994) of the particles produced on the continental shelf is exported onto the adjacent slope via complex currents, largely associated with storms (Biscaye and Anderson 1994, Brunner and Biscaye 1997).

The unique physical oceanography of the region directly off Cape Hatteras, N.C. generates optimal conditions for the transport of particles to and subsequent deposition on the continental slope. The southward flowing Virginia Current and northward flowing Gulf Stream converge at the cape, focusing particulate transport into the region. Episodic upwelling and coldcore ring formation associated with the convergence cause localized areas of elevated production (Janowitz and Pietrafesa 1980, Csanady and Hamilton 1988, Flagg et al. 1998). Quiescent, nearbottom conditions facilitate deposition (Csanady et al., 1988) of particles both exported from the adjacent shelf regions and produced over the slope. The bottom topography of steep canyons and gullies may further serve to funnel particles into the area (Biscaye and Anderson 1994, Suayah et $a l$. In prep.). Mass wasting is an important process shaping the geomorphology of this region (Prior 1986, Mellor and Paull 1994).

Though there is considerable evidence to indicate that the slope offshore of Cape Hatteras 
is a depocenter for sedimenting organic matter, there has not been a comprehensive benthic $\mathrm{C}$ budget prepared. To that end, this paper presents a benthic carbon budget for the continental slope directly off Cape Hatteras. In addition, the stable and radio-carbon isotopic compositions of remineralization products, as well as $\mathrm{POC}$ and animals, are used to characterize the metabolizable organic matter reaching the seabed. The data presented are used to refine our estimates of $\mathrm{C}$ preservation in slope sediments and evaluate the effects of non-steady state deposition on the early diagenesis of organic matter.

\section{METHODS}

Study area and sampling methods -- Sampling sites were part of the Department of Energy's Ocean Margin Program on the Cape Hatteras continental slope. Three transects were established along $36^{\circ} 20^{\circ} \mathrm{N}, 35^{\circ} 51 \mathrm{~N}$ and $35^{\circ} 25^{\prime} \mathrm{N}$ between 400 and $1500 \mathrm{~m}$ water depth (Table 1). An additional site was visited at $35^{\circ} 23 \mathrm{~N}, 74^{\circ} 48^{\prime} \mathrm{W}$. This site has been described previously (Kelchner 1992, Schaff et al. 1992, Blair et al. 1994, DeMaster et al. 1994, Blair et al. 1996, Levin et al. 1997) and is referred to as Site III. Stations were occupied during three cruises aboard the $R / V$ Cape Hatteras (September 1993), R/V Seaward Johnson (July 1996), and $R / V$ Edwin Link (August 1996). The submersible, $R / V$ Johnson Sea-Link, was used during the August 1996 cruise.

Sediment for ship board flux incubations was collected by submersible using a $15 \times 15 \times$ $20 \mathrm{~cm}$ Ekman-style box corer fitted with a $14.5 \mathrm{~cm}$-i.d. Lucite subcore. The round subcore was held in place by set screws. Sediments for dissolved inorganic carbon (DIC) production rate incubations were collected in $40 \mathrm{~cm}$ long push cores using the submersible. Samples for porewater, particulate organic carbon (POC) analyses and ${ }^{14} \mathrm{C}$ chronologies were collected using 
a $12 \mathrm{~cm} \times 12 \mathrm{~cm} \times 3 \mathrm{~m}$ kasten corer during all three cruises.

We suspect that surface-deployed coring techniques introduced a sampling bias that was caused by seafloor topography. Cores that impacted the relatively flat tops of ridges were probably recovered more successfully than deployments that intersected steep slopes. Cores could be efficiently collected from all three geographies using the submersible.

Experimental and analytical methods -- Benthic DIC fluxes were measured both in situ and during shipboard incubations. All shipboard incubations were conducted in darkness at $4^{\circ} \mathrm{C}$ and atmospheric pressure. After recovery of the Ekman box corers, the Lucite subcores were removed and closed at the bottom. The overlying water was gently aerated for several hours to allow the core to equilibrate to atmospheric pressure and incubation temperature. The cores were sealed at the top prior to the start of the incubations. Cores were gently stirred and monitored for DIC and $\mathrm{O}_{2}$ concentrations every 3-6 hours for 24 hours. DIC concentrations were determined on board ship by flow-injection analysis (Hall and Aller 1992). The precision of this technique is estimated to be $\pm 2 \% . \mathrm{O}_{2}$ concentrations were measured using a modified micro-Winkler technique (Strickland and Parsons 1972), which has a precision of $\pm 1 \%$. Aliquots of overlying water from each sample were sealed in glass ampoules for isotope analysis of DIC at N.C.S.U. (see description below).

In situ diffusive fluxes were determined using a free-vehicle lander and submersibleemplaced chambers. The free-vehicle benthic chamber instrument (BECI) inserted a $30 \times 30 \mathrm{~cm}$ titanium chamber, capped it and sampled the overlying water within the chamber every $2-3$ hours (Jahnke and Christiansen 1989). Samples were drawn into spring-loaded syringes and gas tight 
ampoules (for $\mathrm{O}_{2}$ analyses). At the beginning of each incubation $\mathrm{NaBr}$ was injected into the overlying water to be used to estimate chamber volume. $\mathrm{O}_{2}$, DIC, and nutrient concentrations were measured on samples recovered from the incubations. The smaller submersible-emplaced chamber operated in a similar fashion. The manually placed chamber allowed for control of placement adjacent to other experiments.

DIC production rates were determined using closed tube sediment incubations. Cut-off 60$\mathrm{ml}$ plastic syringes were used to subcore the top $5 \mathrm{~cm}$ of push cores collected by submersible. The sediment plugs were then sealed in the syringes with a butyl rubber stopper. Four syringes were filled from each core. Stoppered syringes were placed in half gallon Mason jars (Ball ${ }^{\mathrm{TM}}$ ). Then the jars were flushed with $\mathrm{N}_{2}$ and capped in a glove bag. One sediment plug was immediately processed for porewater DIC concentration, and the remaining plugs were incubated at $4^{\circ} \mathrm{C}$. Every 24 hours for three days, one incubation was ended and processed. DIC production rates $(R)$ were calculated using the following equation:

$$
R=(d C / d t) \phi_{x} h
$$

where,

$\mathrm{dC} / \mathrm{dt}=$ change in concentration with time $\left(\mu\right.$ moles $\left.\mathrm{cm}_{\mathrm{pw}}{ }^{-3} \mathrm{hr}^{-1}\right)$

$\phi_{\bar{x}}=$ average porosity for the $0-5 \mathrm{~cm}$ interval $\left(\mathrm{cm}_{\mathrm{pw}}{ }^{3} \mathrm{~cm}_{\mathrm{sed}}{ }^{-3}\right)$

$\mathrm{h}=$ height of incubated plug $\left(\mathrm{cm}_{\text {sed }}\right)$.

Porewater profiles of DIC $\delta{ }^{13} \mathrm{C}, \Delta^{14} \mathrm{C}$ and concentrations were determined on kasten cores. Sediment was subsampled using cut-off syringes. Porewater was separated by centrifuging the sediment in 30-ml Teflon centrifuge tubes at $7500 \mathrm{rpm}(5000 \mathrm{~g})$ for $15 \mathrm{~min}$. DIC concentrations 
of porewaters also were determined on board ship by flow-injection analysis (Hall and Aller 1992). Surplus porewater was sealed in glass ampoules for isotopic analyses. At N.C.S.U., the $\delta^{13} \mathrm{C}$ of the DIC was determined on one milliliter aliquots of porewater. Samples were placed in $3 \mathrm{ml}$ bottles and sealed with crimped rubber stoppers (Wheaton). The samples were acidified and the resulting $\mathrm{CO}_{2}$ was stripped with $\mathrm{He}$ and trapped cryogenically (Blair and Carter 1992). The ${ }^{13} \mathrm{C} /{ }^{12} \mathrm{C}$ ratio of the $\mathrm{CO}_{2}$ was measured on a modified Finnigan MAT Delta $\mathrm{E}$ isotope ratio mass spectrometer (Hayes et al. 1977). The precision of the vacuum line concentration measurements was $\pm 5 \%$. The precision of the carbon isotope measurements was $\pm 0.4 \%$. The isotopic signatures of the DIC samples were corrected for degassing during storage in the ampoules. Samples were assumed to have equilibrated with the headspace gas inside the containers. The corrected value $\left(\delta^{13} \mathrm{C}_{\mathrm{c}}\right)$ was calculated using the following equation:

$$
\delta^{13} C_{c}=\left(f \times \delta^{13} C_{m}\right)+(1-f)\left(\frac{\left(\delta^{13} C_{m}+1000\right)}{\alpha}-1000\right)
$$

where:

$f=$ DIC concentration after storage/concentration before storage $\delta^{13} C_{m r}=$ isotopic signature measured after storage $\alpha=$ fractionation factor for $\mathrm{CO}_{2}-\mathrm{HCO}_{3}^{-}$equilibrium (Friedman and $\mathrm{O}^{\prime} \mathrm{Neil}$ 1977).

$\Delta{ }^{14} \mathrm{C}$-DIC measurements were made on porewater that was processed using a modified procedure of the stable isotope protocol. Sediment was quickly collected in cut-off syringes and 
transferred to centrifuge tubes in a glove bag under $\mathrm{N}_{2}$. After centrifugation, the porewater was placed in ampoules under $\mathrm{N}_{2}$. At N.C.S.U. the samples were transferred to glass Wheaton bottles that had been previously flushed with $\mathrm{He}$. The bottles were crimp-sealed, and the DIC was converted to $\mathrm{CO}_{2}$ using the same method described above. The resultant gas was analyzed for its isotopic content by accelerator mass spectrometry at the Lawrence Livermore National Laboratory AMS Facility. The precision of the $\Delta^{14} \mathrm{C}$ measurements was $\pm 7 \%$, which translates to an error of $\pm 10 \%$ on the age estimates.

Porewater profiles of $\mathrm{CH}_{4}$ concentrations, $\delta^{13} \mathrm{C}$, and $\Delta^{14} \mathrm{C}$ were determined on kasten cores. Sediment targeted for $\mathrm{CH}_{4}$ concentration analyses was subsampled using 3-ml cut-off syringes. The sediment was then extruded into $50-\mathrm{ml}$ serum vials (Wheaton) containing $1 \mathrm{ml}$ of $3 \mathrm{M} \mathrm{NaOH}$ and sealed with rubber stoppers. $\mathrm{CH}_{4}$ concentrations were determined by gas chromatography on a Shimadzu Mini-2 GC using a molecular sieve 5A column (Alltech) and flame ionization detector. Analytical precision was $\pm 6 \%$. Based on previous observations, sample to sample variability could have been an order of magnitude greater due to the gaseous losses of $\mathrm{CH}_{4}$ during core retrieval and sampling.

Sediment targeted for $\mathrm{CH}_{4}$ isotopic analyses was collected in 60-ml cut-off syringes and extruded into one pint Mason jars that had been flushed with $\mathrm{N}_{2}$ and contained $20 \mathrm{ml}$ DI water. Samples were stored frozen. At N.C.S.U. the thawed samples were shaken vigorously for five minutes. Headspace gas was removed from the jar using a can piercing sampler (Alltech). The methane was converted to $\mathrm{CO}_{2}$ by passing it through a $790^{\circ} \mathrm{C}$ furnace packed with $\mathrm{CuO}$ (Matthews and Hayes 1978). The resultant $\mathrm{CO}_{2}$ was either analyzed for its ${ }^{13} \mathrm{C} /{ }^{12} \mathrm{C}$ or ${ }^{14} \mathrm{C} /{ }^{12} \mathrm{C}$ content as described above. Precision of the $\delta^{13} \mathrm{C}$ measurement was $0.3 \%$. The relative standard 
deviation on the $\Delta^{14} \mathrm{C}$ measurement was $\pm 6 \%$.

Particulate organic carbon data-- Particulate organic carbon ${ }^{14} \mathrm{C}$ ages, sediment porosities and dry bulk densities were determined at N.C.S.U. POC ${ }^{14} \mathrm{C}$ ages were determined following the procedures described in Harden et al. (1992) and DeMaster et al. (1994). POC concentrations and $\delta^{13} \mathrm{C}$ on sediment from all stations except Site III were generated at U.N.C.-Chapel Hill using a Carlo-Erba 1500 Elemental Analyzer. Small aliquots of sediment were weighed into aluminum boats. Vapor Phase acidification with $\mathrm{HCl}$ was used to remove carbonates prior to analyses (Hedges and Stern 1984). Precision on the concentration analyses was 3\%.

Particulate organic carbon concentrations and isotopic compositions of sediments from Site III were determined at N.C.S.U. Sediments were dried and then acidified with $4 \mathrm{~N} \mathrm{HCl}$. Sediments were redried and ground to a fine powder. Subsequently, several milligrams were combusted in a Carlo Erba 1108 CHNS analyzer (Blair and Carter 1992). The resultant $\mathrm{CO}_{2}$ was cryogenically collected and analyzed for its ${ }^{13} \mathrm{C} /{ }^{12} \mathrm{C}$ content as described above.

Grain size determinations -- Sediment from Site III (kasten core 142, CH93) was analyzed for its carbonate-free grain size distributions downcore. Approximately $5 \mathrm{~g}$ of dry sediment from each depth interval were acidified with $4 \mathrm{~N} \mathrm{HCl}$ to remove all carbonates. The sample was rinsed repeatedly with DI water until the $\mathrm{pH}$ reached 4 . Then the sediment was sonicated for 2 minutes and rinsed through nested 63 and $25 \mu \mathrm{m}$ sieves. The mud fraction that passed through the sieves was collected in a $1 \mathrm{~L}$ graduated cylinder for separation of mud and clay particles at $8 \mathrm{phi}(4 \mu \mathrm{m})$. Five mls of a $250 \mathrm{~g} \mathrm{~L}^{-1}$ solution of sodium metaphosphate were added to each cylinder, the 
volume brought to $1 \mathrm{~L}$ and allowed to equilibrate overnight. Subsequently, the samples were stirred for one minute and $20 \mathrm{mls}$ were removed $(\leq 4 \mathrm{phi})$. After $1 \mathrm{hr} 59 \mathrm{~min}$ at $19^{\circ} \mathrm{C}, 20 \mathrm{mls}$ were removed from a depth of $10 \mathrm{~cm}(\leq 8 \mathrm{phi})$. All of the grain-size samples were oven dried and weighed.

Calculation of budget terms -- Mass balance equations were used to model C fluxes within slope sediments. This method required the assumption that the system has been at steady state in terms of sediment accumulation and organic matter input over the last 5,000 y. Stations were considered to violate this assumption if the change in the ${ }^{14} \mathrm{C}$ age of $\mathrm{POC}$ downcore was not linear (least square fit, $r^{2} \leq 0.6$ ). All budget terms (i.e. fluxes and rates) were converted to the common units of moles $\mathrm{C} \mathrm{m}^{-2} \mathrm{yr}^{-1}$ to facilitate additional calculations and comparisons.

Organic carbon deposition rates $\left(\mathrm{J}_{\text {to }}\right)$ were estimated for four stations on the North Carolina slope by summing the flux of remineralization products $\left(\mathrm{J}_{\mathrm{diff}}\right)$ leaving the seabed with the total burial flux $\left(\mathrm{J}_{\mathrm{bur}}\right)$ of remineralization products in porewaters and of particulate organic matter escaping remineralization:

$$
J_{\text {tot }}=J_{\text {diff }}+\Sigma J_{b u r} .
$$

Error of $\mathrm{J}_{\text {tot }}$ was estimated by taking the square root of the sum of the squares of the standard deviations associated with the diffusive flux and POC burial terms. Porewater burial terms were not included in the propagation of error because multiple measures were not made, and the size of the terms was an insignificant portion of the total.

The diffusive flux ( $\mathrm{J}_{\text {diff }}, \mu$ moles $\mathrm{C} \mathrm{cm}^{-2} \mathrm{hr}^{-1}$ ) of DIC out of sediment contained in flux chambers was estimated using the following relationship: 


$$
J_{d i f f}=H \frac{d C}{d t}
$$

where,

$\mathrm{H}=$ height of headspace in the flux chamber $(\mathrm{cm})$

$\mathrm{dC} / \mathrm{dt}=$ linear concentration gradient with time $\left(\mu\right.$ moles $\left.\mathrm{cm}^{-3} \mathrm{hr}^{-1}\right)$.

Availability of flux measurements restricted the number of stations at which budget calculations could be made. Flux measurements were largely made on the August 1996 cruise when the July kasten coring stations were revisited with the submersible. As a result, fluxes were pooled with porewater and POC measurements made at the same coordinates on different dates. The water depth of collection given for each station is the depth from which the kasten core was collected. The water depths of flux measurements at a given site vary as much as $50 \mathrm{~m}$ due to the rugged topography of the seafloor.

Burial rates for dissolved species were determined using the following relationship:

$$
J_{b u r}=\phi_{z} \omega C_{z}
$$

where,

$$
\begin{aligned}
& \phi_{\mathrm{z}}=\text { sediment porosity at depth, } \mathrm{z}\left(\mathrm{cm}_{\mathrm{pw}}^{3} \mathrm{~cm}_{\text {sed }}^{-3}\right) \\
& \omega=\text { sediment accumulation rate }\left(\mathrm{cm}_{\mathrm{sed}} \mathrm{ky}^{-1}\right) \\
& \mathrm{C}_{\mathrm{z}}=\text { concentration of DIC or } \mathrm{CH}_{4} \text { at depth }(\mathrm{mM}) .
\end{aligned}
$$

Burial terms would ideally be calculated at depth where concentrations become asymptotic. 
However, in most cores, concentrations of dissolved species never reached that point. As a result, burial depth was defined as the deepest interval sampled for all carbon pools.

Burial rates for the POC fraction were calculated as follows:

$$
J_{b u r}=\omega \rho_{D B} C_{Z}
$$

where,

$$
\begin{aligned}
& \rho_{\mathrm{DB}}=\text { sediment dry bulk density at depth }\left(\mathrm{g}_{\mathrm{dry} \mathrm{sed}} \mathrm{cm}^{-3}{ }_{\text {wet sed }}\right) \\
& \left.\mathrm{C}_{\mathrm{z}}=\text { concentration of POC at the burial depth (moles } \mathrm{C}^{-1}{ }_{\mathrm{dry} \mathrm{sed}}\right) .
\end{aligned}
$$

\section{RESULTS AND DISCUSSION}

\section{Overview of site-specific carbon budgets}

Complete carbon budgets (i.e. containing estimates of organic carbon accumulation rate, benthic DIC fluxes, and $\mathrm{CH}_{4}+$ DIC porewater burial rates) could be constructed for four of the twelve study stations. Organic carbon deposition rates at the four sites were estimated to be 3.6 to 7.7 moles $\mathrm{C} \mathrm{m}^{-2} \mathrm{yr}^{-1}$ (Table 2). The carbon that is deposited in these locations appears to be marine in origin based on the $\delta^{13} \mathrm{C}$ composition $(\sim-21 \%)$ and $\mathrm{C} / \mathrm{N}$ weight percent ratio $(\sim 8)$ of the organic matter that accumulates. The ${ }^{14} \mathrm{C}$ ages of organic material at the sediment surface ranges from 500 (upslope, $400 \mathrm{~m}$ ) to $2500 \mathrm{ybp}$ (downslope, $1000 \mathrm{~m}$ ). Some portion of the particles sedimenting in this region of the slope are derived from higher latitude regions and may be heavily weathered. This is inferred from previous examinations of the clay mineralogy at Site III which revealed an abundance of chlorite, a high-latitude weathering product proposed to have originated in the Chesapeake Bay area (Kelchner 1992).

Some fraction of the POC reaching the seafloor is considerably younger and more labile 
than the POC that accumulates in the seabed. ${ }^{14} \mathrm{C}$ dating of benthic infauna collected in the study area gives modern ages and requires incorporation of nuclear bomb-tagged ${ }^{14} \mathrm{C}$ into body tissues (DeMaster et al. 1998, Blair et al. Submitted). Visual observations during submersible dives reveal a steady rain of marine snow and the occurrence of green phytodetritus near the bottom in these locations. Viable diatoms and measurable $\mathrm{Chl} a$ within the slope sediments also indicate the delivery of recently fixed carbon to the slope seafloor (Cahoon et al. 1994). Although at some locations the surface POC- ${ }^{14} \mathrm{C}$ ages are offset from the material that is accumulating below the surface (e.g. Site III, Fig. $1 \& 2$ ), the relatively old ages ( $2500 \mathrm{ybp}$ ) measured in most surface sediments and the high flux of DIC out of the seabed (Table 2) suggest that most young carbon deposited is quickly remineralized.

Diffusive loss of carbon from slope sediments is not limited to DIC. Fluxes of dissolved organic carbon (DOC) have been measured at one of the carbon budget sites, Station N740, on the $36^{\circ} 20^{\circ} \mathrm{N}$ transect (Alperin et al. Submitted.). The flux of DOC out of the sediment was estimated at 0.028 moles $\mathrm{C} \mathrm{m}^{-2} \mathrm{yr}^{-1}$. This loss is approximately $1 \%$ of the remineralization flux and is well within the level of error in the DIC flux measurements. For this reason, DOC flux out of the sediment was not included in carbon budget calculations.

Also not included in the budget was the loss of organic carbon through predation by demersal and pelagic species. Infauna biomass $(>300 \mu \mathrm{m})$ is by far most abundant at Site $\mathrm{II}$, averaging $54.5 \pm 14.4 \mathrm{~g}$ wet wt. $\mathrm{m}^{-2}$ (Schaff et al. 1992). Infauna is generally half as abundant at nearby slope sites (Blake and Grassle 1994). As a high end estimate, consider the following calculated loss of carbon due to predation. If we assume that the infauna were $40 \%$ water and 15 dry wt. \% OC 
(based on slope infauna analyzed at N.C.S.U.), then infauna biomass accounts for 0.4 moles C $\mathrm{m}^{-2}$. If all of this biomass were removed by predation annually, the loss is $\leq 10 \%$ of the carbon deposited on the seafloor and well within the error of the largest budget term, diffusive flux.

Approaching the predation issue from the consumer end of the trophic chain provides an additional estimate of the potential loss. Reported maximum fish densities at mid-slope depths (400-1000m) are 1-1.3 individuals $\mathrm{m}^{-2}$ (Hecker 1994). Most fishes in this environment weigh between 2 and $10 \mathrm{~g}$ wet weight (Sulak and Ross 1996). Using an average respiration rate reported for deep-sea fishes of 0.3 moles $\mathrm{O}_{2} \mathrm{~g}^{-1}$ wet w. $\mathrm{yr}^{-1}$ (Smith 1978, Smith and Laver 1981), an average fish weight of $5 \mathrm{~g}$, and the above densities, the respiration demand from demersal fishes at midslope depths is $1.5-1.9$ moles $\mathrm{O}_{2} \mathrm{~m}^{-2} \mathrm{yr}^{-1}$. If each mole of $\mathrm{O}_{2}$ consumed by the fish oxidizes one mole of $\mathrm{C}$, then the fishes must consume $1.5-1.9$ moles $\mathrm{C} \mathrm{m}^{-2} \mathrm{yr}^{-1}$ to create this metabolic demand. If the entire $\mathrm{C}$ demand is met by predation on benthic infauna, then the loss is equivalent to $25-50 \%$ of the diffusive fluxes recorded in this environment (Table 2). Without more accurate estimates of predation rates for this environment, this term cannot be assessed more directly.

Of the carbon that survives near-surface degradation and is advected below the interface, only a small amount $(1-7 \%)$ is remineralized within the upper $2-3 \mathrm{~m}$ of seabed (Table 2$)$. The age of the organic matter that is remineralized below the sediment surface at Stations S480,

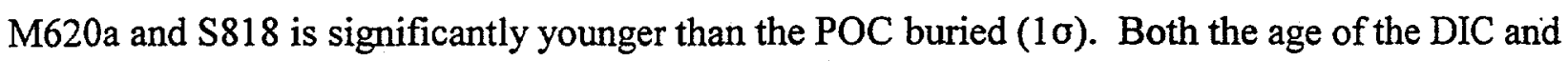
$\mathrm{CH}_{4}$ buried is offset from POC ages downcore (Fig. 3), again suggesting at least two pools of organic carbon, one younger and more reactive and another older and more recalcitrant. At one station, M415, both the $\mathrm{CH}_{4}$ and the DIC at depth are older than the POC (Fig.3). Either the 
fraction of the organic matter that is degraded at this station is old, or older DIC and $\mathrm{CH}_{4}$ are diffusing up from deeper in the sediment.

\section{Slope-wide variability in budget terms}

POC burial -- Variations in POC burial rates across the slope result from differences in sediment accumulation rates and weight percent OC. Sediment accumulation rates across the entire study region vary by a factor of less than four, ranging from 37 to $140 \mathrm{~cm} \mathrm{ky}^{-1}$ (DeMaster et al. 1998). On average, the rates are highest on the two southern transects and peak at water depths between 400 and $900 \mathrm{~m}$.

Conversely, mean sediment organic carbon content decreases to the south, averaging $2.6 \%$ (dry wt.) on the northernmost two transects and $1.5 \%$ on the southernmost transect and at Site III. The shift in organic carbon content may be the result of at least two processes. First, dilution from increased amounts of large sand-size particles could reduce the weight percent organic carbon in southern locations. Kelchner (1992) reports similar POC distributions for the region and used grain-size analyses to attribute lower levels in the area between $35^{\circ} 00^{\prime}$ and $35^{\circ} 30^{\prime}$ to an increase in the relative amount of silt and sand size particles. The bulk of those particles were planktonic foraminifera. Second, increased loading on fine particles sedimenting in northern regions could cause the relatively elevated percentages. We have no gauge of the occurrence or magnitude of the second process.

Depth distributions for POC concentrations, its $\delta^{13} \mathrm{C}$ and ${ }^{14} \mathrm{C}$ age for the budget stations are displayed in Fig. 1. They are typical of distributions found at other stations. Isotopic shifts in the upper $1 \mathrm{~m}$ are associated with an enrichment in the ${ }^{13} \mathrm{C}$ content of the POC at Stations S818 and 
Site III (Fig. 1). Though a diagenetic isotope effect cannot be ruled out a priori, the shifts in $\delta^{13} \mathrm{C}$ in these and other cores are most likely the result of source variations.

For example, at Station M811 (Fig. 2), downcore POC concentration changes are irregular, large (3-4\%), and associated with a depletion in ${ }^{13} \mathrm{C}$ content as compared to the other stations. These downcore shifts are associated with an offset in the ${ }^{14} \mathrm{C}$ ages of the POC (Fig. 2), suggesting that deposition at Station M811 has been non-steady state in the recent past. POC buried as shallow as $100 \mathrm{~cm}$ was produced before the Holocene, while POC ages in the upper $50 \mathrm{~cm}$ of the seabed range from 1000 to $9000 \mathrm{ybp}$. The $\delta^{13} \mathrm{C}$ and weight percent of the POC suggest at least three, and perhaps four, changes in the source of organic matter. Given the high accumulation rates for adjacent sites $\left(72-115 \mathrm{~cm} \mathrm{ky}^{-1}\right)$, it seems unlikely that an extended hiatus in deposition has caused the observed profiles. It is more likely that some mass-wasting event affected the sediment column in the past. Steady state accumulation may have resumed recently. The organic matter accumulating over the upper $20 \mathrm{~cm}$ or so resembles that accumulated at other stations on this transect ( $w t \% O C=2.5, \delta^{13} \mathrm{C}=-20.9$ ). Similar discontinuities in $\mathrm{POC}$ ages and $\delta^{13} \mathrm{C}$ are found at M620a, S480, S818 and Site III, suggesting non-steady state deposition (Figs. 1 $\& 2)$.

At Site III subsurface ${ }^{14} \mathrm{C}$ ages are consistently $\sim 2000 \mathrm{ybp}$ between 50 and $150 \mathrm{~cm}$ depth (Fig. 1) suggesting very rapid deposition. The vertical subsurface ${ }^{14} \mathrm{C}$ age profile at Site III requires cautious interpretation of accumulation rates. If sediment accumulation has been steadily rapid and the young offset at the surface of the core represents recent delivery of fresh detritus, the budget terms reported in Table 2 could be an order of magnitude higher. Conversely, if rapid accumulation of sediment occurred long ago( $>500)$, and deposition has been 
slower since then, the estimated burial rates in Table 2 may be too rapid relative to current rates.

A previous report of accumulation at the site supported the first scenario - rapid, steady state accumulation (DeMaster et al. 1994). A kasten core recovered from $1150 \mathrm{~m}$ of water at $35^{\circ}$ $24 \mathrm{~N}$ had a nearly vertical ${ }^{14} \mathrm{C}$ depth profile. The ${ }^{14} \mathrm{C}$ ages of the POC became somewhat younger downcore, but averaged an age of $2400 \mathrm{ybp}$ with no young offset at the sediment surface. Calculation of an accumulation rate from a vertical ${ }^{14} \mathrm{C}$ profile was impossible, so ${ }^{210} \mathrm{~Pb}$ profiles from the region between $35^{\circ} 20^{\prime}$ and $35^{\circ} 38 \mathrm{~N}$ were used to estimate the unusually high sediment accumulation rate of $\sim 1 \mathrm{~cm} \mathrm{yr}^{-1}$ (DeMaster et al. 1994)

While rapid, recent accumulation in the region cannot be ruled out, it seems likely that the ${ }^{210} \mathrm{~Pb}$ profiles were affected by bioturbation to the bottom of the short cores $(15-30 \mathrm{~cm})$. Biological mixing of the sediment would make the ${ }^{210} \mathrm{~Pb}$ profiles more vertical and increase the apparent accumulation rate (Benninger et al. 1979, Cochran and Aller 1979, Nittrouer et al. 1979). Porewater profiles from the region (Fig. 4) clearly show bioirrigation of the seabed to depths of $40 \mathrm{~cm}$ and deeper. It follows that biological transport of particles could also occur to these depths. X-ray images and biological mixing parameters for sediment in the region show rapid bioturbation to $20 \mathrm{~cm}$ that overshadows accumulation and strata formation (Diaz et al. 1994).

Additional evidence now available also supports the second scenario - non-steady state accumulation potentially including a mass-wasting event. First, ${ }^{234} \mathrm{Th}$ inventories do not suggest that recent deposition (last 100 days) at Site III has been any more rapid than at Station S818 where ${ }^{14} \mathrm{C}$ accumulation rates are considerably slower (Table 2 ). ${ }^{210} \mathrm{~Pb}$ inventories also vary little throughout the region, suggesting that delivery of organic particles over the last one hundred 
years has been similar at Site III and other locations slightly north of it (DeMaster et al. 1994, Suayah et al. In prep.).

Second, discontinuities occur in $\mathrm{POC}{ }^{14} \mathrm{C}$ age, grain size distributions, weight percent $\mathrm{C}$, and $\mathrm{POC} \delta^{13} \mathrm{C}$ at $60-65 \mathrm{~cm}$ deep in the sediment. The organic carbon age at the sediment surface is $1000 y$ younger than organic carbon deeper in the core. Carbonate-free grain size distributions shift from $70 \%$ sand and $30 \%$ silt + clay to a $50: 50$ mix. Weight percent carbonate is $8 \%$ over the upper $60 \mathrm{~cm}$. In the $60-65 \mathrm{~cm}$ interval, the same interval where the other discontinuities occur, the carbonate concentration drops to $6 \%$. Below that depth, the percentage is highest $(10 \%)$. Finally, the wt. \% OC shifts from 1.6 to $1.4 \%$, and the $\mathrm{POC} \delta^{13} \mathrm{C}$ shifts from -21 to $-20 \%$ (Fig. 1 ).

Similar isotopic shifts in both ${ }^{14} \mathrm{C}$ ages and $\mathrm{POC} \delta^{13} \mathrm{C}$ can be found in sediments at stations in close proximity to Site III (S480, S818, and M620b; Figs. 1 \& 2). The calculation of accumulation rates at non-steady state sites is tenuous; however, rates calculated above the transitions in the ${ }^{14} \mathrm{C}$-age profiles can be used to constrain the timing of the changes. Dividing the depth of the transition by accumulation rate yields similar dates of 550 and 540 years ago at Site III and Station S480, respectively. The transitions at Stations M620a and S818 appear to have occurred 1,200 and 2,700 years ago.

Benthic fluxes -- Benthic fluxes were not only variable from one station to another, but also variable at each study site. The standard deviation of fluxes were nearly as large as the mean flux at any given station. Fluxes at four sites (Stations N740, M620, S818, and Site III) were replicated four to nine times using in situ and shipboard techniques (Table 3). The large variances were due mainly to submersible-emplaced in situ fluxes (August 1996) that were 2-3 
times higher than fluxes obtained by shipboard incubations during the same cruise and lander deployments during the cruise in 1993. The range of values may reflect the patchiness of benthic communities in this dynamic environment (Blake and Hilbig 1994, Rhoads and Hecker 1994). The submersible-deployed chambers were specifically placed on high-accumulation rate plateaus where other experiments had to be deployed. These flat areas were not the normal topography, thus, it is unlikely that surface-deployed landers would sample these locations.

Additional experimental artifacts associated with the flux measurements cannot be ruled out. Porewater profiles suggest that irrigation represents a major transport mechanism. Other studies have provided evidence for irrigation at Site III (Blair et al. 1994, 1996, Submitted). However, irrigation did not appear to be an important mechanism for water exchange in any of the chambers. $\mathrm{Br}^{-}$tracer concentrations in chamber headspaces did not change significantly during lander and submersible-placed chamber incubations. Shipboard incubations chambers were sealed, preventing water exchange. If irrigation were inhibited, then the measured fluxes may have been too low. Because we had no gauge of the source of the variability, we chose to include all of the data when computing average fluxes for the sites used in the budget.

Across the entire study area, individual measurements of benthic fluxes of DIC out of the sediment ranged from 0.8 to 13.2 moles $\mathrm{C} \mathrm{m}^{-2} \mathrm{yr}^{-1}$. Fluxes of $\mathrm{O}_{2}$ into the sediment ranged from 0.7 to 9.9 moles $\mathrm{O}_{2} \mathrm{~m}^{-2} \mathrm{yr}^{-1}$. The magnitude of the fluxes was not clearly correlated with sediment accumulation rate or weight percent organic carbon. For example, Station S818 had the highest DIC flux of the budget stations and the lowest accumulation rate and weight percent organic carbon.

Sediment accumulation rates and weight percent organic carbon contents are not 
necessarily good proxies for assessing the delivery of reactive carbon. Organic-poor particles may dilute more reactive material, creating high delivery rates and low weight percent carbon. Conversely, high weight percent organic carbon does not insure high concentrations of labile organic matter. Non-steady state conditions may also restrict correlations between long-term accumulation rates and fluxes that are more responsive to short-termed variations in the delivery of organic material.

Benthic fluxes of DIC as measured in the flux chambers can be affected not only by the rate of organic matter oxidation, but also by seabed irrigation and carbonate dissolution (Aller 1982a). Aerobic oxidation of organic matter, $\mathrm{S}^{=}, \mathrm{Fe}^{+2}$ and $\mathrm{Mn}^{+2}$ can decrease alkalinity and cause carbonate dissolution to release an equivalent amount of DIC in carbonate-rich sediments (Emerson et al. 1982). In other words, the expected $\mathrm{DIC} / \mathrm{O}_{2}$ flux ratio would be 2 if a stoichiometric quantity of carbonate were dissolved. In general, the flux of DIC out of the sediment was balanced by the flux of $\mathrm{O}_{2}$ into the sediment (Table 3). The ratio of $\mathrm{DIC} / \mathrm{O}_{2}$ fluxes at the budget stations were $0.7-1.1$, indistinguishable from an ideal ratio of $0.9-1.0$ based on the complete oxidation of organic matter according to the Redfield ratio without dissolution (Emerson et al. 1980).

The sediments in the study region are well above the $\mathrm{CaCO}_{3}$ lysocline and have carbonate concentrations of 10-25 wt. \%. As a result, porewaters may be super-saturated with respect to $\mathrm{CO}_{3}=$. Acid production from remineralization reactions could titrate alkalinity without causing significant carbonate dissolution. The flux ratio of total alkalinity to $\mathrm{O}_{2}$ was approximately 1.7 because of the $\mathrm{NO}_{3}{ }^{-}$and $\mathrm{PO}_{4}{ }^{-3}$ coincidently released during remineralization. 
The DIC production incubations provided a measure of the rate at which organic matter can be degraded near the sediment surface. Rates at the budget stations were $4.7(n=1), 2.6 \pm$ $0.5(\mathrm{n}=2)$, and $3.1 \pm 0.01$ moles $\mathrm{C} \mathrm{m}^{-2} \mathrm{yr}^{-1}(\mathrm{n}=2)$ at Stations N740, M620, and S818, respectively. The DIC production rate from one other site on the $35^{\circ} 51 \mathrm{~N}$ transect at $543 \mathrm{~m}$ water depth was 3.2 moles $\mathrm{C} \mathrm{m}^{-2} \mathrm{yr}^{-1}$. These production rates indicate that $50-100 \%$ of organic remineralization in these sediments potentially occurs in the upper $5 \mathrm{~cm}$.

Porewater burial terms -- Porewater profiles of dissolved species also were variable across the slope region (Fig. 3). Nearly vertical profiles of low DIC concentrations and high $\delta^{13} \mathrm{C}$ indicate irrigation of overlying waters to depths of $\sim 40 \mathrm{~cm}$ in most cores. Deeper irrigation, as deep as $100 \mathrm{~cm}$ in many locations, is implicated by $\mathrm{SO}_{4}{ }^{=}$concentration profiles (Alperin et al. Submitted) and the occurrence of burrows to $>100 \mathrm{~cm}$ (visual observations). Two cores from Stations $\mathrm{S} 818$ and S1200 show no signs of irrigation.

Comparatively low DIC concentrations $(5-25 \mathrm{mM})$ at depth in sediments along the $36^{\circ} 20^{\circ} \mathrm{N}$ transect could be the result of irrigation or carbonate precipitation. Relatively high DIC production rates for surface sediment at Station N740 on this transect (Table 3) suggests that the low concentrations downcore may be either the result of oxidation localized in the upper $5 \mathrm{~cm}$ of sediment or some loss mechanism downcore. Alperin et al. (Submitted) report $\mathrm{Ca}^{++}$ concentrations that drop downcore indicating carbonate precipitation in sediment near the $36^{\circ}$ $20 \mathrm{~N}$ transect. Irrigation likely controls porewater concentrations at Stations N501 and N1027, because DIC concentrations at these stations are nearly constant downcore and only slightly higher than that of overlying water (Fig. 4). Given the high degree of patchiness over small 
spatial scales on the slope, this evidence can hardly be considered conclusive. Without ancillary data such as DIC $\delta^{13} \mathrm{C}$, the potential mechanisms are difficult to resolve.

Below the biologically irrigated zone, the ratio of $\mathrm{SO}_{4}{ }^{=}$consumed to the amount of DIC accumulating is approximately 2 at most locations indicating that the source of accumulating DIC is primarily $\mathrm{SO}_{4}{ }^{=}$reduction (Emerson et al. $1980, \mathrm{SO}_{4}{ }^{2}$ data from Alperin et al. Submitted). Plotting the concentration of DIC against its isotopic composition further helps to resolve the sources of porewater DIC (Fig. 5). An isotope mass balance (see discussion below) indicates that the organic material being degraded has an isotopic signature of $\sim-18 \%$. The ideal mixing curve shown in Fig. 5 represents the addition of $-18 \%$ DIC to overlying seawater assumed to contain $2 \mathrm{mM}$ DIC with a $\delta^{13} \mathrm{C}$ of $0 \%$. Deviations from the ideal curve indicate that processes other than the accumulation of organic material-derived DIC are affecting DIC concentrations and isotopic compositions.

Data from only two stations, S818 and S1200, (Fig. 5, Station S818 not shown)fall along the ideal mixing curve. Porewater profiles of DIC and $\mathrm{SO}_{4}{ }_{4}$ concentration at both Stations $\mathrm{S} 818$ and S1200 do not show signs of irrigation. In fact, the concave-down appearance of the profiles strongly suggests that DIC is diffusing up with little or no precipitation or advective loss (Reeburgh 1976, Martens and Berner 1977). As discussed in the preceding section, sediment low in organic carbon is accumulating slowly at these stations. Diffusive fluxes at Station S818 are high, indicating rapid oxidation of $\mathrm{OC}$ at the sediment/water interface. Subsurface degradation rates are apparently low, based on the lack of accumulating DIC and $\mathrm{CH}_{4}$ (Table 2). At Stations M415, M620a, S480 and Site III methanogenesis drives DIC $\delta^{13} \mathrm{C}$ values more positive as ${ }^{12} \mathrm{CO}_{2}$ is preferentially reduced to methane at depths $1.5-2.5 \mathrm{~m}$ deep in the sediment 
(Fig. $4 \& 5$ ). DIC concentrations reach $50-60 \mathrm{mM}$ at these stations and can be explained by the complete reduction of $25-30 \mathrm{mM} \mathrm{SO}_{4}{ }^{2}$ prior to methanogenesis as the porewater was buried.

The four stations with relatively shallow methane production all have current sediment accumulation rates over $100 \mathrm{~cm} \mathrm{ky}^{-1}$, comparatively high for this region. Stations M415, M620, and $\mathrm{S} 480$ all accumulate organic carbon at rates on the order of $2.0 \pm 0.1 \mathrm{moles} \mathrm{C} \mathrm{m}^{-2} \mathrm{yr}^{-1}$, and begin to produce methane somewhere between 150 and $200 \mathrm{~cm}$. Site $\mathrm{II}$ accumulates $\mathrm{OC}$ at a rate of $0.6 \pm 0.4$ moles $\mathrm{C} \mathrm{m}^{-2} \mathrm{yr}^{-1}$ and has the shallowest methanogenic zone. Station M1170 accumulates $\mathrm{OC}$ twice as quickly $\left(1.2\right.$ moles $\left.\mathrm{C} \mathrm{m}^{-2} \mathrm{yr}^{-1}\right)$ as Site III (based on the conservative accumulation rate estimate), yet methane is not produced within the top $2 \mathrm{~m}$ of sediment.

Methane production typically occurs at depths below where $\mathrm{SO}_{4}{ }^{2}$ concentrations become <1mM (Claypool and Kaplan 1974, Martens and Berner 1974). Accumulation rate and irrigation are thought to control the thickness of the $\mathrm{SO}_{4}{ }$ reduction zone (Reeburgh and Heggie 1977, Berner 1978, Reeburgh 1980, Blair in press). Accumulation rate clearly covaries with sulfate gradients over wide ranges of accumulation rates (Berner 1978); however, non-steady state accumulation and irrigation obscure the relationship on the North Carolina slope.

Present-day OC depositional environment is not an accurate predictor of shallow methane production in this region. Of the methanogenic cores, only station M415 has had steady state accumulation over the length of the core. Deposition at the other three methanogenic stations, M620a, S480 and Site III, apparently has not been steady state, and may have been very rapid in the past. The quality, composition and accumulation rate of the organic matter $500+$ years ago may be the factor controlling methane accumulation.

In addition, advection of $\mathrm{SO}_{4}{ }^{2}$-rich overlying water to depth during irrigation may expand 
the $\mathrm{SO}_{4}{ }^{=}$reducing zone, pushing the methanogenic zone deeper in locations where rapid accumulation should support shallower production (Reeburgh and Heggie 1977, Reeburgh 1980). Again, evidence for deep irrigation comes from porewater profiles and animal distributions. Deep burrowing crustaceans, tube building anemones and deep dwelling polychaetes are abundant in these areas and most likely responsible (Schaff et al. 1992, Blake and Hilbig 1994, Hecker 1994). This deep irrigation may be spatially patchy and temporally variable.

Associated with the methanogenic zone at these stations is an overlying zone of anaerobic methane oxidation that contributes to the DIC pool. Little if any methane was lost diffusively out the sediment water interface, because methane concentrations in surface sediments were approximately equal to those of the overlying water. The concave-up appearance of the methane profiles implies that $\mathrm{CH}_{4}$ is consumed as it diffuses upward (Fig. 4). Methane oxidation rates are estimated to be $0.05-0.09$ moles $\mathrm{C} \mathrm{m}^{-2} \mathrm{yr}^{-1}$ based on the porewater methane gradients. DIC $\delta^{13} \mathrm{C}$ values from intervals where methane oxidation occurs are offset from the ideal mixing curve due to the addition of ${ }^{13} \mathrm{C}$-depleted DIC (Fig.5).

In addition to the stations where the methanogenic zones were sampled, sediments collected at Stations M620a and M1 170 have $\mathrm{CH}_{4}$ profiles indicative of the oxidation of $\mathrm{CH}_{4}$ diffusing up from depth (Fig. 4). $\mathrm{CH}_{4}$ concentrations are low, and the profiles are concave-up in shape (Martens and Berner 1974). Sediments collected at Station M620b clearly became methanogenic at depths of $\sim 1.5 \mathrm{~m}$, therefore evidence of methane oxidation in the shorter core (1m) collected at M620a is not surprising.

The lack of methane production, coupled with low concentrations of ${ }^{13} \mathrm{C}$-depleted DIC, suggests in situ carbonate precipitation at Station M811 (Fig. 5). Calcite precipitation is 
generally inhibited in marine sediments by $\mathrm{Mg}^{2}, \mathrm{DOC}$ and dissolved sulfide (Garrels and Christ 1965, Berner 1975, Berner et al. 1978, Morse and Mackenzie 1990). However, given the extremely old age of the sediment at this station with the probable low $\mathrm{S}^{-}$and DOC concentrations (Alperin et al. Submitted), enough time may have elapsed for carbonate to precipitate. Pressure changes during core retrieval may cause additional precipitation, although the contribution is expected to be small (Murray et al. 1980).

\section{Isotope mass balance}

A complete carbon isotope mass balance can be constructed for Station M620, further characterizing the carbon isotopic composition of the metabolizable fraction (Table 4). The $\delta^{13} \mathrm{C}$ of the labile organic matter was estimated using three approaches to minimize potential biases and uncertainties that might be associated with any single methodology. The three approaches were based on the measured $\delta^{13} \mathrm{C}$ of the: 1) DIC fluxes, 2) benthic fauna, and 3) burial flux of DIC and $\mathrm{CH}_{4}$.

The magnitude and isotopic composition of the total benthic and the diffusive DIC fluxes were measured and calculated using two separate techniques. First, the isotopic composition of DIC in the overlying water was measured during three of the ship-board flux core incubations at Station M620b. The ratio of the change in concentrations of $\mathrm{DI}^{13} \mathrm{C} / \mathrm{DI}^{12} \mathrm{C}$ with time $\left(\mathrm{R}_{\mathrm{flux}}\right)$ was determined by the following relationship:

$$
R_{\text {flux }}=\frac{\left({ }^{13} D_{s}\right) \frac{d^{13} C}{d t}}{\left({ }^{12} D_{s}\right) \frac{d^{12} C}{d t}}
$$


where:

$$
\begin{aligned}
& \mathrm{C}=\text { concentration of } \mathrm{DI}^{13} \mathrm{C} \text { or } \mathrm{DI}{ }^{12} \mathrm{C} \\
& \mathrm{t}=\text { time } \\
& \mathrm{D}_{\mathrm{s}}=\text { diffusivity (assumed }{ }^{13} \mathrm{D} /{ }^{12} \mathrm{D}=1.0 \text {, Boehme et al. 1996). }
\end{aligned}
$$

The $\delta^{13} \mathrm{C}$ of the DIC flux out of the sediment was then calculated by inserting $\mathrm{R}_{\text {flux }}$ into the following equation:

$$
\delta^{13} C_{f l u x}=\left(1+\left(\frac{R_{f l u x}}{R_{s t d}}\right)\right) 10^{3} .
$$

where $\mathrm{R}_{\text {std }}$ is the ${ }^{13} \mathrm{C} /{ }^{12} \mathrm{C}$ ratio of the standard and equals 0.0112372 . The measured benthic flux was $5.7 \pm 4.0$ moles $\mathrm{C} \mathrm{m}^{-2} \mathrm{yr}^{-1}$ and had a $\delta^{13} \mathrm{C}$ of $-17.1 \pm 1.3 \%$.

In addition, the apparent diffusive flux supported by porewater concentrations in one tube core was calculated as above with $\mathrm{R}_{\text {flux }}$ defined by the gradient of ${ }^{12} \mathrm{C}$ and ${ }^{13} \mathrm{C}$ across the sediment/water interface. The magnitude of the supported flux was calculated using ( $\mathrm{Li}$ and Gregory 1974, Ullman and Aller 1982):

$$
J_{d i f f}=\Phi_{o}^{3} .\left(D_{o} \frac{\partial C}{\partial z}\right)
$$

where:

$$
\begin{aligned}
& \Phi_{\mathrm{o}}=\text { porosity at the surface }\left(0.82 \mathrm{~cm}_{\mathrm{pw}}^{3} / \mathrm{cm}^{3}{ }_{\text {wet sed }}\right) \\
& \partial \mathrm{C} / \partial \mathrm{z} \text { = linear concentration gradient across the interface } \\
& \mathrm{D}_{\mathrm{o}}=\text { free solution diffusivity of } \mathrm{HCO}_{3}{ }^{-}\left(0.0224 \mathrm{~cm}^{2} \mathrm{yr}^{-1}\right) \text {. }
\end{aligned}
$$

The concentration gradient supports a diffusive flux of 5.4 moles $\mathrm{C} \mathrm{m}^{-2} \mathrm{yr}^{-1}$ with a $\delta^{13} \mathrm{C}$ of 
$-18.9 \%$

Several factors other than the production of DIC via organic carbon oxidation may influence both the magnitude and isotopic composition of the flux. First, carbonate dissolution could shift the isotopic signature of the benthic flux. This mechanism would be exacerbated by acid produced during remineralization of $\mathrm{OC}$ and the oxidation of solid phase sulfides and by irrigation (Aller 1978 \& 1982b, McNichol et al. 1991, Green et al. 1992). Assuming that there is no fractionation associated with the oxidative degradation of $-21.3 \%$ POC and assuming an addition of carbonate with a $\delta^{13} \mathrm{C}$ of $1-2 \%$, an average range for shells and forams (McNichol et al. 1991, Berger and Killingley 1977), mass balance indicates that $18-20 \%$ of the diffusive flux would have to be from carbonate dissolution to shift the signal from -21.3 to $-17.1 \%$. As mentioned previously, dissolution does not likely occur to a large degree at this station because the $\mathrm{DIC} / \mathrm{O}_{2}$ flux ratio was 1.1 .

Second, there could be an isotope effect associated with chemosynthesis along burrow linings. The presence of bioturbating organisms enhances bacterial activities, including chemoautotrophic oxidation of $\mathrm{NH}_{4}{ }^{+}$and Fe-sulfides (Aller and Yingst 1978, 1985, Kristensen $e t$ al. 1985). Porewater DIC would be fractionated during autotrophic consumption of $\mathrm{CO}_{2}$ as a direct result of the isotope effect associated with ribulose 1,5 bisphosphate carboxylase (Schidlowski et al. 1983, Roeske and O'Leary 1984, Ruby et al. 1987). As mentioned above, high rates of sulfide and metal oxidation would drive carbonate dissolution as alkalinity is reduced during $\mathrm{CO}_{2}$ consumption and metal oxidation, further enriching porewaters in ${ }^{13} \mathrm{C}$. The additional fractionation from biosynthetic reactions could enrich the flux and reduce the amount of aerobic metabolism required to explain the signal. We cannot constrain the importance of this 
potential mechanism.

Third, the ${ }^{13} \mathrm{C}$-enrichment of DIC in deep-sea sediments has been argued to occur as a result of a steep pH gradient at the sediment water interface (Sayles and Curry 1988, Archer et al. 1989). If the DIC flux is sufficiently low, the $\mathrm{HCO}_{3}{ }^{-}$gradient is reversed, ${ }^{13} \mathrm{C}$-enriched bicarbonate diffuses into the sediment, and ${ }^{13} \mathrm{C}$-depleted $\mathrm{CO}_{2}$ diffuses out. This cannot be the explanation for the ${ }^{13} \mathrm{C}$-enrichment on the North Carolina slope, because the DIC flux out is not ${ }^{13} \mathrm{C}$-depleted, as would be predicted from the deep-sea model. In all likelihood, the presumed deep-sea process is not operative in coastal sediments in general. In near-shore sediments DIC fluxes are greater, and the net direction of bicarbonate diffusion is out of the seabed as demonstrated at Cape Lookout Bight, N.C. (Boehme et al. 1996).

Finally, the ${ }^{13} \mathrm{C}$-enriched benthic flux could be created by the selective degradation of a specific fraction of the POC, either organic matter from a specific source where a variety of sources are represented (Anderson 1994, Blair et al. 1994, Harvey 1994) or specific compound classes (McNichol et al. 1991). The enrichment most likely results from biodegradation of fresh marine carbon and burial of a mix of reworked marine and terrestrial material (Blair et al. 1994, DeMaster et al. 1994). Lipid markers for both marine and terrestrial material are found in these sediments (Harvey 1994). Terrestrial material typically is characterized by more ${ }^{13} \mathrm{C}$-depleted isotopic signatures (-25 to $-27 \%$ ) than marine material ( -19 to $-22 \%$, Anderson and Arthur 1984). Presumably any terrestrial material deposited at mid-slope depths is refractory, while the marine material could be either fresh or reworked.

Animals from colected from the areas have isotopic compositions that differ only slightly in $\delta^{13} \mathrm{C}$ but drastically in $\Delta^{14} \mathrm{C}$. Metazoans from stations $\mathrm{N} 740$ and $\mathrm{M} 620$ had average isotopic 
compositions of $-20.3 \pm 1.4(n=14)$ and $-18.6 \pm 1.5 \%(n=9)$. The $\delta^{13} \mathrm{C}$ of annelids at Site III is $-19.0 \pm 0.2 \%$ ( $\mathrm{n}=30$, Levin et al. In press). Generally, the isotopic signatures of consumers are similar to that of their food, but because the animals are at least one trophic level removed from the bulk organic matter in the sediment, they are often $\sim 1 \%$ enriched in ${ }^{13} \mathrm{C}$ than their diet (DeNiro and Epstein 1978, Rau et al. 1983, and many others). The animal's $\delta^{13} \mathrm{C}$ values therefore suggest that the diet of the animals could be anywhere from -18 to $-20 \%$. However, the ${ }^{14} \mathrm{C}$ ages of animals recovered from the region are modern indicating a selective diet of a young, reactive fraction (DeMaster et al. 1998, Blair et al. Submitted).

The $\delta^{13} \mathrm{C}$ of the organic matter deposited on the seafloor can be calculated using the following relationship:

$$
\delta J_{t o t}=\frac{\sum\left[\left(\delta J_{i}\right)\left(J_{i}\right)\right]}{\sum\left(J_{i}\right)}
$$

where $\mathrm{J}_{\mathrm{i}}=$ the diffusive and burial fluxes of DIC, $\mathrm{CH}_{4}$ and POC (Boehme et al. 1996). Because the magnitude of the benthic DIC flux term dominates $\mathrm{J}_{\text {tor }}$, its $\delta^{13} \mathrm{C}$ basically determines the $\delta \mathrm{J}_{\text {tot }}$ of $-17.8 \%$ (Table 4 ). Removing the POC burial term and simply examining the diffusive and burial fluxes of DIC and $\mathrm{CH}_{4}$ gives a remineralization flux $\left(\mathrm{J}_{\mathrm{rem}}\right)$ of 5.8 moles $\mathrm{C} \mathrm{m}^{-2} \mathrm{yr}^{-1}$ with a $\delta^{13} \mathrm{C}$ of $-17.1 \%$ (Table 4). Additionally, the burial flux of remineralization products (DIC + $\left.\mathrm{CH}_{4}\right)$ is 0.051 moles $\mathrm{C} \mathrm{m}^{-2} \mathrm{yr}^{-1}$ with an associated $\delta^{13} \mathrm{C}$ of $-17.4 \%$. Burial fluxes at five stations; Stations M415, M620, S480, S818 and Site III; have an average $\delta^{13} \mathrm{C}$ of $-17.6 \pm 1.7 \%$. The isotopically heavy porewater burial flux is probably not caused by carbonate dissolution. Alkalinity changes associated with $\mathrm{SO}_{4}{ }^{=}$reduction and methanogenesis are generally associated 
with carbonate precipitation, not dissolution (Pisciotto and Mahoney 1981, Gautier 1982).

In summary, most if not all of the DIC flux is directly related to organic matter oxidation. The similarity of the $\delta^{13} \mathrm{C}$ values of the buried remineralization products with the $\delta^{13} \mathrm{C}$ values of the diffusive DIC flux and the animals supports the conclusion that the metabolizable fraction of the organic matter has an isotopic composition $\left(\delta^{13} \mathrm{C}\right)$ of $-18 \pm 1 \%$. Comparison of this value to the isotopic composition of the bulk POC fraction suggests that certain organic carbon fractions are preferentially oxidized. These fractions are apparently marine in origin. The ${ }^{14} \mathrm{C}$ ages of animals, DIC and $\mathrm{CH}_{4}$ further indicate that this fraction is also younger than the bulk POC (Figure 3 and DeMaster et al. 1998).

\section{Location of Cape Hatteras "Depocenter"}

During the 1970's and 1980's the U.S. Department of Energy conducted the Shelf Edge Exchange Program (SEEP) experiment in two phases. SEEP-I examined the production and fate of organic particles in the northern Middle Atlantic Bight. SEEP-II focused on the southern end of the Mid-Atlantic Bight. This project has focused on the slope region off Cape Hatteras, N.C., a region immediately adjacent to the SEEP-II research area. Each program produced carbon budgets for the continental slope within its latitudinal range (Table 5) with the purpose of determining how much shelf production is deposited and sequestered within slope sediments. Methods for determining sediment accumulation and diffusive fluxes were similar in all three studies; however, deposition rates from the SEEP studies were determined from sediment trap data. The SEEP-II trap data were validated with the same calculations used in this study to estimate deposition rates, so comparisons between studies should be valid. 
Comparisons of the three budgets reveal clear latitudinal trends in sediment accumulation rates, diffusive fluxes, and therefore, deposition rates (Tables $2 \& 5$ ). More carbon is deposited in the rapidly accumulating sediments of the southern slope region off Cape Hatteras. This deposition in turn supports higher DIC diffusive fluxes. Interestingly, burial efficiencies do not vary significantly with latitude, and appear to be slightly lower to the south. Many factors may control burial efficiencies, including the relative mix of labile and recalcitrant source material deposited and the residence time of particles in the bioactive zone. The material that is deposited on the slopes of all three of the regions appears to be largely marine and a mix of old and fresh particles (Anderson et al. 1994, DeMaster et al. 1998). In addition, burial efficiency calculations will be biased in environments such as this because deposition has been non-steady state. Consequently, DIC flux measurements and estimated POC burial rates diverge as a result of the mismatched timescales each represents.

There are apparent trends within the budgets from this study that further constrain the region of elevated deposition and remineralization, in addition to the latitudinal trends from New England to Cape Hatteras. The fluxes and $\mathrm{C}$ budget at stations on the northernmost transect $\left(36^{\circ}\right.$ $20^{\prime}$ ) are quite similar to those described for the Mid-Atlantic Bight (Anderson et al. 1994, Tables $2 \& 5$ ). However, diffusive fluxes, POC burial rates and $\mathrm{OC}$ deposition rates nearly double on the $35^{\circ} 51^{\prime} \mathrm{N}$ transect and are elevated as far south as Site $\mathrm{III}$ at $35^{\circ} 23^{\prime} \mathrm{N}$. Accumulation and remineralization rates are lower further south at $34^{\circ} 15 \mathrm{~N}$ (Site II, Schaff et al. 1992, DeMaster et al. 1994, Blair et al. 1994) placing a rough southern limit on the location of the Cape Hatteras depocenter.

Not only are DIC and $\mathrm{O}_{2}$ diffusive fluxes, deposition, sediment accumulation and POC 
burial rates the highest reported for the western Atlantic, they are also higher than those reported for slope sediments off Washington and central California (Table 5). In fact, the sediment accumulation rates reported here are similar to those reported for the highly productive area off the coast of Peru. The carbon content of sediments on the Peru slope (2-3\%) and the resultant POC burial rates are similar to those reported here for the $35^{\circ} 51 \mathrm{~N}$ transect (Muller and Suess 1979, Walsh et al. 1985).

Although the POC burial rates and diffusive fluxes reported for the slope off Cape Hatteras are comparatively high for slope environments, they are lower than those reported for rapidly accumulating shelf environments such as Skan Bay, Alaska, Cape Lookout Bight (CLB), and the Amazon shelf. Reported organic carbon deposition rates for these locations are 1-2 orders of magnitude higher and support diffusive DIC fluxes of $15-40$ moles $\mathrm{C} \mathrm{m}^{-2} \mathrm{yr}^{-1}$ (Alperin et al. 1992, Martens et al. 1992, and Aller et al. 1996).

Present-day depocenters are largely identified as upwelling regions and areas undergoing eutrophication (Walsh et al. 1985). The area of elevated deposition described here is apparently defined by the convergence of the Virginia Current and the Gulf Stream. Oscillations in the position of the zone over hundreds or thousands of years may have caused episodic changes in the rate of delivery and composition of organic matter delivered to the seabed, in turn creating offsets in the organic carbon $\Delta^{14} \mathrm{C}$ and $\delta^{13} \mathrm{C}$ records. Future investigations should examine other convergence zones that may also function as depocenters, such as the slope off eastern Japan.

\section{CONCLUSIONS}

1. The continental slope off Cape Hatteras, N.C. from approximately $36^{\circ} 00^{\circ} \mathrm{N}$ to $35^{\circ} 20^{\circ} \mathrm{N}$ 
is a region of relatively high sediment accumulation, organic matter deposition and subsequent remineralization. The rates reported are the highest reported for the slope off of the eastern U.S. The areal coverage of this "depocenter" is probably controlled by interactions between physical oceanographic processes and the rugged topography of the seafloor.

2. Most of the organic matter deposited on the seafloor is marine in origin and reactive. Seabed preservation efficiencies range from 7 to $27 \%$. The age of $\mathrm{DIC}$ and $\mathrm{CH}_{4}$ produced within the seabed, as well as the age of infauna, indicate that relatively young, reactive carbon is advected below the sediment surface and fuels subsurface remineralization.

3. Non-steady state deposition of organic material affects subsurface remineralization. Some methane production may be the result of more rapid deposition in the past. In addition, present-day deep irrigation extends the zone of $\mathrm{SO}_{4}{ }^{=}$reduction, increasing the depth of biogenic methanogenesis.

4. The stable isotopic composition of DIC is produced within the seabed by the selective degradation of a fraction of the organic matter. This metabolizable apparently has a carbon isotopic signature of -17 to $-19 \%$, while the organic matter that survives degradation and is buried has a $\delta^{13} \mathrm{C}$ closer to $-20 \%$. Carbonate dissolution does not extensively affect the isotopic signature of the DIC subsequently fluxing out of and being buried in the seabed. 


\section{Acknowledgements}

We thank R. Aller, M. Alperin, D. Beauregard, W. Fornes, M. Green, H. Mendlovitz, G. Plaia, R. Pope, K. Perdue, and D. Zhu for their hard work during cruises and in the laboratory. The authors also thank the captains and crews of the $R / V$ Cape Hatteras, $R / V$ Seaward Johnson and $R / V$ Edwin Link. Helpful comments were provided by L. Cahoon, W. Fornes, R. Pope and W. Savidge on an early draft of this manuscript. This study was funded by grants from $\mathrm{DOE}_{\wedge}$ and NSF.

$$
\begin{gathered}
\text { (DE-FG02-850 } \\
\text { ER } 62082)
\end{gathered}
$$




\section{Literature Cited}

Aller, R.C., 1978. Experimental studies of changes produced by deposit feeders on pore water, sediment, and overlying water chemistry. American Journal of Science 278, 1185-1234.

Aller, R.C., 1982a. The effects of macrobenthos on chemical properties of marine sediment and overlying water. In: McCall, P.L., Tevesz, T.J.S. (Eds.), Animal Sediment Relations. Plenum Press, New York. Pp. 53-102.

Aller, R.C., 1982b. Carbonate dissolution in nearshore terrigenous muds: the role of physical and biological reworking. Journal of Geology 90, 79-95.

Aller, R.C., Blair, N.E., Xia, Q., Rude, P.D., 1996. Remineralization rates, recycling, and storage of carbon in Amazon shelf sediments. Continental Shelf Research 16, 753-786.

Aller, R.C., Yingst, J.Y., 1978. Biogeochemistry of tube-dwellings: a study of the sedentary polychaete Amphitrite ornata (Leidy). Journal of Marine Research 36, 201-254.

Aller, R.C., Yingst, J.Y., 1985. Effects of the marine deposit-feeders Heteromastus filiformis (Polychaeta), Macoma Balthica (Bivalvia), and Tellina texana (Bivalvia) on averaged sedimentary solute transport, reaction rates, and microbial distributions. Journal of Marine Research 43, 615-645.

Alperin, M.J., Martens, C.S., Albert, D.B., Suayah, I.B., Benninger, L.K., Blair, N.E., Jahnke, R.A., Submitted. Benthic fluxes and porewater concentration profiles of dissolved organic carbon in sediments from the North Carolina continental slope. Geochimica et Cosmochimica Acta.

Alperin, M.J., Reeburgh, W.S., Devol, A.H., 1992. Organic carbon remineralization and 
preservation in sediments of Skan Bay, Alaska. In: Whelan, J.K., Farrington, J.W. (Eds.), Organic Matter: Productivity, Accumulation, and Preservation in Recent and Ancient Sediments. Columbia University Press, New York. Pp. 99-122.

Anderson, T.F., Arthur, M.A., 1984. Stable isotopes of oxygen and carbon and their application to sedimentologic and paleoenvironmental problems. In: Arthur, M.A., Anderson, T.F., Kaplan, I.R., Veizer, J., Land, L.S. (Eds.), Stable isotopes in geology Society of Economic Paleontologists and Minerologists. Pp. 1-151.

Anderson, R.F., Rowe, G.T., Kemp, P.F., Trumbore, S., Biscaye, P.E., 1994. Carbon budget for the mid-slope depocenter of the Middle Atlantic Bight. Deep-Sea Research II 41, 669-703.

Archer, D., Emerson, S., Reimers, C., 1989. Dissolution of calcite in deep-sea sediments: pH and $\mathrm{O}_{2}$ microelectrode results. Geochimica et Cosmochimica Acta 53, 2831-2845.

Archer, D.E., Devol, A.H., 1992. Benthic oxygen fluxes on the Washington shelf and slope: A comparison of in situ microelectrode and chamber flux measurements. Limnology and Oceanography 37, 614-629.

Benninger, L.K., Aller, R.C., Cochran, J.K., Turekian, K.K., 1979. Effects of biological sediment mixing on the ${ }^{210} \mathrm{~Pb}$ chronology and trace metal distribution in a Long Island Sound sediment core. Earth and Planetary Science Letters 43, 241-259.

Berner, R.A., 1975. The role of magnesium in crystal growth of aragonite from seawater. Geochimica et Cosmochimica Acta 39, 489-505.

Berner, R.A., 1978. Sulfate reduction and the rate of deposition of marine sediments. Earth and Planetary Science Letters 37, 492-498. 
Berner, R.A., Westrich, J.T., Graber, R., Smith, J., Martens, C.S., 1978. Inhibition of aragonite precipitation from supersaturated sea water: A laboratory and field study. American Journal of Science $278,816-837$.

Biscaye, P.E., Anderson, R.F., 1994. Fluxes of particulate matter on the slope of the southern Middle Atlantic Bight: SEEP II. Deep-Sea Research II 41, 459-509.

Blair, N.E., In press. The $\delta^{13} \mathrm{C}$ of biogenic methane in marine sediments: The influence of $\mathrm{C}_{\text {org }}$ deposition rate. Isotope Geoscience.

Blair, N.E., Carter, Jr., W.D., 1992. The carbon isotope biogeochemistry of acetate from a methanogenic marine sediment. Geochimica et Cosmochimica Acta 56, 1247-1258.

Blair, N.E., Plaia, G.R., Boehme, S.E., DeMaster, D.J., Levin, L.A., 1994. The remineralization of organic carbon on the North Carolina continental slope. Deep-Sea Research II 41, 755-766.

Blair, N.E., Levin, L.A., DeMaster, D.J., Plaia, G., 1996. The short-term fate of fresh algal carbon in continental slope sediments. Limnology and Oceanography 41, 1208-1219.

Blair, N.E., Levin, L.A., DeMaster, D.J., Plaia, G., Martin, C., Fornes, W., Thomas, C., Pope, R., Submitted. The biogeochemistry of carbon in continental slope sediments. In: Aller, J. (Ed.) Organism-Sediment Interactions. University of South Carolina Press.

Blake, J.A., Grassle, J.F., 1994. Benthic community structure on the U.S. South Atlantic slope off the Carolinas: Spatial heterogeneity in a current-dominated system. Deep-Sea Research II 41, 835-874.

Boehme, S.E., Blair, N.E., Chanton, J.P., Martens, C.S., 1996. A mass balance of ${ }^{13} \mathrm{C}$ and ${ }^{12} \mathrm{C}$ in an organic-rich methane-producing marine sediment. Geochimica et Cosmochimica Acta 60, 
$3835-3848$.

Brunner, C.A., Biscaye, P.E., 1997. Storm-driven transport of foraminifers from the shelf to the upper slope, southern Middle Atlantic Bight. Continental Shelf Research 17, 491-508.

Cahoon, L.B., Laws, R.A., Thomas, C.J., 1994. Viable diatoms and chlorophyll $a$ in continental slope sediments off Cape Hatteras, North Carolina. Deep-Sea Research II 41, 767-782.

Canfield, D.E., Jørgensen, B.B., Fossing, H., Glud, R., Gundersen, J., Ramsing, N.B., Thamdrup, B., Hansen, J.W., Nielsen, L.P., Hall, P.O.J., 1993. Pathways of organic carbon oxidation in three continental margin sediments. Marine Geology 113, 27-40.

Claypool, G.E., Kaplan, I.R., 1974. The origin and distribution of methane in marine sediments. In: Kaplan, I.R. (Ed.), Natural Gases in Marine Sediments. Plenum Press, New York. Pp. 99-139.

Cochran, J.K., Aller, R.C., 1979. Particle reworking in sediments from the New York Bight Apex: evidence from ${ }^{234} \mathrm{Th} /{ }^{238} \mathrm{U}$ disequilibrium. Estuarine and Coastal Marine Science 9, 739747.

Csanady, G.T., Churchill, J.H., Butman, B., 1988. Near-bottom currents over the continental slope in the Mid-Atlantic Bight. Continental Shelf Research 8, 653-671.

Csanady, G.T., Hamilton, P., 1988. Circulation of slope water. Continental Shelf Research 8, 565-624.

DeMaster, D.J., Pope, R.H., Plaia, G., Blair, N.E., Levin, L.A., 1998. Organic carbon pathways and burial rates in North Carolina continental slope sediments. Eos Transactions, American Geophysical Union. Volume 79, Ocean Sciences Meeting Supplement, OS31. 
DeMaster, D.J., Pope, R.H., Levin, L.A., Blair, N.E., 1994. Biological mixing intensity and rates of organic carbon accumulation in North Carolina slope sediments. Deep-sea Research II 41, 735-753.

DeNiro, M.J., Epstein, S., 1978. Influence of diet on the distribution of carbon isotopes in animals. Geochimica et Cosmochimica Acta 42, 495-506.

Diaz, R.J.,. Cutter, G.R., Rhoads, D.C., 1994. The importance of bioturbation to continental slope sediment structure and benthic processes off Cape Hatteras, North Carolina. Deep-Sea Research II 41, 719-734.

Emerson, S., Jahnke, R., Bender, M., Froelich, P., Klinkhammer, G., Bowser, C., Setlock, G., 1980. Early diagenesis in sediments from the eastern equatorial Pacific, I. Pore water nutrient and carbonate results. Earth and Planetary Science Letters 49, 57-80.

Emerson, S., Grundmanis, V., Graham, D.W., 1982. Carbonate chemistry in marine pore waters: MANOP sites C and S. Earth and Planetary Science Letters 61, 220-232.

Flagg, C.N., Wallace, D., Kolber, Z., 1998. Cold anticyclonic eddies formed from cold pool water in the southern Middle Atlantic Bight. Continental Shelf Research 15, 1839-1867.

Fornes, W., 1996. Bioturbation and particle transport in Carolina slope sediments: A radiochemical approach. M.S. Thesis, North Carolina State University, Raleigh, N.C. 89 pp.

Friedman, I., O'Neil, J.R., 1977. Compilation of stable isotope fractionation factors of geochemical interest. U.S. Geological Survey Professional Paper 440-KK.

Garrels, R.M., Christ, C.L. (Eds.), 1965. Solutions, Minerals and Equilibria. Freeman, Cooper and Company, San Francisco. 450pp. 
Gautier, D.L., 1982. Siderite concretions: Indicators of early diagenesis in the Gammon shale (Cretaceous). Journal of Sedimentary Petrology 52, 859-871.

Green, M.A., Aller, R.C., Aller, J.Y., 1992. Experimental evaluation of the influences of biogenic reworking on carbonate preservation in nearshore sediments. Marine Geology 107, 175-181.

Hall, P.O.J., Aller, R.C., 1992. Rapid, small-volume flow injection analysis for $\mathrm{\Sigma CO}_{2}$ and $\mathrm{NH}_{4}{ }^{+}$ in marine and freshwaters. Limnology and Oceanography 37, 1113-1119.

Harden, S.L., DeMaster, D.J., Nittrouer, C.A., 1992. Developing sediment geochronologies for high-latitude continental shelf deposits: a radiochemical approach. Marine Geology 103, 69-97.

Hayes, J.M., DesMarais, D.J., Peterson, D.W., Schoeller, D.A., Taylor, S.P., 1977. High precision stable isotope ratios from microgram samples. Advances in Mass Spectrometry 7, 475480.

Hecker, B., 1994. Unusual megafaunal assemblages on the continental slope off Cape Hatteras. Deep-Sea Research II 41, 809-834.

Hedges, J.I., Stern, J.H., 1984. Carbon and nitrogren determinations of carbonate-containiong solids. Limnology and Oceanography 29, 657-663.

Henrichs, S.M., Farrington, J.W., 1984. Peru upwelling region sediments near $15^{\circ}$ S. 1 . Remineralization and accumulation of organic matter. Limnology and Oceanography 29, 1-19.

Jahnke, R.A., Christiansen, M.B., 1989. A free-vehicle benthic chamber instrument for sea floor studies. Deep-Sea Research 36, 625-637. 
Janowitz, G.S., Pietrafesa, L.J., 1980. A model and observations of time-dependent upwelling over the Mid-shelf and slope. Journal of Physical Oceanography 10, 1574-1583.

Kelchner, C.E., 1992. Organic-rich depositional regimes, NC continental slope: Evaluating source sites and sediment transport pathways. M.S. Thesis, North Carolina State University, Raleigh, N.C. 149 pp.

Kristensen, E., Jensen, M.H., Andersen, T.K., 1985. The impact of polychaete (Nereis virens Sars) burrows on nitrification and nitrate reduction in estuarine sediments. Journal of Experimental Marine Biology and Ecology 85, 75-91.

Levin, L., Blair, N., Martin, C., DeMaster, D., Plaia, G., Thomas, C. (In press) Macrofaunal processing of phytodetritus at two sites on the Carolina margin: In situ experiments using ${ }^{13} \mathrm{C}$ labeled diatoms. Marine Ecology Progress Series.

Levin, L., Blair, N., DeMaster, D., Plaia, G., Fornes, W., Martin, C., Thomas, C., 1997. Rapid subduction of organic matter by maldanid polychaetes on the North Carolina slope. Journal of Marine Research 55:595-611.

Li, Y.H., Gregory, S., 1974. Diffusion of ions in sea water and in deep-sea sediments. Geochimica et Cosmochimica 38, 703-714.

Martens, C.S., Berner, R.A., 1974. Methane production in the interstitial waters of sulfatedepleted marine sediments. Science 185, 1167-1169.

Martens, C.S., Berner, R.A., 1977. Interstitial water chemistry of Long Island Sound sediments. 1. Dissolved gases. Limnology and Oceanography 22, 10-25.

Martens, C.S., Haddad, R.I., Chanton, J.P., 1992. Organic matter accumulation, 
remineralization, and burial in an anoxic coastal sediment. In: Whelan, J.K., Farrington, J.W. (Eds.), Organic Matter: Productivity, Accumulation, and Preservation in Recent and Ancient Sediment. Columbia University Press, New York. Pp. 82-98.

Matthews, D.E., Hayes, J.M., 1978. Isotope-ratio-monitoring gas chromatography-mass spectrometry. Analytical Chemistry 50, 1465-1473.

McNichol, A.P., Druffel, E.R.M., Lee, C., 1991. Carbon cycling in coastal sediments: 2. An investigation of the sources of $\Sigma \mathrm{CO}_{2}$ to Pore Water using carbon isotopes. In: Baker, R.A. (Ed.), Organic Substances and Sediments in Water. Volume 2: Processes and Analytical. Lewis Publishers, Chelsea, Michigan. Pp. 249-272.

Mellor, C.A., Paull, C.K., 1994. Sea beam bathymetry of the Manteo 467 lease block off Cape Hatteras, North Carolina. Deep-Sea Research II 41, 711-718.

Morse, J.W., Mackenzie, F.T., 1990. Geochemistry of Sedimentary Carbonates. Elsevier, New York, New York. Pp.217-238.

Müller, P.J., Suess, E., 1979. Productivity, sedimentation rate, and sedimentary organic matter in the oceans -- I. Organic carbon preservation. Deep-Sea Research 26A, 1347-1362.

Nissenbaum, A., Kaplan, I.R., 1972. Chemical isotopic evidence for the in situ origin of marine humic substances. Limnology and Oceanography 17, 570-582.

Nissenbaum, A., Presley, B.J., Kaplan, I.R., 1972. Early diagenesis in a reducing fjord, Saanich Inlet, British Columbia, I. Chemical and isotopic changes in major components of interstitial water. Geochimica et Cosmochimica Acta 36, 1007-1027.

Nittrouer, C.A., Sternberg, R.W., Carpenter, R., Bennett, J.T., 1979. The use of ${ }^{210} \mathrm{~Pb}$ 
geochronology as a sedimentological tool: Application to the Washington continental shelf. Marine Geology 31, 297-316.

O'Leary, M.H., 1984. Measurement of the isotopic fractionation associated with diffusion of carbon dioxide in aqueous solution. Journal of Physical Chemistry 88, 823-825.

Pisciotto, K.A., Mahoney, J.J., 1981. 18. Isotopic survey of diagenetic carbonates, Deep Sea Drilling Project Leg 63. In: Yeats, R.S., Haq, B.U. (Eds.) Initial Reports of the Deep Sea Drilling Project, vol. 63. U.S. Government Printing Office, Washington. Pp. 595-610.

Rau, G.H., Mearns, A.J. Young, D.R., Olson, R.J., Schafer, H.A., Kaplan, I.R., 1983. Animal ${ }^{13} \mathrm{C} /{ }^{12} \mathrm{C}$ correlates with trophic level in pelagic food webs. Ecology $64,1314-1318$.

Reeburgh, W.S., 1976. Methane consumption in Cariaco Trench waters and sediments. Earth and Planetary Science Letters 28, 337-344.

Reeburgh, W.S., 1980. Anaerobic methane oxidation: Rate depth distributions in Skan Bay sediments. Earth and Planetary Science Letters 47, 345-352.

Reeburgh, W.S., Heggie, D.T., 1977. Microbial methane consumption reactions and their effect on methane distributions in freshwater and marine environments. Limnology and Oceanography $22,1-9$.

Reimers, C.E., Jahnke, R.A., McCorckle, D., 1992. Carbon fluxes and burial rates over the continental slope and rise off central California with implications for the global carbon cycle. Global Biogeochemical Cycles 6, 199-224.

Rhoads, D.C., Hecker, B., 1994. Processes on the continental slope off North Carolina with special reference to the Cape Hatteras region. Deep-Sea Research II 41, 965-980. 
Roeske, C.A., O'Leary, M., 1984. Carbon isotope effects on the enzyme catalyzed carboxylation of ribulose bisphosphate. Biochemistry 23, 6275-6284.

Rowe, G.T., Theroux, R., Phoel, W., Quinby, H.,Wilke, R., Koschoreck, D., Whitledge, T.E., Falkowski, P.G., Fray, C., 1988. Benthic carbon budgets for the continental shelf south of New England. Continental Shelf Research 8, 511-527.

Ruby, E.G., Jannasch, H.W., Deuser, W.G., 1987. Fractionation of stable carbon isotopes during chemoautotrophic growth of sulfur-oxidizing bacteria. Applied and Environmental Microbiology 53, 1940-1943.

Sayles, F.L., Curry, W.B., 1988. $\delta^{13}$ C, $\mathrm{TCO}_{2}$, and the metabolism of organic carbon in deep sea sediments. Geochimica et Cosmochimica Acta 52, 2963-2978.

Schaff, T., Levin, L., Blair, N., DeMaster, D., Pope, R., Boehme, S., 1992. Spatial heterogeneity of benthos on the North Carolina continental slope: Large $(100 \mathrm{~km})$-scale variation. Marine Ecology Progress Series 88, 143-160.

Schidlowski, M., Hayes, J.M., Kaplan, I.R., 1983. Isotopic inferences of ancient biochemistries: Carbon, sulfur, hydrogen, and nitrogen. In: Schopf, J.W. (Ed.), Earth's Earliest Biosphere. Princeton University Press, Princeton, New Jersey. Pp. 149-186.

Strickland, J.D.H., Parsons, T.R., 1972. A practical handbook of sea-water analysis, 2nd ed. Bulletin of the Fisheries Research Board Canada. 167 Pp.

Smith, K. L., 1978. Metabolism of the abyssopelagic rattail Coryphaenoides armatus measured in situ. Nature 274, 362-364.

Smith, K.L., Laver, M.B., 1981. Respiration of the bathypelagic fish Cyclothone acclinidens. 
Marine Biology 61, 261-266.

Sulak, K.J., Ross, S.W., 1996. Lilliputian bottom fish fauna of the Hatteras upper middle continental slope. Journal of Fish Biology 49A, 91-113.

Suayah, I.B., Alperin, M.J., Benninger, L.K., Martens, C.S., In prep. Coupling ${ }^{210} \mathrm{~Pb}$ and fallout ${ }^{239.240} \mathrm{Pu}$ to resolve the effects of mixing from sediment chronology on the Hatteras slope. Geochimica et Cosmochimica Acta.

Ullman, W.J., Aller, R.C., 1982. Diffusion coefficients in nearshore marine sediments. Limnology and Oceanography 27, 552-556.

Unver, A.A., Himmelblau, D.M., 1964. Diffusion coefficients of $\mathrm{CO}_{2}, \mathrm{C}_{2} \mathrm{H}_{4}, \mathrm{C}_{3} \mathrm{H}_{6}$, and $\mathrm{C}_{4} \mathrm{H}_{8}$ in water from $6^{\circ}$ to $65^{\circ}$ C. Journal of Chemical Engineering Data 9, 428-431.

Walsh, J.J., Premuzic, E.T., Gaffney, J.S., Rowe, G.T., Harbottle, G., Stoenner, R.W., Balsam, W.L., Betzer, P.R., Macko, S.A., 1985. Organic storage of $\mathrm{CO}_{2}$ on the continental slope off the Mid-Atlantic Bight, the southeastern Bering Sea, and the Peru coast. Deep-Sea Research 32, 853-883.

Walsh, J.J., Biscaye, P.R., Csanady, G.T., 1988. The 1983-1984 Shelf Edge Exchange Processes (SEEP)--I experiment: Hypothesis and highlights. Continental Shelf Research 8, 435-456.

Walsh, J.J., 1994. Particle export at Cape Hatteras. Deep-Sea Research II 41, 603-628. 
Table 1. Locations of sampling stations.

\begin{tabular}{cll}
\hline Transect & Station & Depth (m) \\
\hline $36^{\circ} 20^{\prime}$ & N501 & 501 \\
& N740 & 740 \\
& N1027 & 1027 \\
$35^{\circ} 51^{\prime}$ & M415 & 415 \\
& M620 & 620 \\
& M811 & 811 \\
& M1170 & 1170 \\
& & \\
$35^{\circ} 25^{\prime}$ & S295 & 295 \\
& S480 & 480 \\
& S818 & 818 \\
& S1200 & 1200 \\
$35^{\circ} 23^{\prime}$ & Site III & 850 \\
\hline
\end{tabular}


Table 2. Carbon budgets for four continental slope sites off Cape Hatteras, NC. Reported depths are for kasten core deployments at each site. Units are moles $\mathrm{C} \mathrm{m}^{-2} \mathrm{yr}^{-1} \pm \mathrm{S} . \mathrm{D}$., unless otherwise noted. Data for DIC fluxes and production rates are pooled from sub deployments at the same coordinates. Water depths recorded during sub core collection deviate as much as $50 \mathrm{~m}$ from depths recorded during Kasten core collection. N.d. means no data collected.

\begin{tabular}{|c|c|c|c|c|}
\hline \multirow{2}{*}{$\begin{array}{l}\text { Station } \\
\text { Transect } \\
\text { Water Depth (m) } \\
{ }^{14} \mathrm{C} \text { Accumulation Rate }\left(\mathrm{cm} \mathrm{ky}^{-1}\right)^{\dagger}\end{array}$} & $\begin{array}{r}\mathrm{N} 740 \\
36^{\circ} 20^{\prime} \\
740 \\
\end{array}$ & $\begin{array}{r}M 620 \\
35^{\circ} 51^{\prime} \\
620 \\
\end{array}$ & $\begin{array}{c}\mathrm{S} 818 \\
35^{\circ} 25^{\prime} \\
818 \\
\end{array}$ & $\begin{array}{c}\text { Site III } \\
35^{\circ} 23^{\prime} \\
850 \\
\end{array}$ \\
\hline & $84 \pm 5$ & $115 \pm 4$ & $37 \pm 4$ & $108 \pm 57$ \\
\hline Weight \% Organic Carbon & $2.5 \pm 0.2^{*}$ & $2.7 \pm 0.3^{*}$ & $1.4 \pm 0.2^{*}$ & $1.4 \pm 0.1$ \\
\hline 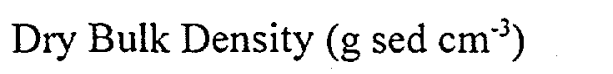 & 0.40 & 0.68 & 1.07 & 0.43 \\
\hline Burial Depth for Calculations (cm) & 225 & 175 & 185 & 125 \\
\hline${ }^{234} \mathrm{Th}$ inventory $\left(\mathrm{dpm} \mathrm{cm}^{-2}\right)$ & $\begin{array}{c}2.9 \pm 0.5 \\
(n=4)\end{array}$ & $\begin{array}{c}9.9 \\
(\mathrm{n}=1) \\
\end{array}$ & $\begin{array}{c}30.6 \pm 9.5 \\
(\mathrm{n}=2) \\
\end{array}$ & $\begin{array}{c}28.4 \pm 7.9^{++} \\
(\mathrm{n}=5)\end{array}$ \\
\hline Minimum $C_{\text {org }}$ Deposition Rate & $3.6 \pm 3.3$ & $7.7 \pm 4.0$ & $7.2 \pm 3.7$ & $4.3 \pm 1.1$ \\
\hline DIC Diffusive Flux & $\begin{aligned} 2.9 & \pm 2.8 \\
(\mathrm{n} & =9)\end{aligned}$ & $\begin{array}{c}5.7 \pm 4.0 \\
(\mathrm{n}=6)\end{array}$ & $\begin{array}{c}6.7 \pm 3.7 \\
(n=4)\end{array}$ & $\begin{array}{c}3.7 \pm 1.0 \\
(n=4)\end{array}$ \\
\hline \multirow[t]{2}{*}{ Porewater Burial: } & 0.01 & 0.05 & 0.004 & 0.04 \\
\hline & n.d. & $1.0 \times 10^{-3}$ & $2.0 \times 10^{-6}$ & $2.0 \times 10^{-3}$ \\
\hline POC Burial & $0.7 \pm 0.04$ & $2.0 \pm 0.1$ & $0.5 \pm 0.06$ & $0.6 \pm 0.35$ \\
\hline Preservation Efficiency $(\%)^{\ddagger}$ & $20 \pm 22$ & $27 \pm 14$ & $7 \pm 3$ & $14 \pm 9$ \\
\hline
\end{tabular}

* From Martens et al. (In prep.)

${ }^{++}$From Fornes (1996)

$\dagger$ Values are the slope \pm standard error of a line fit by least squares to ${ }^{14} \mathrm{C}$ ages and depth.

$\ddagger \begin{gathered}\text { Preservation } \\ \text { Efficiency }\end{gathered}=\frac{\text { POC Burial Rate }}{\text { Deposition Rate }} \times 100$ 
Table 3. Diffusive fluxes and DIC production rates at four sites on the Cape Hatteras continental slope.

\begin{tabular}{|c|c|c|c|c|}
\hline $\begin{array}{l}\text { Station } \\
\text { Transect }\end{array}$ & $\begin{array}{c}\mathrm{N} 740 \\
36^{\circ} 20^{\prime} \mathrm{N} \\
\end{array}$ & $\begin{array}{c}\text { M620 } \\
35^{\circ} 51^{\prime} N \\
\end{array}$ & $\begin{array}{c}\mathrm{S} 818 \\
35^{\circ} 25^{\prime} \mathrm{N} \\
\end{array}$ & $\begin{array}{r}\text { Site III } \\
35^{\circ} 23^{\prime} N \\
\end{array}$ \\
\hline $\begin{array}{l}\text { DIC Flux } \\
\left(\text { moles } \mathrm{C} \mathrm{m}^{-2} \mathrm{yr}^{-1} \text { ) }\right.\end{array}$ & $\begin{array}{c}2.9 \pm 2.8 \\
(\mathrm{n}=9)\end{array}$ & $\begin{array}{l}5.7 \pm 4.0 \\
(\mathrm{n}=6)\end{array}$ & $\begin{array}{c}6.7 \pm 3.7 \\
(n=4)\end{array}$ & $\begin{array}{c}3.7 \pm 1.0 \\
(n=4)\end{array}$ \\
\hline $\begin{array}{l}\mathrm{O}_{2} \text { Flux } \\
\left(\text { moles } \mathrm{O}_{2} \mathrm{~m}^{-2} \mathrm{yr}^{-1}\right)\end{array}$ & $\begin{array}{c}3.9 \pm 1.8 \\
(\mathrm{n}=8)\end{array}$ & $\begin{array}{c}5.3 \pm 2.9 \\
(n=6)\end{array}$ & $\begin{array}{c}5.8 \pm 3.8 \\
(n=4)\end{array}$ & $\begin{array}{l}3.8 \pm 0.7 \\
(\mathrm{n}=4)\end{array}$ \\
\hline $\begin{array}{l}\text { DIC Production } \\
\left.\text { (moles } \mathrm{C}^{-2} \mathrm{yr}^{-1}\right)\end{array}$ & $\begin{array}{c}4.7 \\
(n=1)\end{array}$ & $\begin{array}{c}2.6 \pm 0.5 \\
(n=2)\end{array}$ & $\begin{array}{c}3.1 \pm 0.01 \\
(n=2)\end{array}$ & \\
\hline $\mathrm{DIC} / \mathrm{O}_{2}$ Flux Ratio & 0.7 & 1.1 & 1.1 & 1.0 \\
\hline
\end{tabular}


Table 4. Carbon isotope mass balance for Station M620 on the $35^{\circ} 51 \mathrm{~N}$ transect.

\begin{tabular}{lcc}
\hline & $\mathbf{J}$ & $\delta{ }^{13} \mathbf{C}$ \\
& $\left(\mathbf{m o l e s ~ m}^{-2} \mathbf{y r}^{-1}\right)$ & $(\%)$ \\
\hline DIC & & \\
Diffusive & $5.7 \pm 4.0$ & $-17.1 \pm 1.3$ \\
Buried & 0.05 & -16.0 \\
\hline $\mathbf{C H}_{4}$ & & \\
Buried & 0.001 & -86.2 \\
\hline $\mathbf{J}_{\text {rem }}$ & 5.8 & -17.1 \\
\hline POC & & \\
Buried & 1.6 & -20.9 \\
\hline $\mathbf{J}_{\text {tot }}$ & 7.4 & -17.8 \\
\hline
\end{tabular}


Table 5. Carbon budgets for other slope sediments. Units are moles $\mathrm{C} \mathrm{m}^{-2} \mathrm{yr}^{-1}$ unless otherwise noted. N.r. means not reported. Compiled from: Müller and Suess 1979, Henrichs and Farrington 1984, Walsh et al. 1985, Walsh et al. 1988, Rowe et al. 1988, Anderson et al. 1988, Archer and Devol 1992, Reimers et al. 1992, and Anderson et al. 1994.

\begin{tabular}{lccccc}
\hline Budget Term & $\begin{array}{c}\text { Slope off Cape } \\
\text { Cod (SEEP-I) }\end{array}$ & $\begin{array}{c}\text { Mid-Atlantic Bight } \\
\text { (SEEP-II) }\end{array}$ & $\begin{array}{c}\text { Washington } \\
\text { Slope }\end{array}$ & $\begin{array}{c}\text { Central } \\
\text { California Slope }\end{array}$ & Peru \\
\hline$\omega--\mathrm{cm} \mathrm{ky}^{-1}$ & $10-20$ & $30-60$ & n.r. & $1.3-77$ & $66-140$ \\
$\mathrm{~g}_{\text {sed }} \mathrm{cm}^{-2} \mathrm{yr}^{-1}$ & 0.02 & $0.02-0.05$ & $0.02-0.05$ & n.r. & n.r. \\
Wt. \% OC & 1 & $1-3$ & 2.7 & $0.7-4.3$ & $2-3$ \\
OC Deposition Rate & $1-2$ & 2 & 3 & $0.4-1$ & \\
C Equivalent $\mathrm{O}_{2}$ Flux* & $0.2-0.4$ & $1.5-2.1$ & 0.8 & $0.05-0.5$ & \\
POC Burial & $0.1-0.2$ & $0.5-1.0$ & 1.1 & $0.02-0.3$ & 3 \\
Burial Efficiency (\%) & 20 & $25-50$ & 35 & $5-30$ & 12 \\
\hline
\end{tabular}

* DIC fluxes out of the sediment were not actually measured, instead the authors estimated the DIC flux from measured $\mathrm{O}_{2}$ fluxes. 


\section{Figure Legends}

Fig. 1. POC ${ }^{14} \mathrm{C}$ ages, wt. $\% O C$, and $\delta^{13} \mathrm{C} P O C$ for the four budget stations. The regressions between POC ${ }^{14} \mathrm{C}$ ages and depth used to generate sediment accumulation rates are shown in the upper panels.

Fig. 2. POC ${ }^{14} \mathrm{C}$ ages, wt. $\% \mathrm{OC}$, and $\delta^{13} \mathrm{C} \mathrm{POC}$ for non-steady state stations.

Fig. 3. ${ }^{14} \mathrm{C}$ ages of POC, DIC and $\mathrm{CH}_{4}$ from kasten cores collected at four locations on the N.C. continental slope.

Fig. 4. Porewater profiles of $\delta^{13} \mathrm{C} \mathrm{DIC}$ and $\mathrm{DIC}$ and $\mathrm{CH}_{4}$ concentrations in slope sediments. Actual $\mathrm{CH}_{4}$ concentrations are $100 \mathrm{x}$ higher than shown in the $\left(^{*}\right)$ plots.

Fig. 5. The concentration versus $\delta^{13} \mathrm{C}$ value of porewater DIC. Solid and broken lines represent the mixing curve for the addition of DIC with a $\delta^{13} \mathrm{C}$ of $-18 \pm 1 \%$ to bottom water $(2 \mathrm{mM}, 0 \%$ ). 

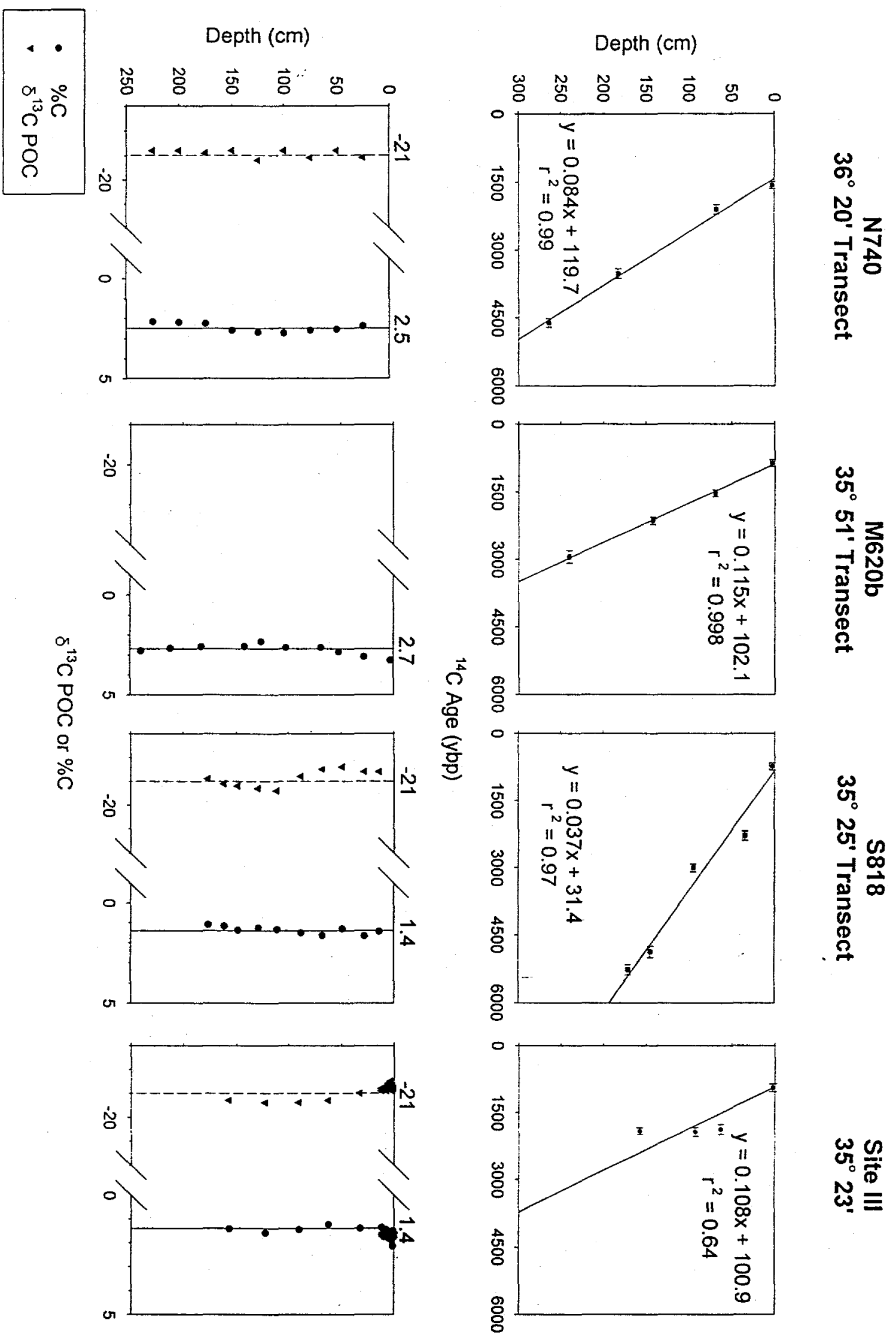

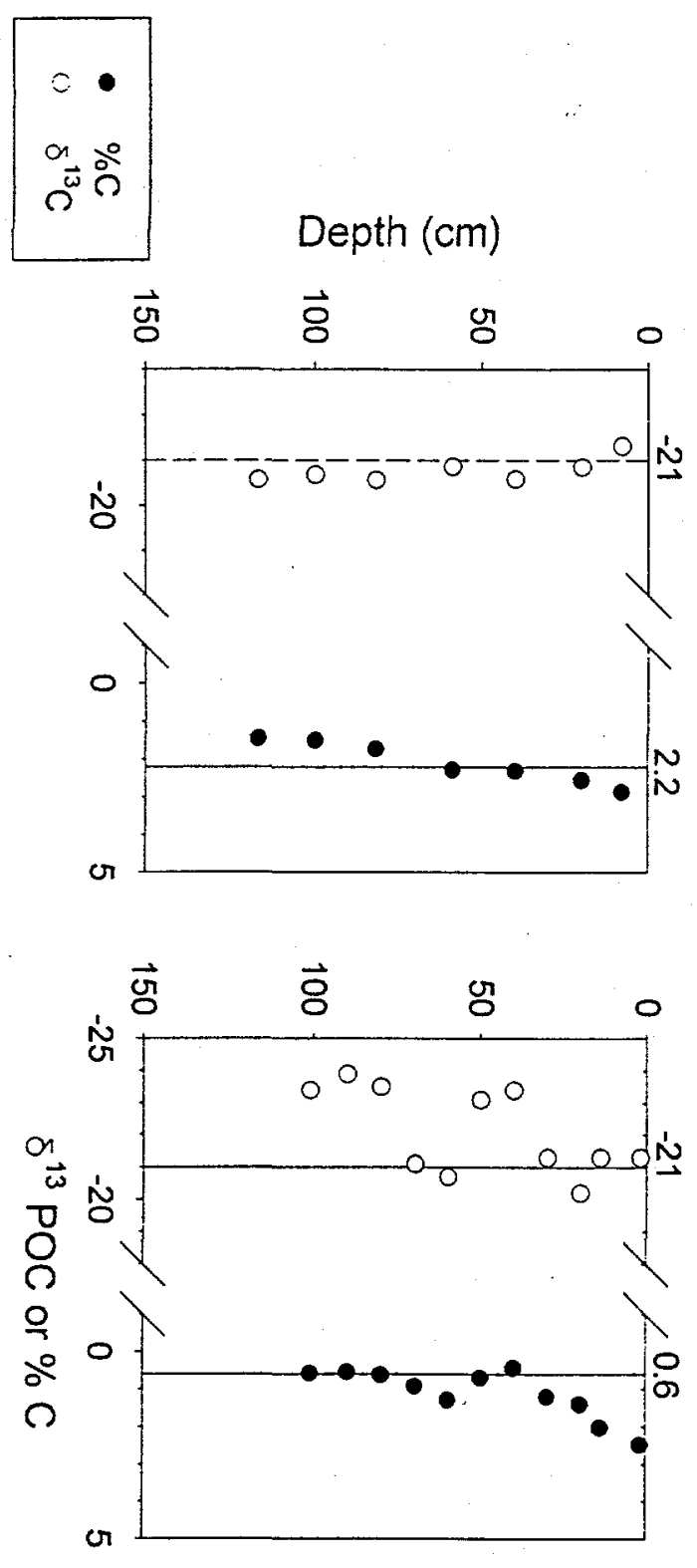

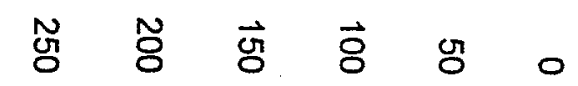

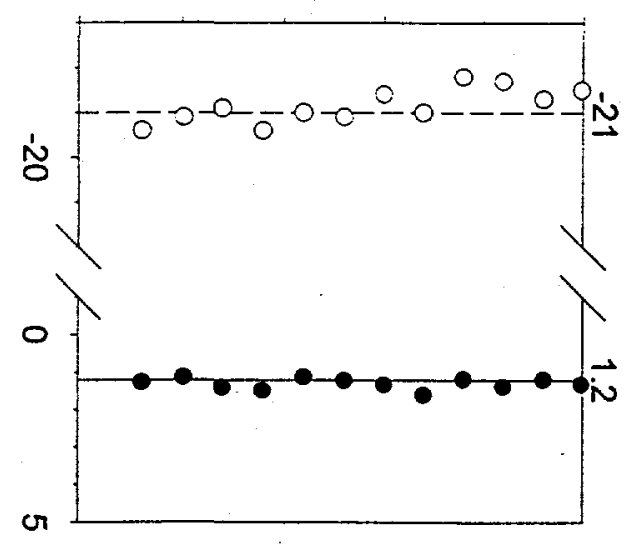

Depth (cm)
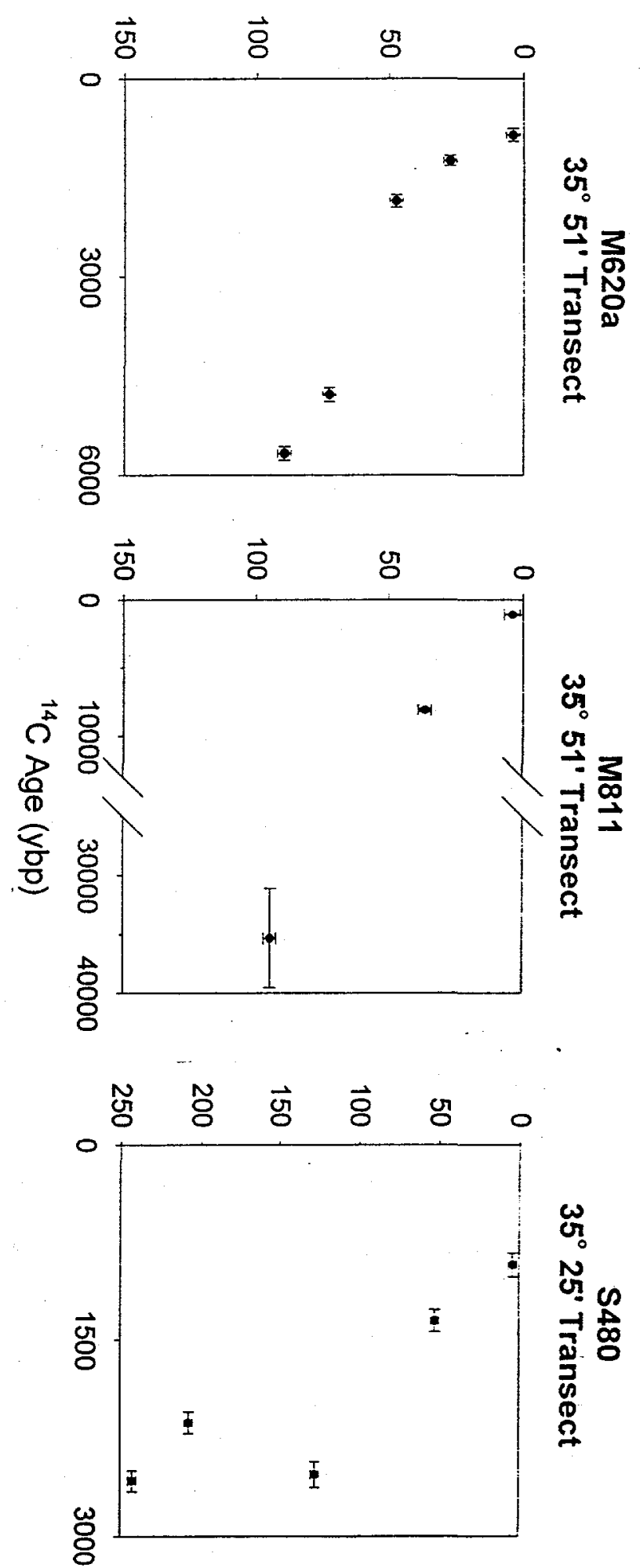
Depth (cm)

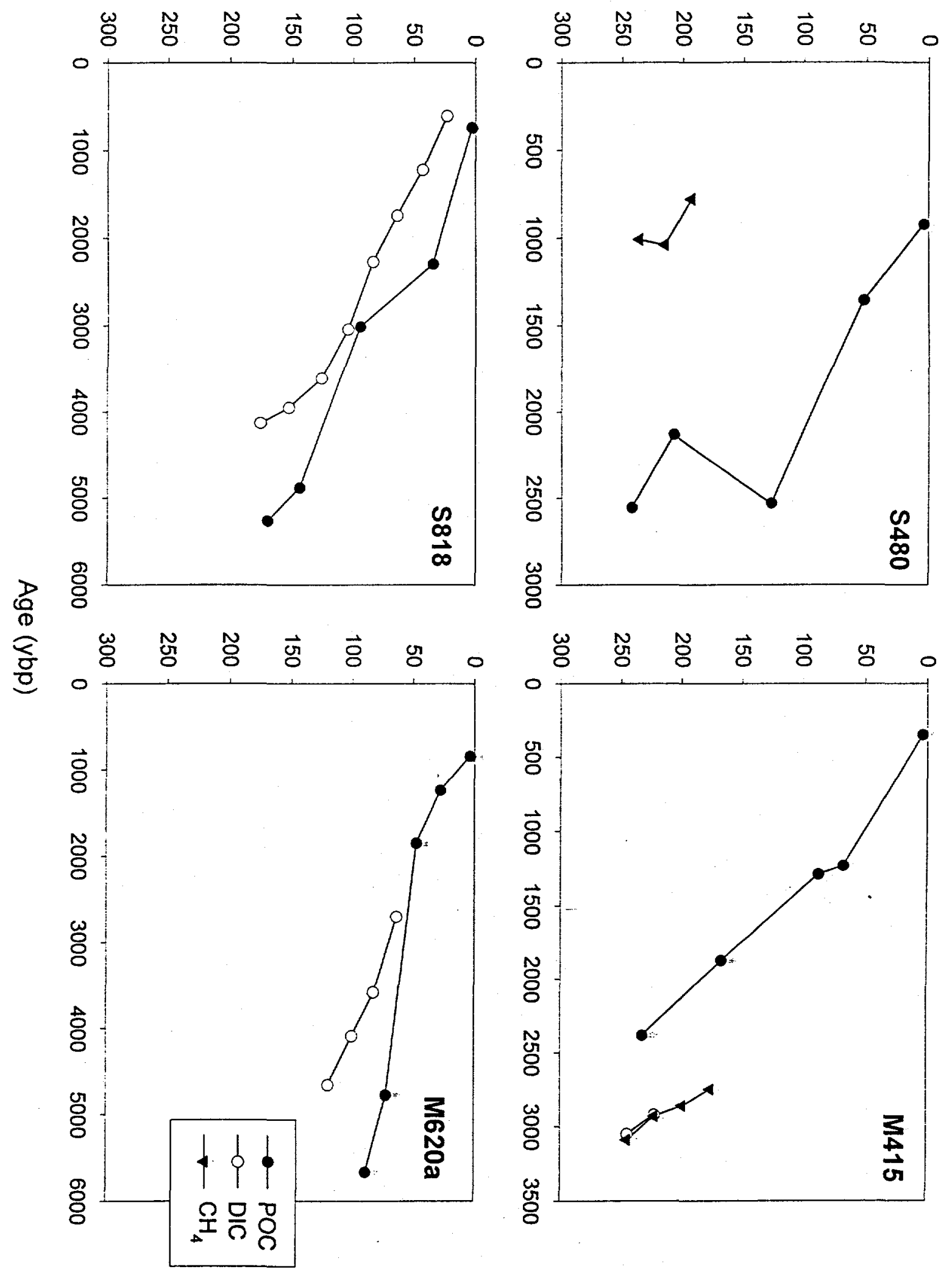



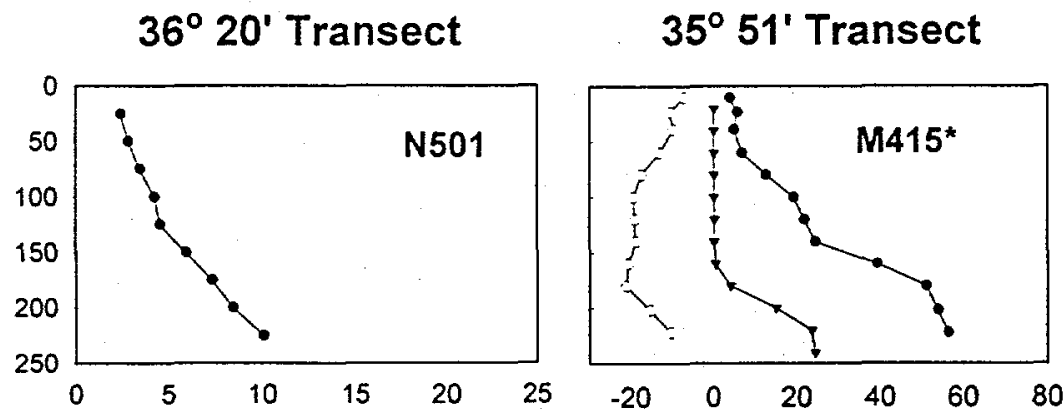

$35^{\circ} 25^{\prime}$ Transect
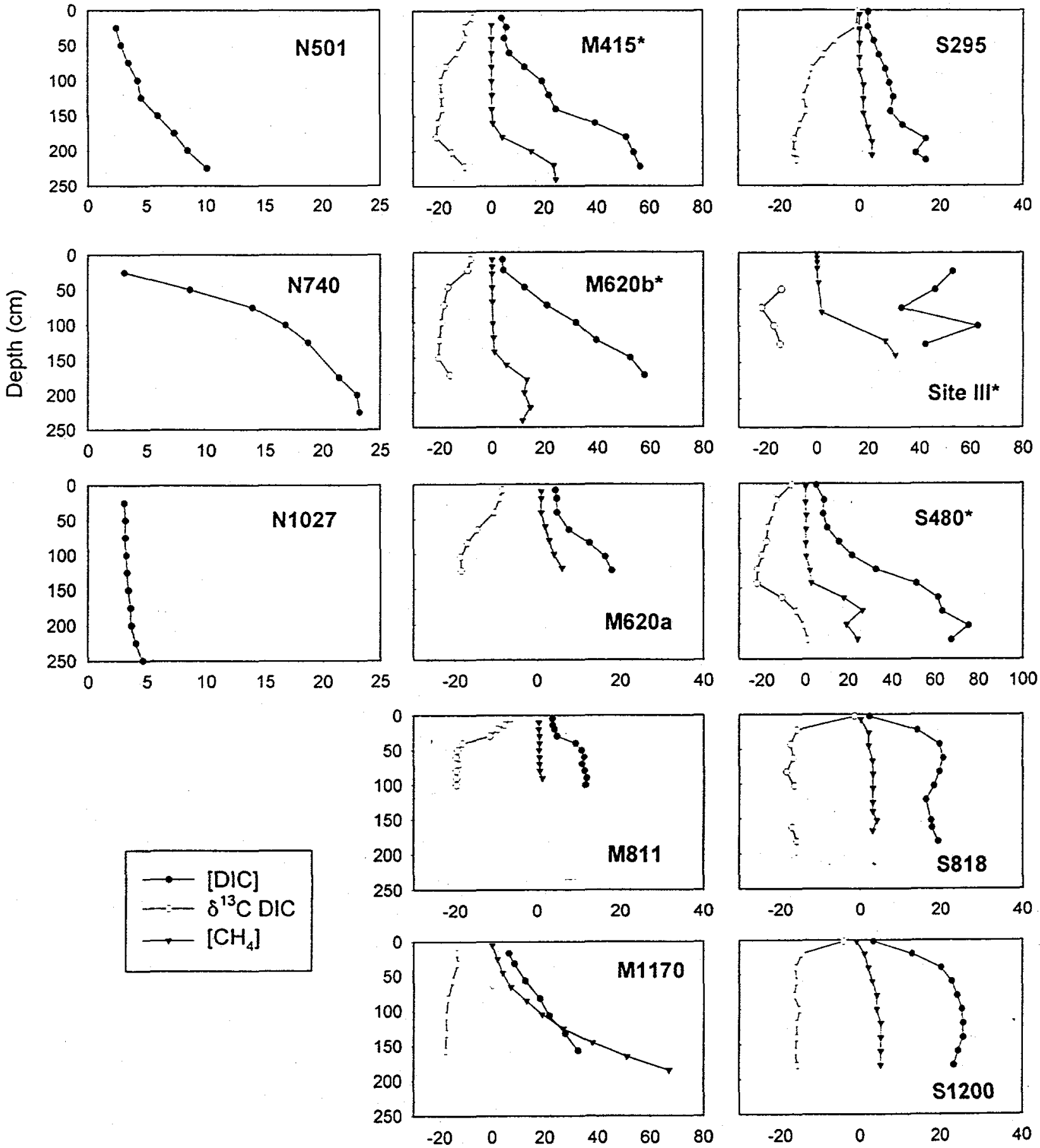

$\delta^{13} \mathrm{C} \mathrm{DIC},\left[\mathrm{CH}_{4}\right] \mu \mathrm{M}$, or [DIC] $\mathrm{mM}$ ${ }^{*}\left[\mathrm{CH}_{4}\right] \mu \mathrm{M} \times 10^{-2}$ 

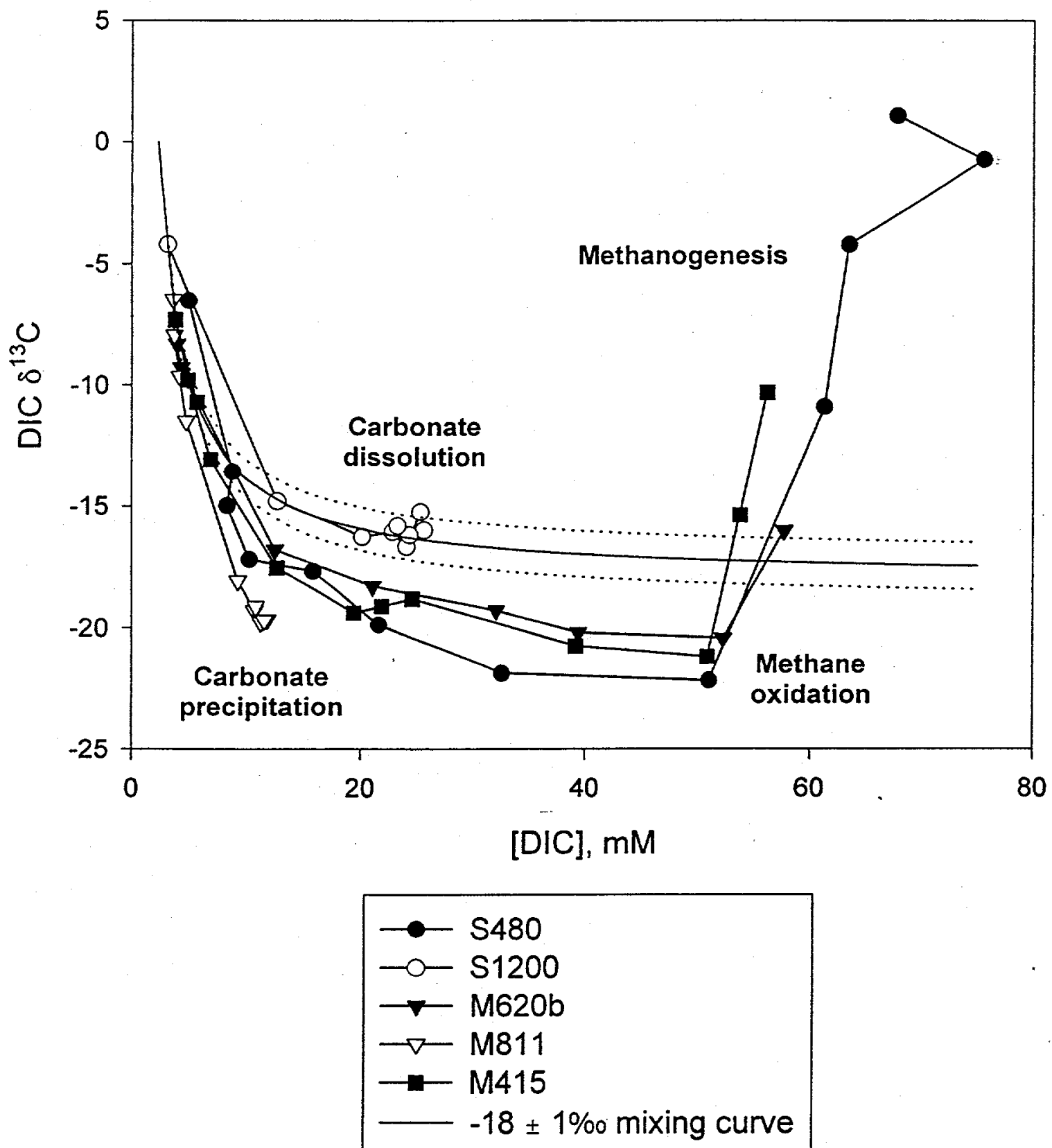
The biogeochemistry of carbon in continental slope sediments: the North Carolina margin

Neal Blair ${ }^{1}$, Lisa Levin ${ }^{2}$, David DeMaster ${ }^{1}$, Gayle Plaia ${ }^{1}$, Chris Martin $^{2}$, William Fornes ${ }^{1}$, Carrie Thomas $^{1}$ and Robin Pope ${ }^{1}$

${ }^{1}$ Department of Marine, Earth and Atmospheric Sciences, North Carolina State University,

Raleigh, NC 27695-8208

${ }^{2}$ Marine Life Research Group, Scripps Institution of Oceanography, La Jolla, CA 92093-0218

Submitted to the Proceedings of the 1998 Organism-Sediment Interactions

Symposium/Workshop, Belle Baruch Institute for Marine Biology and Coastal Research, University of South Carolina. 
1 Blair

Abstract

The responses of the continental slope benthos to organic detritus deposition were studied with a multiple tracer approach. Study sites were offshore of Cape Fear (I) and Cape Hatteras (III), NC (both $850 \mathrm{~m}$ water depth) and were characterized by different organic $\mathrm{C}$ deposition rates, macrofaunal densities (III $>\mathrm{I}$ in both cases) and taxa. Natural abundances ${ }^{13} \mathrm{C}$ and ${ }^{12} \mathrm{C}$ in particulate organic carbon (POC), dissolved inorganic carbon (DIC) and macrofauna indicate that the reactive organic detritus is marine in origin. Natural abundance levels of ${ }^{14} \mathrm{C}$ and uptake of ${ }^{13} \mathrm{C}$-labeled diatoms by benthic animals indicate that they incorporate a relatively young component of carbon into their biomass. ${ }^{13} \mathrm{C}$-labeled diatoms (Thalassiosira pseudonana) tagged with ${ }^{210} \mathrm{~Pb}$, slope sediment tagged with ${ }^{113} \mathrm{Sn}$ and ${ }^{228} \mathrm{Th}$-labeled glass beads were emplaced in plots on the seafloor at both locations and the plots were sampled after $30 \mathrm{~min}, 1-1.5 \mathrm{~d}$ and $14 \mathrm{mo}$. At Site I, tracer diatom was intercepted at the surface primarily by protozoans and surface-feeding annelids. Little of the diatom $\mathrm{C}$ penetrated below $2 \mathrm{~cm}$ even after 14 months. Oxidation of organic carbon appeared to be largely aerobic. At Site III, annelids were primarily responsible for the initial uptake of tracer. On the time scale of days, diatom $\mathrm{C}$ was transported to a depth of $12 \mathrm{~cm}$ and was found in animals collected between $5-10 \mathrm{~cm}$. The hoeing of tracer from the surface by the maldanid Praxillela sp. may have been responsible for some of the rapid nonlocal transport. Oxidation of the diatom organic carbon was evident to at least $10 \mathrm{~cm}$ depth. Anaerobic breakdown of organic matter is more important at Site III. Horizontal transport, which was probably biologically mediated, was an order of magnitude more rapid than vertical displacement over a year time scale. If the horizontal transport was associated with biochemical transformations of the organic matter it may represent an important but nearly invisible diagenetic process. 
2 Blair

Introduction

The deposition of organic carbon on the continental slope is an important component of the global and marine biogeochemical carbon cycles. Nearly $90 \%$ of the sedimentary inventory of organic carbon deposited during the Holocene resides on the slope and rise (Premuzic et al. 1982; Romankevich 1984; Walsh et al. 1985). Deposition is focused on the upper slope between 500-900 meters water depth (Martens 1987; Thomas 1998; Thomas et al. submitted). Approximately $26 \%$ of the anaerobic carbon oxidation in marine sediments occurs between 200 2000 meters as a result of the significant carbon flux to the slope even though the region represents only $9 \%$ of the seafloor surface (Henrichs and Reeburgh 1987). The detailed sources and fates of organic matter on the slope are poorly understood, but are of importance to understanding the roles of continental margins in historical and future changes in the global carbon cycle.

Considerable spatial heterogeneity exists in terms of sediment deposition and carbon cycling in this transitional environment between shallow and deep waters. Bathymetry ranges from gently sloping, nearly featureless bottoms to steep slopes that are cut with canyons, sometimes over small areas, such as on the North Carolina margin (Blair et al. 1994; DeMaster et al. 1994). Non-steady state deposition and mass wasting characterize the steep or incised environments (Thomas 1998; Thomas et al. submitted). Organic carbon depositional fluxes and benthic oxidation rates vary 1-2 orders of magnitude and $2-3 \times$ respectively over $100-\mathrm{km}$ scales (Anderson et al. 1994; Blair et al. 1994; DeMaster et al. 1994; Thomas 1998; Thomas et al. submitted). Benthic organism abundances and species compositions reflect those variations (Schaff et al. 1992). Accordingly, the pathways through which the carbon is processed are expected to vary as 
well.

The objective of this study was to elucidate the nature of and benthic responses to organic matter on the continental slope off North Carolina. We examine the sources and age of naturally occurring organic carbon in sediments and fauna, and with tracer experiments, examine particle mixing mechanisms and selectivity, carbon residence time, and the roles of benthic organisms in these processes. Comparisons are drawn between two continental slope locations with contrasting carbon depositional regimes and faunal assemblages. This paper represents a synthesis of work previously published by the authors and new data.

The study sites, I and III, are offshore of North Carolina in approximately 850 meters of water (Fig. 1). Site I $\left(32^{\circ} 52 \mathrm{~N}, 76^{\circ} 27 \mathrm{~W}\right)$ is $170 \mathrm{~km}$ southeast of Cape Fear, NC and has a gently sloping seafloor. Site III $\left(35^{\circ} 24 \mathrm{~N}, 74^{\circ} 50^{\prime} \mathrm{W}\right)$ is $61 \mathrm{~km}$ northeast of Cape Hatteras, NC. The region in the vicinity of Site III is extensively carved by small canyons and gulleys (Mellor and Paull 1994). The convergence of the Gulf Steam and Virginia Current offshore of Cape Hatteras focuses particulates into the Site III region producing an organic depositional flux that is 20-200 times greater than at Site I (DeMaster et al. 1994; Thomas 1998; Thomas et al. submitted). Macrofauna ( $2300 \mu \mathrm{m}$ ) are 2-6x more abundant at Site III as a result of the elevated food supply (Schaff et al. 1992; Levin et al. in press).

A multi-tracer approach was used in this study. Natural abundance levels of ${ }^{12} \mathrm{C},{ }^{13} \mathrm{C}$ and ${ }^{14} \mathrm{C}$ provided information about the sources and fates of the organic debris in the two environments. In addition, diatoms artificially enriched in ${ }^{13} \mathrm{C}(95 \%)$ along with radiotracer-tagged sediment and glass beads were used in situ to identify particulate and solute transport processes in the seabed, determine organic carbon oxidation rates and to identify the organisms responsible for 
the uptake and mixing of the diatomaceous material. The time scales of the in situ experiments ranged from 1 day to 14 months. The combined multi-tracer approach provided a novel view of the benthic carbon cycle on the continental slope. 
Methods

A particle mixture containing ${ }^{13} \mathrm{C}$ - and ${ }^{210} \mathrm{~Pb}$-labeled diatoms (freeze-dried onto kaolin), ${ }^{113} \mathrm{Sn}$-labeled local slope sediment $(10-60 \mu \mathrm{m}$ in size $)$, and ${ }^{228} \mathrm{Th}$-labeled glass beads (105-149 $\mu \mathrm{m}$ in size) was spread on the seafloor in August 1994 and October 1995 via submersible. Details concerning the multi-tracer methods are provided in Blair et al. (1996), Levin et al. (1997), and Fornes et al. (in press). Tracer particles were selected to represent a variety of natural particle types and sizes. The pelagic diatom, Thalassiosira pseudonana, was used because diatoms in this genus are found in surface sediments on the NC slope and beneath other upwelling regions (Cahoon et al. 1994). Subsurface sediment ( $>100$ years in burial age) collected near Site III was used to represent local sediment low in labile organic matter. Sand-sized particles (glass beads) also were chosen because they comprise approximately $32 \%$ of the naturally occurring sediment at the study site (Kelchner 1992).

Algae, slope sediment, and glass beads were tagged with $\gamma$-emitting tracers to permit rapid detection following core recovery from the seabed. In the case of the tagged diatom, the

${ }^{210} \mathrm{~Pb}$ also served as a conservative tracer to detect particle removal from the plots for the longer 14-month experiments. Experimental design avoided excessive organic carbon enrichment of sediments; labeled diatom carbon accounted for $<1.1 \%$ of existing POC levels $(1.2-1.7 \% \mathrm{C})$ in the upper $1 \mathrm{~cm}$ of sediment.

The tagged particles were spread in $40 \times 40 \mathrm{~cm}$ plots on the seafloor and then were sampled using Ekman boxcores within 30 minutes of tracer spreading ( $\mathrm{T}=0$ plots), after $\sim 1-1.5$ days or after 14 months. The Ekman boxcores $(15 \times 15 \times 15 \mathrm{~cm})$ each contained 4 subcores (a-d). Sediments within the subcores were analyzed for (a) $\delta^{13} \mathrm{C}$ of dissolved inorganic carbon (DIC) 
and particulate organic carbon (POC), (b) $\delta^{13} \mathrm{C}$ of infauna sorted on board ship then frozen, (c) radiotracers and glass beads, and (d) infaunal abundance and composition. Cores of background sediment were collected within $10 \mathrm{~m}$ of the plots for comparative purposes. All cores were stored on board ship at in situ temperature $\left(4-6^{\circ} \mathrm{C}\right)$ until they could be subsampled.

Sediment porewater was separated from the solid phase via centrifugation and the two fractions were stored frozen until analysis. One ml porewater samples were acidified, and the resulting $\mathrm{CO}_{2}$ was stripped with helium, dried via passage through magnesium perchlorate and Nafion ${ }^{\mathrm{TM}}$ tubing (Perma-Pure), and then trapped cryogenically for isotopic analysis. Subsamples of the centrifuged sediment were used for the $\mathrm{POC}$ analysis. $\mathrm{CO}_{2}$ for isotopic analysis was produced from the $\mathrm{POC}$ as described in Blair and Carter (1992). The ${ }^{13} \mathrm{C} /{ }^{12} \mathrm{C}$ content of the $\mathrm{CO}_{2}$ from both the DIC and POC was measured via isotope ratio mass spectrometry (Blair et al. 1996). Analyses of background cores were used to correct for the natural occurrence of ${ }^{13} \mathrm{C}$ (Blair et al. 1996). Concentrations are reported in terms of total $\mathrm{C}\left({ }^{13} \mathrm{C}+{ }^{12} \mathrm{C}\right)$ derived from the $95 \%$ ${ }^{13} \mathrm{C}$-labeled diatom.

Faunal samples for ${ }^{13} \mathrm{C}$ analysis were sorted from sediments retained on a $0.3 \mathrm{~mm}$ mesh screen, and then frozen at $-20^{\circ} \mathrm{C}$. Subcore sediments targeted for infaunal counts were sieved through a $0.3 \mathrm{~mm}$ screen and the animals retained were preserved in $8 \%$ buffered formalin and seawater (Levin et al., 1997).

In the laboratory, frozen animals were acidified with $1 \mathrm{~N} \mathrm{HCl}$ in silver boats and dried in vacuo. The samples were then treated in an identical fashion as the $P O C$ for ${ }^{13} \mathrm{C} /{ }^{12} \mathrm{C}$ analyses. Samples that were used for the determination of ${ }^{14} \mathrm{C}$-age were prepared similarly except that the $\mathrm{CO}_{2}$ produced by combustion was analyzed by accelerator mass spectrometer at the Lawrence 
Livermore Laboratory. Preserved specimens were sorted from sediments at 12 times magnification and identified to species, when necessary using a compound microscope with higher magnification.

$\gamma$-activities from the tracers were measured on wet sediment with an intrinsic germanium $\gamma-$ detector (DeMaster et al. 1994; Fornes et al. in press). The ${ }^{210} \mathrm{~Pb}$ and ${ }^{228} \mathrm{Th}$ activities in the experimental plots were corrected for naturally-occurring ${ }^{210} \mathrm{~Pb}$ and ${ }^{228} \mathrm{Th}$, based on profiles from background sediment cores. 
8 Blair

Results and Discussion

Sources of Organic Matter

The organic carbon concentrations of the surface sediments $(0-15 \mathrm{~cm}$ depth) average $1.2 \%$ and $1.7 \%$ on a dry weight basis for Sites I and III respectively (DeMaster et al. 1994). The bulk of the organic matter at both locations is marine in origin as indicated by the respective $\delta^{13} \mathrm{C}$ values of $-18.7 \pm 0.1 \%$ and $-21.2 \pm 0.1 \%$ (Blair et al. 1994). These values are characteristic of those found along the shelf and slope of the Eastern U.S. (Hunt 1966; Tanaka et al. 1991). The different ${ }^{13} \mathrm{C} /{ }^{12} \mathrm{C}$ compositions may be attributed to the mixing of marine and terrestrial sources with approximate end member $\delta^{13} \mathrm{C}$ values of $\sim-19 \pm 1 \%$ and $-26 \pm 2 \%$ (Hedges and Parker 1976; Fry and Sherr 1984).

The proximity of Site III to potentially major sources of terrigenous material, such as the Chesapeake Bay and the North Carolina sounds, is consistent with the difference in sedimentary ${ }^{13} \mathrm{C} /{ }^{12} \mathrm{C}$ compositions, as well as, reported elemental $\mathrm{C} / \mathrm{N}$ ratios (Site I - 7.5, Site III - 10; Blair et al. 1994). Lipid indicators of terrigenous organic matter have been identified in sediments from the Cape Hatteras slope near the Site III location (Harvey 1994). However, even though the evidence points towards a gradient in marine-terrestrial sources from Site I to III, we should not rule out the possibility that the isotopic difference originates, at least in part, from multiple marine sources with either varying species composition or diagenetic history (Gearing et al. 1984; Fry and Sherr 1984).

The sedimentary marine organic matter is a complex mixture, resulting from multiple sources. Microscopic analyses reveal planktonic and benthic diatoms and foraminifera, and seagrass fragments (Kelchner 1992; Cahoon et al. 1994; Levin et al. unpublished data). Lipid 
distributions of Cape Hatteras slope sediments suggest inputs from dinoflagellates and marine heterotrophs (Harvey 1994). The abundances of microbial and zooplankter lipids indicate extensive heterotropic recycling of the organic pool.

At Site III, particulate transport plays a role in determining the composition of the organic mix. The seaward deflection and convergence of the Gulf Stream and Virginia Current offshore of Cape Hatteras focus shelf-derived debris onto the slope (Csanady and Hamilton 1988; Walsh 1994; Blair et al. 1994; Thomas 1998; Thomas et al. in prep.). This material likely originates from a combination of terrestrial, estuarine and marine production and has been heterotrophically reworked during storage and/or transport on the shelf and upper slope. Delivery to the Site III seafloor appears to occur primarily via the slow settling of a dense suspension of flocculant snow punctuated by episodic lateral transport events (Hecker 1990; Blair et al. 1996). The complexity of the physics and geology in the Cape Hatteras area virtually guarantees that the organics are a mixture of partially reworked young and old materials.

The mechanisms of organic matter delivery to Site I are less well characterized. Downslope mass wasting should not be an important factor due to the gentle slope $\left(2-3^{\circ}\right.$; Schaff et al. 1992). In addition to local productivity, an additional source of material may be transport from the south via the Gulf Stream. Also, Gulf Stream meanders may entrain nearshore production from the west and transport it seaward to the site.

Particle Transport within the Seabed

Biological particle mixing rates are dramatically different at the two sites. The biodiffusion coefficients, $D_{b}$, estimated using naturally occurring excess ${ }^{234} \mathrm{Th}$ profiles in the seabed, were 
$0.3 \pm 0.1$ and $13 \pm 7 \mathrm{~cm}^{2} \mathrm{yr}^{-1}$ for Sites I and III respectively (Fornes 1996; Fornes et al. in press). Infaunal abundances and activities are potential controls on the $D_{b}$ values. Metazoan macrofaunal densities were nearly 3 times greater at Site III during the study period, which is consistent with past observations (Schaff et al. 1992; Blake and Grassle 1994; Fornes et al. in press; Levin et al., in press; Table 1). Macrofauna appeared to be distributed deeper at Site III. Of the approximately 25,000 individuals $\mathrm{m}^{-2}$ counted in 1994-95 at Site III, about $15 \%$ were found below $5 \mathrm{~cm}$ (Fornes et al. in press; Levin et al. in press). In contrast, $8 \%$ of 9,000 individuals $\mathrm{m}^{-2}$ were collected from below $5 \mathrm{~cm}$ at Site I. Polychaetes were the dominant metazoan macrofaunal taxon at both sites though the major polychaete taxa differed between Sites I and III (Table 1; Schaff et al. 1992; Levin et al., in press). Agglutinated protozoa (foraminifera and xenophyophores) were common at both sites yet were slightly more abundant and much more diverse at Site I (Hughes 1996; Gooday, pers. comm.). Larger infauna (megafauna) were not quantified by our Ekman cores, but also may be important bioturbators.

The artificial multi-tracer mixture containing ${ }^{13} \mathrm{C}$-labeled Thalassiosira pseudonana, tagged sediment and glass beads was emplaced in plots at both sites to determine how the particle mixing processes might vary. At Site I, little ${ }^{13} \mathrm{C}$-tracer was detected below $1 \mathrm{~cm}$ depth in the seabed in the $T=0$ controls $(4 \pm 5 \%, n=5$ for $1994-95)$ and the $T=1,1.5$ d plots $(4 \pm 5 \%, n=6 ;$ Fig. 2$)$. The tagged sediment and glass beads exhibited parallel behaviors (Fornes 1996; Fornes et al. in press). The similarities between the $T=0$ and $T=1,1.5 \mathrm{~d}$ plots indicate that passive settling of tracer down burrows and tubes and artifacts associated with the experimental procedure cannot be discounted as an important mode of delivery of the tracers below $1 \mathrm{~cm}$ in those experiments. Evidence for biologically mediated transport was observed in a portion of a $1.5 \mathrm{~d}$ plot that was subsampled for 
the $\gamma$-emitter measurements. In that subcore, subsurface peaks of ${ }^{210} \mathrm{~Pb}$ (tagged diatom) and ${ }^{113} \mathrm{Sn}$ (sediment) were observed at $3-5 \mathrm{~cm}$ that accounted for $2 \%$ and $0.4 \%$ of the total respective inventories (Fig. 3). The transport appears to have been selective for the diatom as indicated by the ${ }^{210} \mathrm{~Pb} /{ }^{113} \mathrm{Sn}$ ratios for the peak $(24 \pm 8)$ and the total core $(5 \pm 0.2)$.

After 14 months, $4.1 \pm 3.6 \%$ ( $n=3$; Fig. 4 ) of the ${ }^{13}$ C-tracer remained in the plots. Loss from the plot occurred by both in situ oxidation or horizontal transport. The relative importance of those two processes was resolved using the inventory of diatom-tagged ${ }^{210} \mathrm{~Pb}$. The portion of tracer ${ }^{210} \mathrm{~Pb}$ remaining after $14 \mathrm{mo}, 10 \pm 8.6 \%$, indicates that approximately $90 \%$ of the diatom may have been lost via horizontal transport if it is assumed that the ${ }^{13} \mathrm{C}$ and ${ }^{210} \mathrm{~Pb}$ tracked each other reasonably well. The mode of horizontal removal could have been either biological or physical. We currently do not have a means to distinguish between the two at this site.

The bulk of the tracer that remained in the plots at Site I after 14 mo was sequestered in the upper $2 \mathrm{~cm}$ of the seabed. Transport below that depth was minimal with the exception of the creation of a subsurface peak centered at $6 \mathrm{~cm}$ in one subcore. In summary, bioturbation over time scales of days to one year at this site is best characterized by slow diffusive mixing of particles coupled with an occasional nonlocal advective transfer of material to depths of $3-6 \mathrm{~cm}$ (Fornes et al. in press).

Mixing occurred more rapidly and deeper at Site III. In the $\mathrm{T}=0$ control plots, $\leq 2 \%$ of the ${ }^{13} \mathrm{C}$-labeled diatom was found below $2 \mathrm{~cm}$ (Fig. 2). In contrast, 7-17\% of the diatom tracer was found below $2 \mathrm{~cm}$ in the two $\mathrm{T}=1.5 \mathrm{~d}$ plots. Multiple subsurface peaks were observed with the most prominent occurring at $10-12 \mathrm{~cm}$. The tagged glass beads and sediment exhibited similar distributions (Levin et al. 1997; Fornes et al. in press). 
The whitish tracer mixture was observed at the base of a maldanid tube (Praxillella sp.) at $13 \mathrm{~cm}$ depth in one $\mathrm{T}=1.5 \mathrm{~d}$ subcore. The individual in the tube had not ingested the tracer (as indicated by its $\delta^{13} \mathrm{C}$ value) which suggests that the tracer was hoed to depth by this head-down deposit feeder (Levin et al. 1997). Shallow-water members of the same subfamily (Euclyminae) appear to drag fresh surface material down their tube into the feeding cavity as well (Mangum 1964; Kudenov 1978; Weinberg 1978; Dobbs and Whitlach 1982). The ratios of tagged diatom, sediment and glass beads indicates that the transport process was nonselective for the tracer particle types (Fornes 1996; Fornes et al. in press; Levin et al. in press).

Shallower subsurface peaks in tracer concentration were observed in these (Fig. 2) and previous in situ experiments using ${ }^{13} \mathrm{C}$-Chlorella at this site (Blair et al. 1996). The transport processes that created the peaks were not significantly selective for any of the particle types in the tracer mixture (Fornes et al. in press). The animals responsible for the movement of tracer to depths of 2-6 cm have not been positively identified. Based on ${ }^{13} \mathrm{C}$-incorporation (see below), faunal vertical distributions within the sediment, and the construction of distinct tube and burrow systems that might serve as repositories of tracer, candidates for the nonlocal transport include the polychaete Scalibregma inflatum, Aricidea quadrilobata, several species of maldanids, and the nereid Ceratocephale loveni (Blair et al. 1996).

The ${ }^{13} \mathrm{C}$-diatom organic matter and other tracers were largely lost from the plots at Site III after 14 months. The portions of ${ }^{13} \mathrm{C}$ and ${ }^{210} \mathrm{~Pb}$ remaining were $0.9 \pm 0.5 \%$ and $1.7 \pm 0.9 \%$ respectively and were distributed to at least $8 \mathrm{~cm}$ depth (Fig. 4). Biological removal is suspected because of the extensive tracks and trails on the sediment surface. Certain demersal fish species, such as the eelpout Lysenchelys verrilli, have population densities nearly an order of magnitude 
higher on the middle slope of Cape Hatteras than adjacent slope regions possibly as a result of abundant infaunal prey (Hecker 1994). These same predators may be responsible for rapid horizontal particulate transport. For example, eelpout were observed wallowing in plots shortly after tracer emplacement. Flags and stakes marking some 14-mo plots were pushed out radially from the center suggesting disturbance from within the plot as opposed to a unidirectional movement across plots as might be expected by a physical process.

Initially vertical particle mixing at Site III was primarily nonlocal in nature but it took on a diffusive appearance over time scales of weeks to months (Blair et al. 1996; Fornes et al. in press). At the same time, large, surface-dwelling deposit feeders and predators competed for the newly deposited material and moved it laterally. Rapid vertical transport provides a means for subsurface organisms to deal with the competitive pressures on the surface for the same food resources (Jumars et al. 1990) and may be critical for the support of the subsurface ecosystem (Levin et al. 1997).

Organic carbon uptake, assimilation and oxidation in the seabed

The natural abundances of ${ }^{12} \mathrm{C},{ }^{13} \mathrm{C}$, and ${ }^{14} \mathrm{C}$ provide information concerning the source of the organic carbon that is assimilated into benthic biomass. The $\delta^{13} \mathrm{C}$ of annelids $(-16.5 \pm 0.3 \%$, $\mathrm{n}=16)$, non-annelid metazoans $(-18.2 \pm 0.6 \%, \mathrm{n}=7)$ and agglutinating protozoans $(-18.7 \pm 0.2 \%$, $\mathrm{n}=25$ ) at Site I were the same as, or more positive than that of the sedimentary organic matter (Levin et al. in press) in background (non -experimental) sediments. The isotopic composition of the protozoans likely reflects in part the carbon associated with their tests of sediment particles. The ${ }^{13} \mathrm{C}$-enrichment exhibited by the metazoans relative to the bulk sediment may have been the 
14 Blair

result of either the selective incorporation of an organic fraction from the sedimentary pool or a metabolic isotope effect by the animal itself (Hentschel 1998; Levin et al. in press). All of the $\delta^{13} \mathrm{C}$ values indicated a diet dependent on marine organic sources (Fry and Sherr 1984).

Similar patterns existed at Site III. Annelid, non-annelid and agglutinated protozoan $\delta^{13} \mathrm{C}$ values were $-19.0 \pm 0.2 \%(n=30),-19.8 \pm 0.8 \%(n=8)$ and $-20.0 \pm 0.1 \% 0(n=5)$ respectively. These values were comparable to that of the metabolizable organic fraction, -18\%, estimated from DIC production and fluxes (Thomas 1998; Thomas et al. submitted).

Natural ${ }^{14} \mathrm{C}$ abundances of animals from the Cape Hatteras slope indicated clearly that young organic matter was preferentially incorporated into biomass (Table 2). All animals, ranging from the demersal eelpout to subsurface-dwelling annelids, had modern ${ }^{14} \mathrm{C}$ ages despite a $\geq 900$ year age of the surface organic matter. Particle discrimination, possibly by feeding on young surficial floc, and the selective incorporation of biochemically recognizable fractions may have contributed to the young ages.

Some of the macrofauna that first accessed recently deposited organic matter have been identified by their elevated ${ }^{13} \mathrm{C}$-content following the 1 to 2 day exposure to the tracer diatoms. Approximately $60 \%$ of the agglutinated protozoan and annelid specimens collected in the $1-1.5 \mathrm{~d}$ experiments had ${ }^{13} \mathrm{C}$-contents in large excess of that found in the $\mathrm{T}=0$ controls (Fig. 5; Levin et al. in press). Non-annelid metazoans (molluscs, crustaceans and other taxa) incorporated far less tracer on average. Surface-deposit feeding annelids were important consumers of the tracer, whereas subsurface-deposit feeders and carnivores were not (Levin et al.,in press). Both annelids and protozoans retained significant levels of diatom carbon 14 months after tracer emplacement with annelids apparently retaining more (Fig. 5). The tracer $\mathrm{C}$ was distributed through surface- 
and subsurface-deposit feeding as well as carnivorous annelids.

Annelids were the primary consumers of tracer in the $1.5 \mathrm{~d}$ treatments at Site III (Fig. 5; Levin et al. in press). Over $60 \%$ of the individuals collected for isotope analysis from the $1.5 \mathrm{~d}$ plots were ${ }^{13} \mathrm{C}$-enriched. Aricidea spp. and maldanids consumed the most diatom tracer (Table 3 ). The tracer ${ }^{13} \mathrm{C}$ was retained in some species (e.g. Ceratocephale loveni, Levinsenia and Cossura sp.) after 14 months, though levels were considerably lower than at Site I. The between-site difference in retention reflects the greater loss of tracer from the Site III plots via horizontal transport.

Oxidation of the ${ }^{13} \mathrm{C}$-labeled diatom led to the accumulation of dissolved inorganic ${ }^{13} \mathrm{C}$ $\left(\mathrm{DI}^{13} \mathrm{C}\right.$ ) in the sediment pore water at both sites (Fig. 6). At Site I oxidation occurred principally at the surface and the $\mathrm{DI}^{13} \mathrm{C}$ appeared to diffuse into the seabed. Application of a reactiontransport model (see Appendix) verified that observation and indicated that solute transport is dominated by molecular diffusion. Bioirrigation was not a significant factor at Site I.

The oxidation of organic carbon is typically treated as a pseudo-first order process (Berner 1980). The rate coefficient, $\mathrm{k}$, is dependent on molecular structure (de Leeuw and Largeau 1993), sample matrix (e.g. diatom frustules, clay aggregates; Burdige and Martens 1988; Hedges and Keil 1995; Cowie and Hedges 1996), age (Middelburg 1989) and environment (Cowie and Hedges 1991; Sun et al. 1993; Canfield 1994). In the in situ experiments, time was required for the colonization of the newly emplaced tracer, thus $\mathrm{k}$ should have increased with time until a maximum value is reached. The fit of the model output to the data was improved by the inclusion of a time-dependent $\mathrm{k}$. Examples of potential trajectories of $\mathrm{k}$ as a function of time are depicted in Figure 7. The apparent rate coefficients increased to realistic values $\left(\sim 10-20 \mathrm{yr}^{-1}\right.$; 
Westrich and Berner 1984) in less than two days. Values $>50 \mathrm{yr}^{-1}$ may have been attained for a short period after $1.5 \mathrm{~d}$ as the very labile fractions were oxidized (Westrich and Berner 1984; Henrichs and Doyle 1986). After the most reactive or accessible components in the diatom matrix were consumed, $\mathrm{k}$ would have decreased with time. Based on the apparent oxidative loss from the long term plots, the 14-mo average value of $\mathrm{k}$ was $\sim 1 \mathrm{yr}^{-1}$, which is consistent with laboratorybased algal degradation experiments (1-7 $\mathrm{yr}^{-1}$; Garber 1984; Westrich and Berner 1984).

$\mathrm{DI}^{13} \mathrm{C}$ penetration into the seabed was deeper at Site III (Fig. 6). Coincident subsurface peaks in $\mathrm{PO}^{13} \mathrm{C}$ and $\mathrm{DI}^{13} \mathrm{C}$ centered near $10 \mathrm{~cm}$ indicated that the $\mathrm{DI}^{13} \mathrm{C}$ found deep was the result of the oxidation of subducted diatom tracer. Much of the subsurface oxidation of organic carbon was anoxic as suggested by the natural abundances of ${ }^{13} \mathrm{C}^{12} \mathrm{C}$ in the background DIC pool (Blair et al. 1994). If the fate of the diatom tracer was characteristic of what happens to natural detrital falls then the subduction activities of macrofauna at this site play a significant role in determining the aerobic/anaerobic exposure history of reactive organic matter. This in turn will influence the pathways and rates of organic diagenesis and the resulting geochemical record.

The reaction-transport model along with background DIC pore water profiles, indicated irrigation is an important solute transport process at Site III. The model output also suggested that either irrigation rates were higher at the surface than in the subsurface, or $k$ was larger for subducted material. The former scenario is plausible because infaunal densities decrease with depth (Levin et al. in press). Aller (1988) discussed the relationship between burrow density and irrigation intensity. Subduction of newly deposited organic matter may have increased $\mathrm{k}$ by mixing the material with sediment and thus providing an inoculum for microbial degradation. The relative importance of the two scenarios has not been determined. 
17 Blair

Summary and Conclusions

The physical oceanography of the North Carolina continental slope leads to the deposition of organic detritus that is complex in composition. The detritus is predominantly marine in origin and much of it has been recycled heterotrophically. Components of the organic mixture are modern to greater than 900 years in age. The range in age is possibly due to differential storage on the shelf and upper slope. The youngest material is preferentially incorporated into the benthic biomass presumably because it alone is biochemically recognizable by organisms for anabolic processes.

How the benthos react to the deposition of organic detritus appears to be linked to the average rate of deposition. Organic matter deposited in an environment that normally receives a slow particulate flux tends to be consumed aerobically on or near the sediment surface. Agglutinating protozoans and surface-feeding annelids are the primary macrofaunal consumers of phytodetritus shortly after deposition. Non-local transport of material to the subsurface occurs sporadically. Microbial colonization of the deposited material occurs over the time scale of days.

Organic matter falling on a seabed that is characterized by rapid particle deposition is rapidly mixed into the seabed and much of it is decomposed anaerobically. Offshore of Cape Hatteras, nonlocal transport of material down to $>10 \mathrm{~cm}$ by annelids is a frequent phenomenon and may be an important source of food for subsurface-feeding animals and the anaerobic ecosystem.

At least an order of magnitude more material was moved horizontally across the sediment surface than vertically into the seabed over a year's period. If the horizontal transport is largely physical in nature or associated with faunal locomotion, the most obvious impact on the carbon 
biogeochemistry will be the homogenization of the surface sediments. On the other hand, if transport is the consequence of ingestion and egestion, it could represent a significant, yet virtually invisible, diagenetic process. The importance of horizontal transport on the organic geochemical record merits further investigation.

The interrelationship between sedimentary organic carbon and the benthos is complex. The character and depositional flux of organic carbon have a profound influence on faunal composition and density. At the same time, the characteristics of the benthic organisms control the fate of the organic matter after deposition. Thus, the resulting molecular organic record and the organic carbon flux are linked. Characterization of that linkage awaits future studies of organism-sediment interactions.

\section{Acknowledgments}

The skilled contributions of the crews, pilots and captain of the R/V Edwin Link and Johnson SeaLink were essential for this project. We thank the many participants of the SLOPEX cruises, which includes D. Beauregard, S. Boehme, E. Clesceri, R. Collman, J. Crooks, D. Daley, C. DiBacco, D. Dinsmore, A. McCray, T. Pease, C. Reimers, W. Savidge, and D. Talley, for their technical assistance. D. Albert, R.C. Aller, L. Benninger, M. Alperin, R. Jahnke and C.S. Martens were of great assistance during the DOE Ocean Margins Program portion of this research. This research was supported by grants from the NOAA National Undersea Research Program at Wilmington, NC, the National Science Foundation (OCE 93-11711 and 93-01793), and the Department of Energy (DE-FG05-95ER62082). 
19 Blair

Appendix

A reaction-transport model that employs nonlocal as well as diffusive mixing was used to simulate ${ }^{13} \mathrm{C}$-labeled diatom movement and oxidation in the seabed. Portions of this model have been used to reproduce subsurface profiles of ${ }^{13} \mathrm{C}$-labeled Chlorella emplaced in situ on NC slope sediments (Blair et al. 1996), and ${ }^{13} \mathrm{C}$-labeled diatoms in laboratory experiments using slope and shelf sediments (Thomas 1998). The model describes the distribution of tracer in two pools: the instantaneously deposited surface layer and the subsurface distribution. The concentration of $\mathrm{PO}^{13} \mathrm{C}$ in the deposited tracer layer, $\mathrm{C}_{\mathrm{o}}(0 \leq \mathrm{x} \leq \epsilon)$, is described by:

$$
\frac{\partial C_{o}}{\partial t}=\frac{\partial}{\partial x}\left(D_{b} \frac{\partial C_{o}}{\partial x}\right)-[k+\underline{R}] C_{o}
$$

where:

$$
\begin{aligned}
& C=\text { concentration of } \mathrm{PO}^{13} \mathrm{C}\left(\mu \text { moles }{ }^{13} \mathrm{C} \mathrm{cm}^{-3}\right), \\
& t=\text { time }(\mathrm{yr}), \\
& x=\text { depth in sediment }(\mathrm{cm}), \\
& D_{b}=\text { biological mixing coefficient }\left(\mathrm{cm}^{2} \mathrm{yr}^{-1}\right), \\
& k=\text { first order decay constant for the diatom }\left(\mathrm{yr}^{-1}\right), \\
& R=\text { nonlocal transport removal term }\left(\mathrm{yr}^{-1}\right), \text { and } \\
& \epsilon=\text { thickness of the tracer layer }(1 \mathrm{~mm}) .
\end{aligned}
$$

Removal of tracer from the surface layer is assumed to be first order with respect to surface 
concentration and to be unidirectional. It is also assumed that the $1 \mathrm{~mm}$ thick tracer layer remains well-mixed and that deposit feeding is depth independent within the layer. The concentration profile of $\mathrm{PO}^{13} \mathrm{C}$ below the tracer layer $(\epsilon \leq \mathrm{X} \leq \mathrm{L})$ was simulated using:

$$
\frac{\partial C}{\partial t}=\frac{\partial}{\partial x}\left(D_{b} \frac{\partial C}{\partial x}\right)-k C+s_{x} \bar{C}_{o}
$$

where:

$$
\begin{aligned}
& \mathrm{L}=\text { depth of sediment in the flux chamber }(\mathrm{cm}), \\
& \bar{C}_{0}=\frac{1}{\epsilon} \int_{0}^{\epsilon} C_{o} d x \\
& s_{x}=\text { nonlocal transport supply term }\left(\mathrm{yr}^{-1}\right)
\end{aligned}
$$

Where there are multiple subsurface peaks, the nonlocal removal term, $\underline{R}$, is given by:

$$
\underline{R}=\sum_{x=1}^{n} r_{x}
$$

where $n$ is the number of peaks. For any given peak, the nonlocal supply term, $s_{x}$ is related to $r_{x}$ by:

$$
\int_{0}^{\epsilon} r_{x} d x=\int_{x_{i}}^{x_{j}} s_{x} d x
$$


Equations 1 and 2 were solved numerically with an explicit finite difference method. The two equations were coupled by the nonlocal transport term, $s_{x} \bar{C}_{o}$, and the boundary condition described in $6 \mathrm{~b}$, which establishes conservation of tracer flux across the interface at $x=\epsilon$. Boundary conditions for the solutions were:

$$
\begin{array}{ll}
\partial C_{o} / \partial x=0 & x=0 \\
\partial C_{o} / \partial x=\partial C / \partial x & x=\epsilon \\
\partial C / \partial x=0 & x=L .
\end{array}
$$

The reaction portion of the model simulated $\mathrm{DI}^{13} \mathrm{C}$ production in the surface tracer layer and subsurface porewater pools. The concentration of $\mathrm{DI}^{13} \mathrm{C}$ oxidatively produced was simulated using:

$$
\frac{\partial\left[D I^{13} C\right]}{\partial t}=D_{0} \frac{\partial \Phi}{\partial x}\left(\frac{\partial\left[D I^{13} C\right]}{\partial x}\right)+k C
$$

where:

$D_{s}=D_{o} \times \Phi^{2}$ (Ullman and Aller 1982)

$D_{o}=$ temperature/viscosity corrected free solution diffusivity of $\mathrm{HCO}_{3}^{-}$

$\Phi=$ sediment porosity.

At time zero, the concentration of $\mathrm{DI}^{13} \mathrm{C}$ in both the sediment and overlying water was set at zero. The overlying water was assumed to be well-mixed, and the only source of $\mathrm{DI}^{13} \mathrm{C}$ to the 
overlying water was the flux out of the sediment. All model profiles were integrated over $1 \mathrm{~cm}$ intervals to facilitate comparison with data. Time steps of 0.1 hours were adequate to maintain stability and deal with stiffness. 


\section{Literature Cited}

Aller, R.C. 1988. Benthic fauna and biogeochemical processes in marine sediments: The role of burrow structures, p. 310-338. In T.H. Blackburn and J. Sorensen (eds.) Nitrogen Cycling in Coastal Marine Environments. J. Wiley and Sons, New York.

Anderson R F., G.T. Rowe, P.Kemp, S. Trumbore, and P.E. Biscaye. 1994. Carbon budget for the mid-slope depocenter of the Mid-Atlantic Bight. Deep-Sea Research II 41: 669-703.

Berner, R.A. 1980. Early Diagenesis: A Theoretical approach. Princeton University Press, Princeton, NJ.

Blair, N.E. and W.D. Carter, Jr. 1992. The carbon isotope biogeochemistry of acetate from a methanogenic marine sediment. Geochimica Cosmochimica Acta 56: 1247-1258.

Blair, N.E., G. R. Plaia, S.E. Boehme, D.J. DeMaster, and L.A. Levin. 1994. The remineralization of organic carbon on the North Carolina continental slope. Deep-Sea Research II 41: 755-766.

Blair, N.E., L.A. Levin, D.J. DeMaster and G. Plaia. 1996. The short-term fate of fresh algal carbon in continental slope sediments. Limnology and Oceanography 41: 1208-1219. 
Blake, J.A. and J.F. Grassle. 1994. Benthic community structure on the U.S. South Atlantic slope off the Carolinas: Spatial heterogeneity in a current dominated system. Deep-Sea Research 41: 834-874.

Burdige, D.J. and C.S. Martens. 1988. Biogeochemical cycling in an organic-rich coastal marine basin: 10. The role of amino acids in sedimentary carbon and nitrogen cycling. Geochimica et Cosmochimica Acta 52: 1571-1584.

Cahoon, L.B., R.A. Laws and C.J. Thomas. 1994. Viable diatoms and chlorophyll a in continental slope sediments off Cape Hatteras, North Carolina. Deep-Sea Research II 41: 767-782.

Canfield, D.E. 1994. Factors influencing organic carbon preservation in marine sediments. Chemical Geology 114: 315-329.

Cowie, G.L. and J.I. Hedges. 1991. The role of anoxia in organic matter preservation in coastal sediments: Relative stabilities of the major biochemicals under oxic and anoxic depositional conditions. Advances in Organic Geochemistry 19: 229-234.

Cowie, G.L. and J.I. Hedges. 1996. Digestion and alteration of the biochemical constituents of a diatom (Thalassiosira weissflogii) ingested by an herbivorous zooplankton (Calanus pacificus). Limnology and Oceanography 41: 581-594. 
Csanady, G.T. and P. Hamilton (1988) Circulation of slopewater. Continental Shelf Research 8: $565-624$.

de Leeuw, J.W. and C. Largeau. 1993. A review of macromolecular organic compounds that comprise living organisms and their role in kerogen, coal and petroleum formation, p. 23-72. In M.H. Engel and S.A. Macko (eds.) Organic Geochemistry - Principles and Applications. Plenum Press, New York.

DeMaster, D.J., R.H. Pope, L.A. Levin and N.E. Blair. 1994. Biological mixing intensity and rates of organic carbon accumulation in North Carolina slope sediments. Deep-Sea Research II 41: 735-753.

Dobbs, F.C. and R.B. Whitlach. 1982. Aspects of deposit-feeding by the polychaete Clymenella torquata. Ophelia 21: 159-166.

Fornes, W.L. 1996. Bioturbation and particle transport in Carolina slope sediments: a radiochemical approach. M.S. thesis. North Carolina State University, Raleigh, NC.

Fornes, W.L., D.J. DeMaster, L.A. Levin and N.E. Blair. In press. Bioturbation and particle transport in Carolina slope sediments: a radiochemical approach. Journal of Marine Research. 
Fry, B. and E.B. Sherr. $1984.8^{13} \mathrm{C}$ measurements as indicators of carbon flow in marine and freshwater ecosystems. Contributions in Marine Science 27: 13-47.

Garber, J.H. 1984. Laboratory study of nitrogen and phosphorus remineralization during the decomposition of coastal plankton and seston. Estuarine Coastal Shelf Science 18: 685-702.

Gearing, J.N., P.J. Gearing, D.T. Rudnick, A.G. Requejo and M.J. Hutchins. 1984. Isotopic variability of organic carbon in a phytoplankton-based temperate estuary. Geochimica et Cosmochimica Acta 48: 1089-1098.

Harvey, H.R. 1994. Fatty acids and sterols as source markers of organic matter in sediments of the North Carolina continental slope. Deep-Sea Research 41: 783-796.

Hecker, B. 1990. Photographic evidence for the rapid flux of particles to the sea floor and their transport down the continental slope. Deep-Sea Research 37: 1773-1782.

Hedges, J.I. and R.G. Keil 1995. Sedimentary organic matter preservation: an assessment and speculative synthesis. Marine Chemistry 49: 81-115.

Hedges, J.I. and P.L. Parker. 1976. Land-derived organic matter in surface sediments from the Gulf of Mexico. Geochimica et Cosmochimica Acta 40: 1019-1029. 
Hentschel, B. 1998. Intraspecific variations in $\delta^{13} \mathrm{C}$ indicate ontogenetic diet changes in depositfeeding polychaetes. Ecology 79: 1357-1370.

Henrichs, S.M. and A.P. Doyle. 1986. Decomposition of 14C-labeled organic substances in marine sediments. Limnology and Oceanography 31: 765-778.

Henrichs, S. M. and W. S. Reeburgh. 1987. Anaerobic mineralization of marine sediment organic matter: Rates and the role of anaerobic processes in the oceanic carbon economy.

Geomicrobiology Journal 5: 191-237.

Hughes, J.A. 1996. Benthic foraminiferal assemblages on the North Carolina continental slope. MSc. thesis, University of Southhampton.

Hunt J.M. 1970. The significance of carbon isotope variations in marine sediments, p. 27-35. In G.D. Hobson and G.C. Speers (eds. ) Advances in Organic Geochemistry, 1966, Pergamon Press, Oxford.

Jumars, P.A., L.M. Mayer, J.W. Deming, J.A. Baross, and R.A. Wheatcroft. 1990. Deep-sea deposit-feeding strategies suggested by environmental and feeding constraints. Philosophical Transactions of the Royal Society of London Series A 331: 85-101. 
Kelchner, C. 1992. Organic-rich depositional regimes, North Carolina continental slope:

Evaluating source sites and sediment transport pathways. M.S. thesis, North Carolina State University, Raleigh, NC.

Kudenov, J.D. 1978. The feeding ecology of Axiothella rubrocincta (Johnson) (Polychaeta: Maldanidae). Journal of Experimental Marine Biology and Ecology 31: 209-221.

Levin, L., N. Blair, D. DeMaster, G. Plaia, W. Fornes, C. Martin and C. Thomas. 1997. Rapid subduction of organic matter by maldanid polychaetes on the North Carolina slope. Journal of Marine Research 55: 595-611.

Levin, L., N. Blair, C. Martin, D. DeMaster, G. Plaia and C. Thomas. In press. Macrofaunal processing of phytodetritus at two sites on the Carolina margin: in situ experiments using ${ }^{13} \mathrm{C}$ labeled diatoms. Marine Ecology Progress Series.

Mangum, C. 1964. Activity pattern in the metabolism and ecology of polychaetes. Comparative Biochemistry and Physiology 11: 239-256.

Martens, C.S. 1987. Labile organic matter input and benthic biogeochemical cycling processes in continental slope sediments, p. 211-222. U.S. GOFS Planning Report \#6.

Mellor, C.A. and C.K. Paull. 1994. Sea Beam bathymetry of the Manteo 467 Lease Block off 
Cape Hatteras, North Carolina. Deep-Sea Research 41: 711-718.

Middelburg, J.J. 1989. A simple rate model for organic matter decomposition. Geochimica et Cosmochimica Acta 53: 1577-1581.

Premuzic, E.T., C.M. Benkovitz, J.S. Gaffney and J.J. Walsh. 1982. The nature and distribution of organic matter in the surface sediments of world oceans and seas. Organic Geochemistry 4: 6377.

Romankevich, E.A. 1984. Geochemistry of organic matter in the ocean. Springer-Verlag, Berlin, $334 \mathrm{pp}$.

Schaff, T., L. Levin, N. Blair, D. DeMaster, R. Pope, and S. Boehme. 1992. Spatial heterogeneity of benthos on the North Carolina continental slope: Large $(100 \mathrm{~km})$-scale variation. Marine Ecology Progress Series 88: 143-160.

Sun, M.-Y., C. Lee and R.C. Aller. 1993. Anoxic and oxic degradation of ${ }^{14} \mathrm{C}$-labeled chloropigments and $\mathrm{a}^{14} \mathrm{C}$-labeled diatom in Long Island Sound sediments. Limnology and Oceanography 38: 1438-1451. 
Tanaka N., K.K. Turekian and D.M. Rye. 1991 . The radiocarbon, $\delta^{13} \mathrm{C},{ }^{210} \mathrm{~Pb}$, and ${ }^{137} \mathrm{Cs}$ record in boxcores from the continental margin of the Middle Atlantic Bight. American Journal of Science 291: $90-105$.

Thomas, C.J. 1998. Individual Deposit-feeder, Community and Ecosystem Level Controls on Organic Matter Diagenesis in Marine Benthic Environments. Ph.D. thesis, North Carolina State University, Raleigh, NC.

Thomas, C.J. , N.E. Blair, D.J. DeMaster, R.A. Jahnke, and C.S. Martens. Submitted. A benthic carbon budget for the continental slope off Cape Hatteras, N.C.. Deep-Sea Research.

Ullman, W.J. and R.C. Aller. 1982. Diffusion coefficients in near-shore marine sediments. Limnology and Oceanography 27: 552-556.

Walsh, J.J. 1994. Particle export at Cape Hatteras. Deep-Sea Research II 41: 603-628.

Walsh, J.J., E.T. Premuzic, J.S. Gaffney, G.T. Rowe, G. Harbottle, R.W. Stoenner, W.L. Balsam, P.R. Betzer and S.A. Macko. 1985. Organic storage of $\mathrm{CO}_{2}$ on the continental slope off the midAtlantic bight, the southeastern Bering Sea, and the Peru coast. Deep-Sea Research 32: 853-883.

Westrich, J.T. and R.A. Berner. 1984. The role of sedimentary organic matter in bacterial sulfate reduction. Limnology and Oceanography 29: 236-249. 
Table 1: Densities and taxonomic composition of North Carolina slope benthic macrofauna. Data are from August 1994 background cores and experimental plots.

$\begin{array}{lcc} & \text { Site I } & \text { Site III } \\ \text { \# of boxcores } & 9 & 8 \\ \text { Individuals m } & \\ \text { Standard error } & 10,249 & 29,362 \\ & 1,145 & 3,734 \\ \text { Percentages of major taxa } & & \\ \text { Polychaetes } & 36.1 & 32.0 \\ \text { Oligochaetes } & 14.6 & 3.9 \\ \text { Crustaceans } & 14.2 & 23.3 \\ \text { Molluscs } & 16.1 & 21.1 \\ \text { Coelenterates } & 9.3 & 11.6 \\ \text { Other } & 9.7 & 8.1\end{array}$


Table 2: Natural abundance ${ }^{14} \mathrm{C}$ contents and ages of fauna and sediment from the Cape Hatteras continental slope region. Positive $\Delta^{14} \mathrm{C}$ values (or negative ${ }^{14} \mathrm{C}$ ages) reflect the addition of ${ }^{14} \mathrm{C}$ produced by the atmospheric testing of nuclear weapons. Positive ${ }^{14} \mathrm{C}$ ages are in years before present (1950).

\begin{tabular}{|c|c|c|c|}
\hline Fauna/Sample & $\begin{array}{c}\text { Depth in } \\
\text { sediment }(\mathrm{cm})\end{array}$ & $\Delta^{14} \mathrm{C}$ (s.d.) & $\begin{array}{l}{ }^{14} \mathrm{C} \text { age } \\
\text { (years) } \\
\end{array}$ \\
\hline \multirow[t]{2}{*}{ Lumbrineridae $^{1}$} & $10-15$ & $82.5(8.4)$ & -655 \\
\hline & $>15$ & $66.1(5.2)$ & -529 \\
\hline \multirow[t]{2}{*}{ Onuphidae $^{1}$} & $5-7$ & $77.9(6.8)$ & -620 \\
\hline & $9-11$ & $80.4(5.8)$ & -667 \\
\hline \multirow[t]{3}{*}{ Maldanidae $^{1}$} & $?$ & $47.9(7.0)$ & -388 \\
\hline & $10-11$ & $53.5(8.7)$ & -431 \\
\hline & $10-15$ & $58.1(8.3)$ & -467 \\
\hline \multirow[t]{2}{*}{ Trichobranchidae $^{1}$} & $1-2$ & $40.3(8.7)$ & -348 \\
\hline & $10-15$ & $47.0(7.0)$ & -380 \\
\hline Goniadidae $^{1}$ & $2-5$ & $48.0(6.1)$ & -388 \\
\hline Cirratulidae $^{1}$ & $2-5$ & $19.5(6.8)$ & -160 \\
\hline $\begin{array}{l}\text { Lysenchelys } \\
\text { verrillii }^{2}\end{array}$ & & $73.8(6.8)$ & -589 \\
\hline Surface sediments & $0-4$ & -100 to -220 & $\begin{array}{l}+870 \text { to } \\
+2050\end{array}$ \\
\hline
\end{tabular}


Table 3: Examples of heavily ${ }^{13} \mathrm{C}$-labeled macrofauna from 1-1.5 d experiments. Background (nonlabeled) $\delta^{13} \mathrm{C}$ values of annelids and agglutinating protozoans at Site I were $-16.5 \pm 0.3 \%$ and $-18.7 \pm 0.2 \%$, respectively. Background annelid, non-annelid and agglutinated protozoan $\delta^{13} \mathrm{C}$ values were $-19.0 \pm 0.2 \%$, $-19.8 \pm 0.8 \%$ and $-20.0 \pm 0.1 \%$ at Site III.

Site I

Site I

\section{Annelids}

Melinna sp.

Cirratulid

Ceratocephale sp.

Protozoans

Mudball (foram)

Astrorhiza-like

Bathysiphon rufum $\underline{\delta^{13} \mathrm{C}}$

$+166$

$+47$

$+317$

$+305$

$+380$

$+930$
Site III

$\underline{\delta^{13} \mathrm{C}}$

\section{Annelids}

Melinna sp.

$+1160$

Maldanid

$+1670$

Aricidea sp.

$+7830$

Oligochaete

$+67$

Scalibregma

$+3000$

inflatum

$$
\left(1991,{ }^{13} \mathrm{C}-\right.
$$

\section{Chlorella)}

\section{Other}

Bivalve

$+50$ 
Figure Captions

Figure 1: Study site locations on the North Carolina continental slope.

Figure 2: The concentration of tracer carbon in the POC fraction as a function of depth in the seabed at Sites I and III. Open circles represent $T=0$ controls. The closed triangles are concentrations after $1.5 \mathrm{~d}$ on the seafloor. Graphical inserts have expanded concentration scales so that subsurface peaks can be seen. The subsurface peaks near $10 \mathrm{~cm}$ at Site III are associated with maldanid feeding chambers.

Figure 3: Depth distribution in the seabed of tracer ${ }^{210} \mathrm{~Pb}$ and ${ }^{113} \mathrm{Sn}$. The ${ }^{210} \mathrm{~Pb}$ and ${ }^{113} \mathrm{Sn}$ were sorbed to the labeled diatom and old slope sediment, respectively. At Site I in the $1.5 \mathrm{~d}$ experiments the two tracers typically tracked each other indicating that transport was not particle selective. However, in the situation shown diatoms were selectively transported to $4-5 \mathrm{~cm}$ relative to the tagged sediment suggesting biological mediation. The plot on the right has an expanded activity scale to show the subsurface peak.

Figure 4: The concentration of tracer carbon in the POC fraction after 14 months. Note the difference in concentration scales between this and Fig. 2. Most of the loss from the plots was due to horizontal transport rather than in situ oxidation as indicated by tracer ${ }^{210} \mathrm{~Pb}$ inventories. The symbols denote data from two separate experimental plots.

Figure 5: Incorporation of tracer carbon by infauna. Plots $5 \mathrm{a}$ and $\mathrm{c}$ illustrate the percent of analyzed individuals that were labelled as a function of major taxon (annelids, non-annelid metazoans and protozoans) and time of exposure to tracer at Sites I and III. $\delta^{13} \mathrm{C}$ values of $-12 \%$ and $-15 \%$ were used as thresholds to determine label uptake at Sites I and III respectively. The numbers shown on the bars are the number of individuals analyzed. Plots $b$ and $d$ show the mean 
$\delta^{13} \mathrm{C}$ values of the infauna. Values on the bars are the standard deviations for the means.

Figure 6: The concentration of tracer diatom carbon in the DIC fraction after 1.5 days. Oxidation of emplaced diatoms was largely localized at the surface at Site I. DIC transport into the seabed was controlled by molecular diffusion. At Site III, oxidation occurred at depth. Note the subsurface peaks near $10 \mathrm{~cm}$ which correspond with those in the POC fraction.

Figure 7: The potential evolution of the rate coefficient for the oxidation of the tracer carbon as a function of time at Site I. The time dependence was estimated by fitting reaction-transport model output to the measured DIC profiles from 1-1.5 d experiments. The model is described in the Appendix. Model parameters were as follows. $C_{0}$ was adjusted to match the depth-integrated inventory of diatom POC. $D_{b}=0.5 \mathrm{~cm}^{2} / y r$ except in some cases the fit was improved if $D_{b}$ was set to $5-10 \mathrm{~cm}^{2} / \mathrm{yr}$ in the upper $1 \mathrm{~mm}$. This higher value may reflect small scale mixing processes that were either natural or the result of experiment manipulations. $D_{0}$, the diffusivity of bicarbonate in seawater, equaled $0.58 \mathrm{~cm}^{2} / \mathrm{d} . \mathrm{T}=0 \mathrm{DIC}$ profiles were used to correct $\mathrm{T}=1,1.5 \mathrm{~d}$ distributions for the oxidation that occurred during core retrieval and storage. The different line types (solid, dash, dot, etc.) correspond to individual experimental plots. 


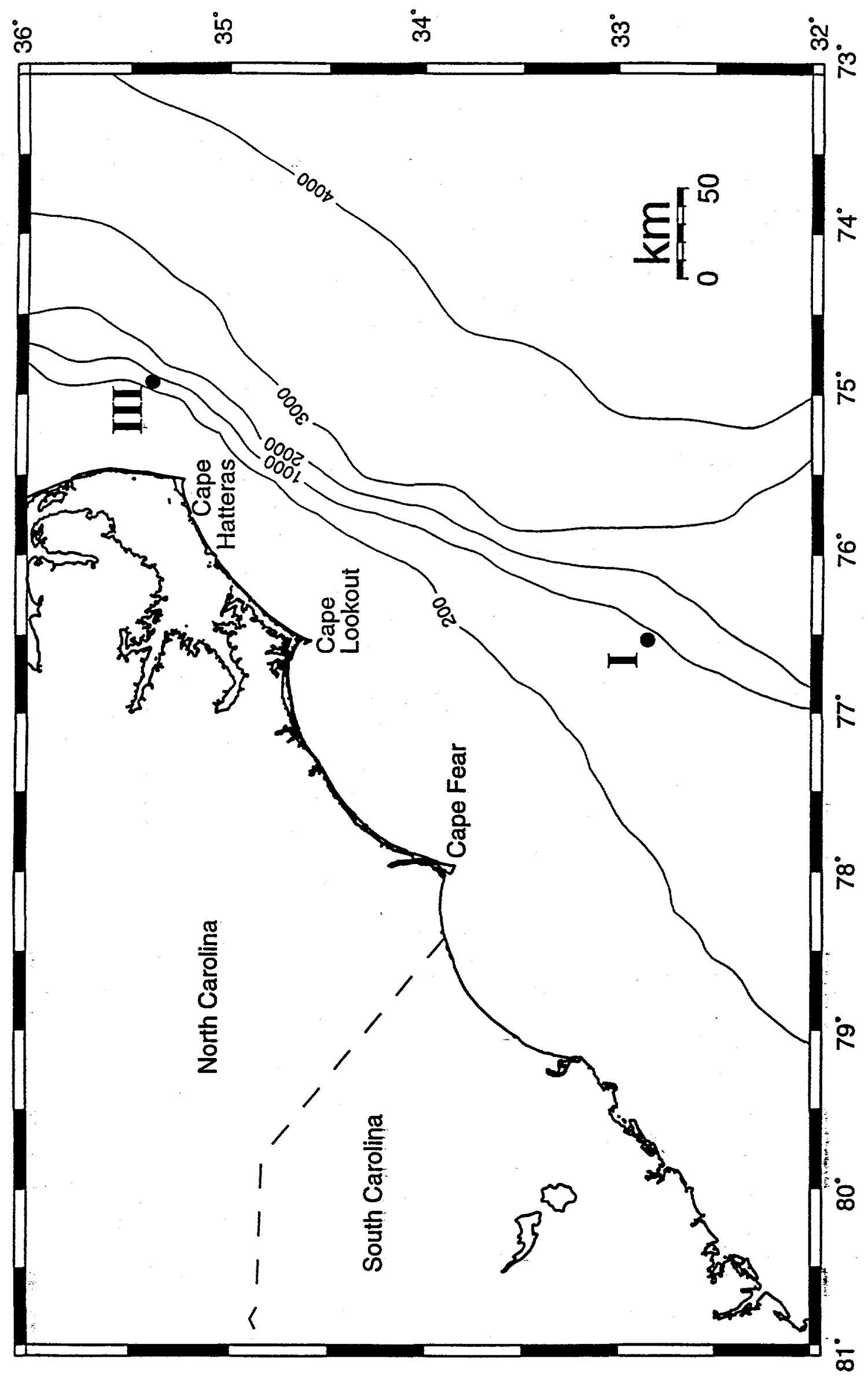



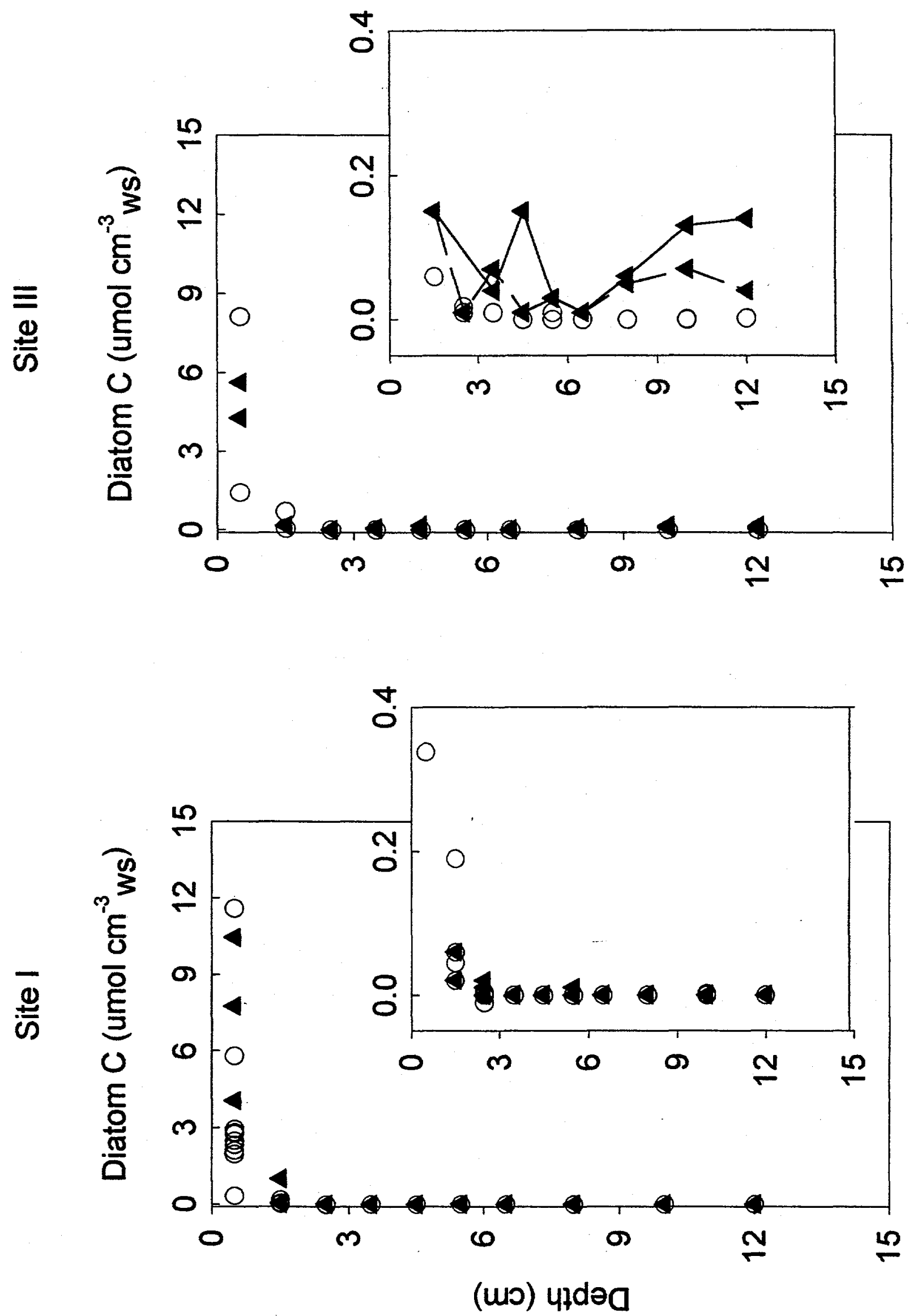
Site I $T=1.5 \mathrm{~d}$

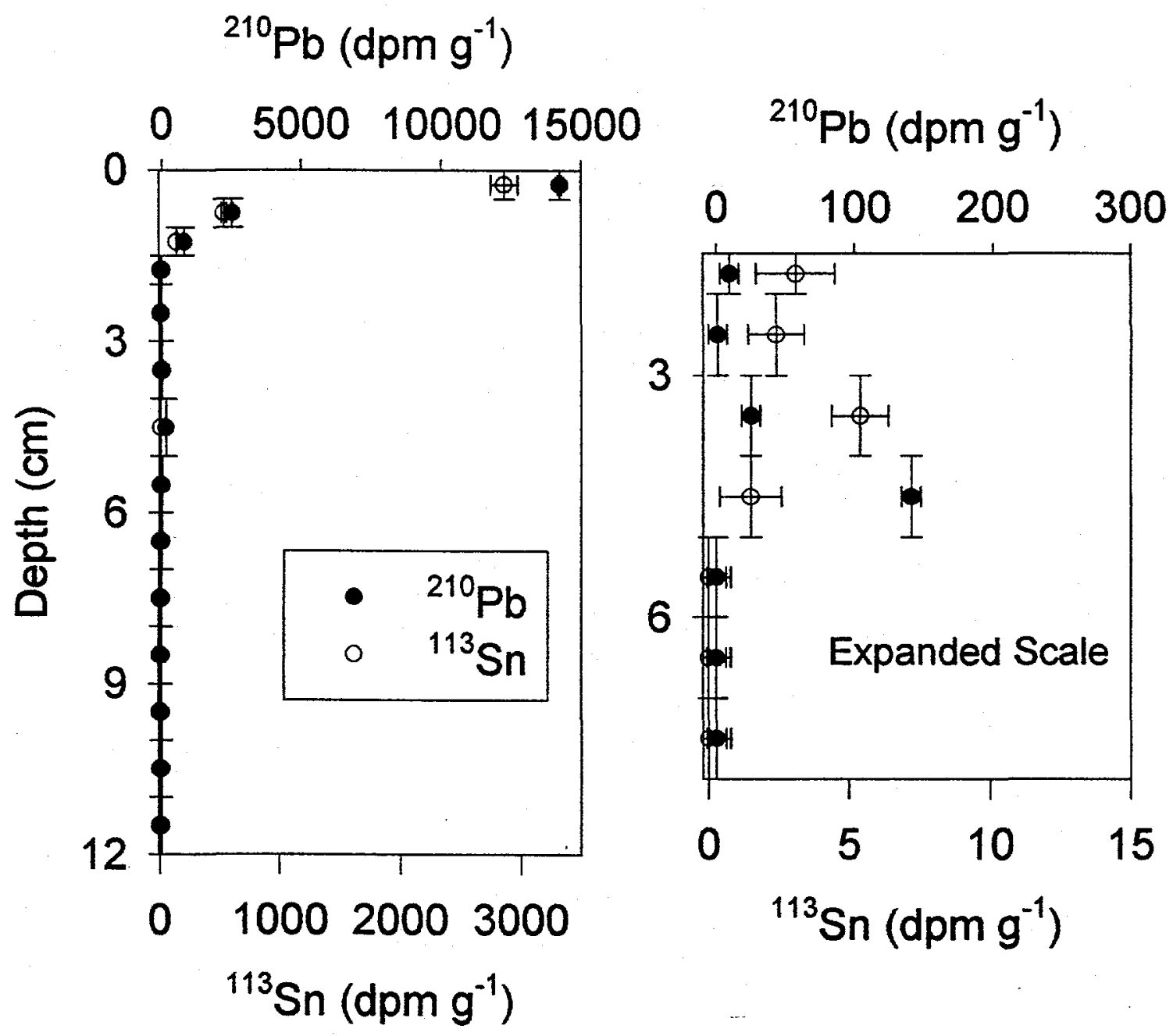

Fig. 3 Blair 

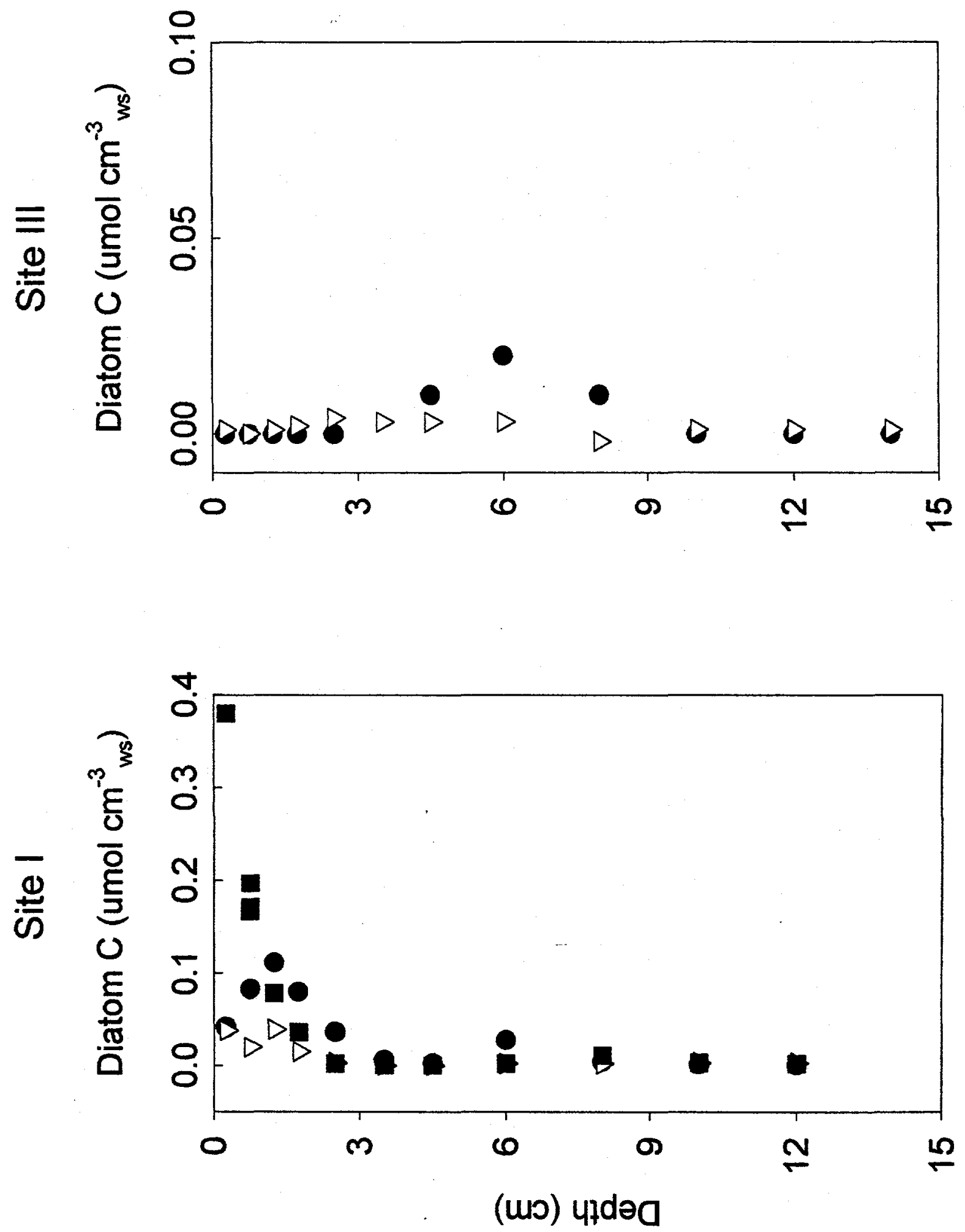


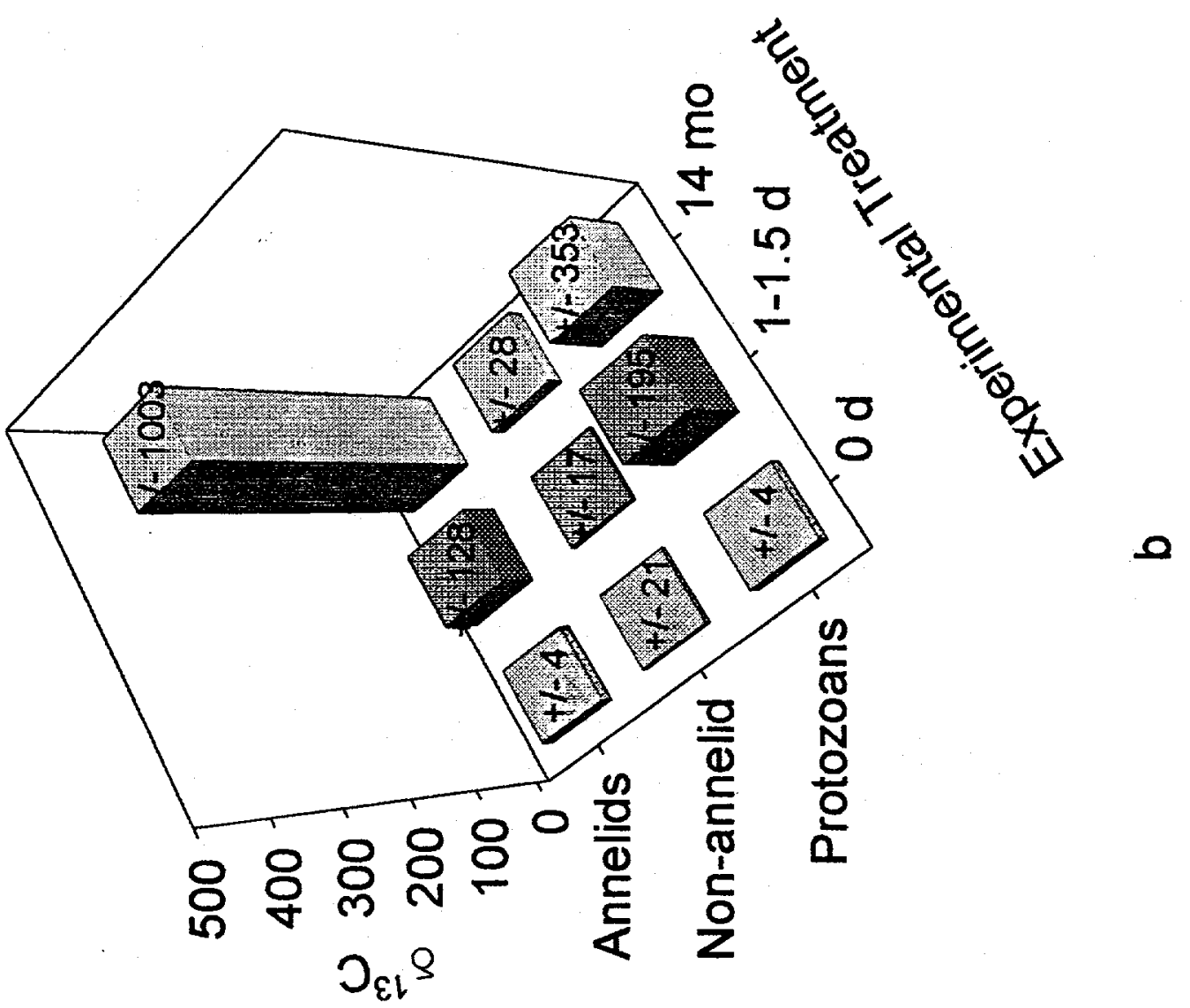

$\overline{\frac{9}{5}}$

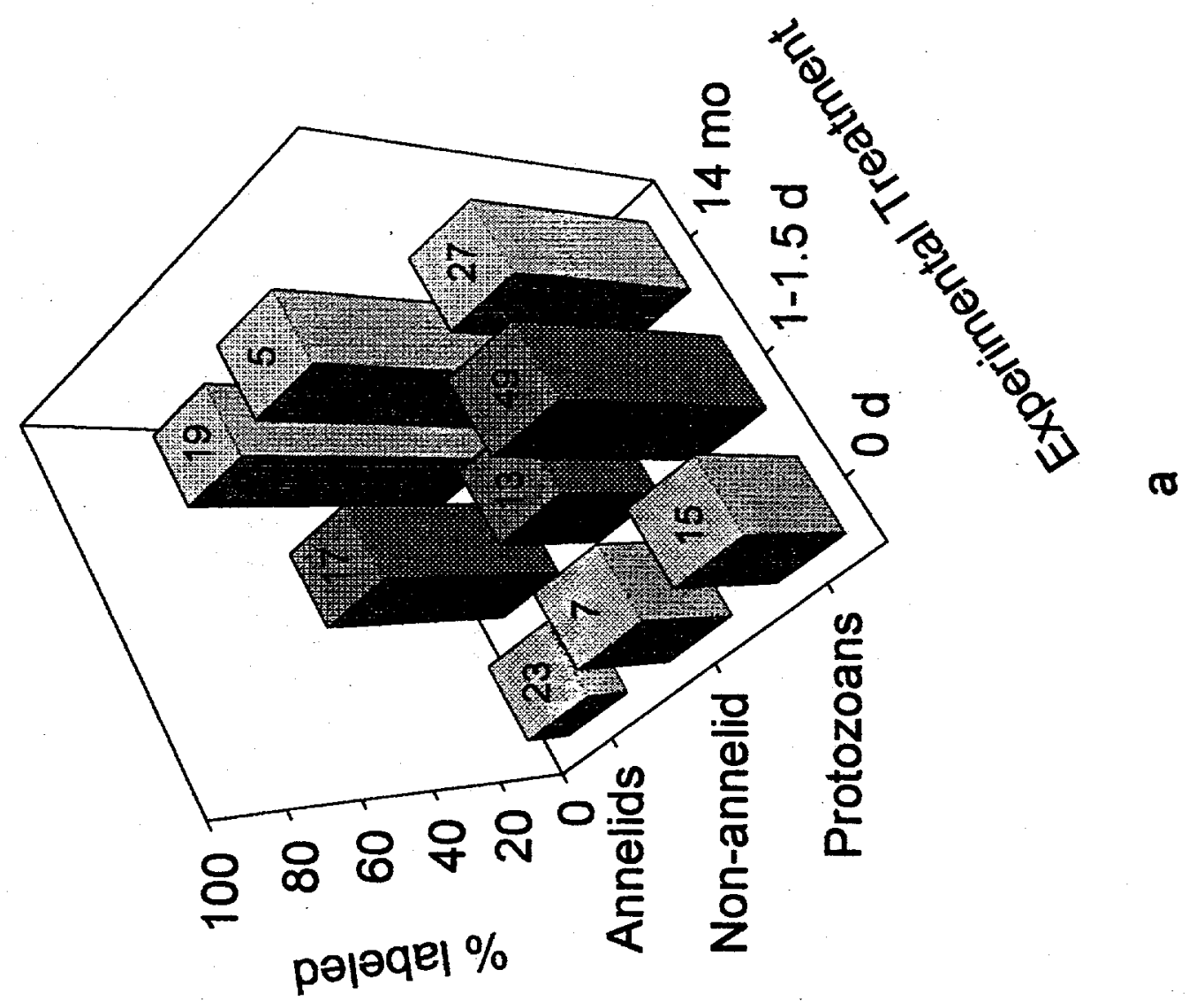

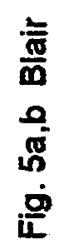




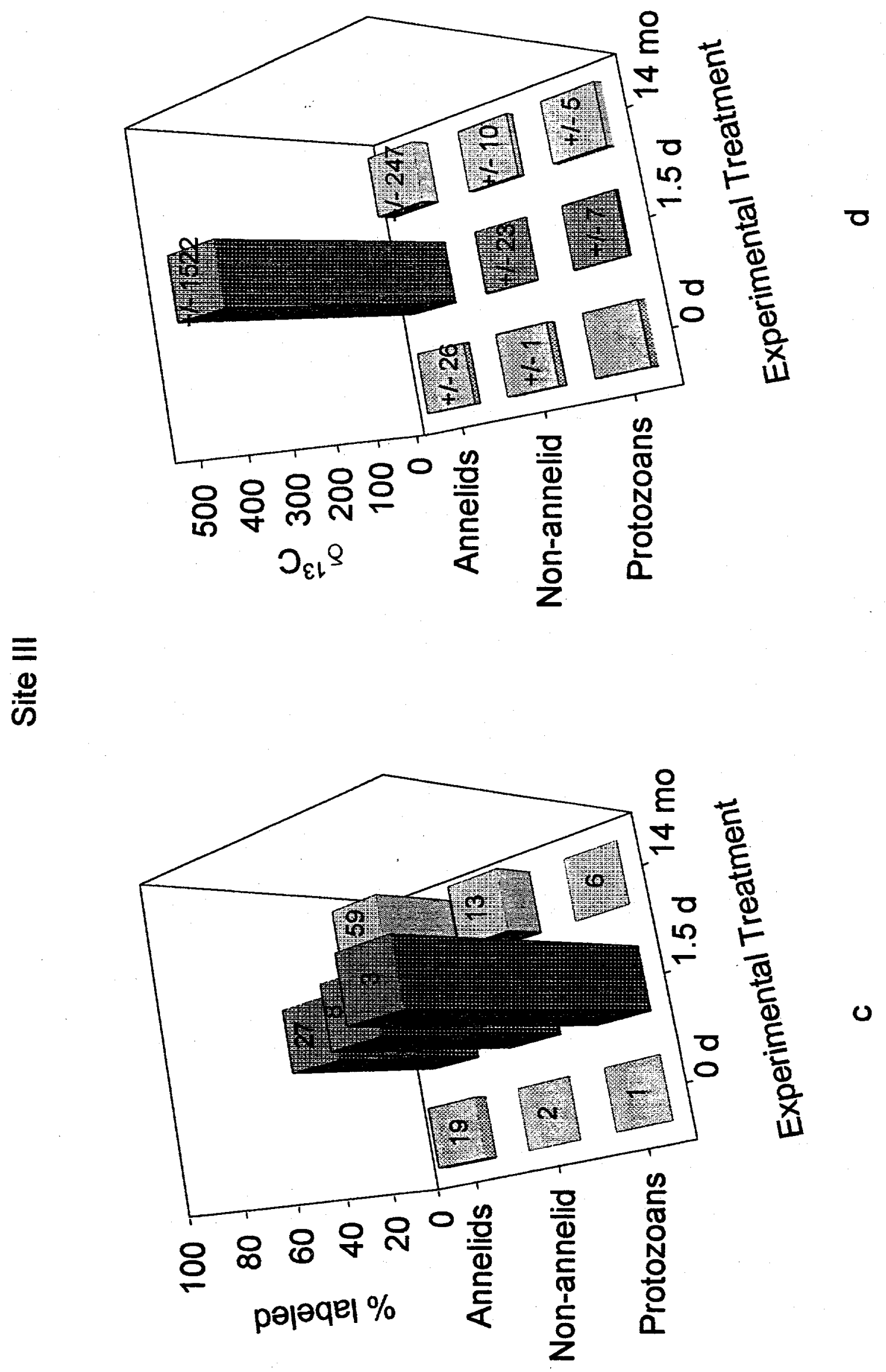

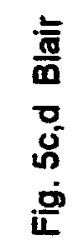



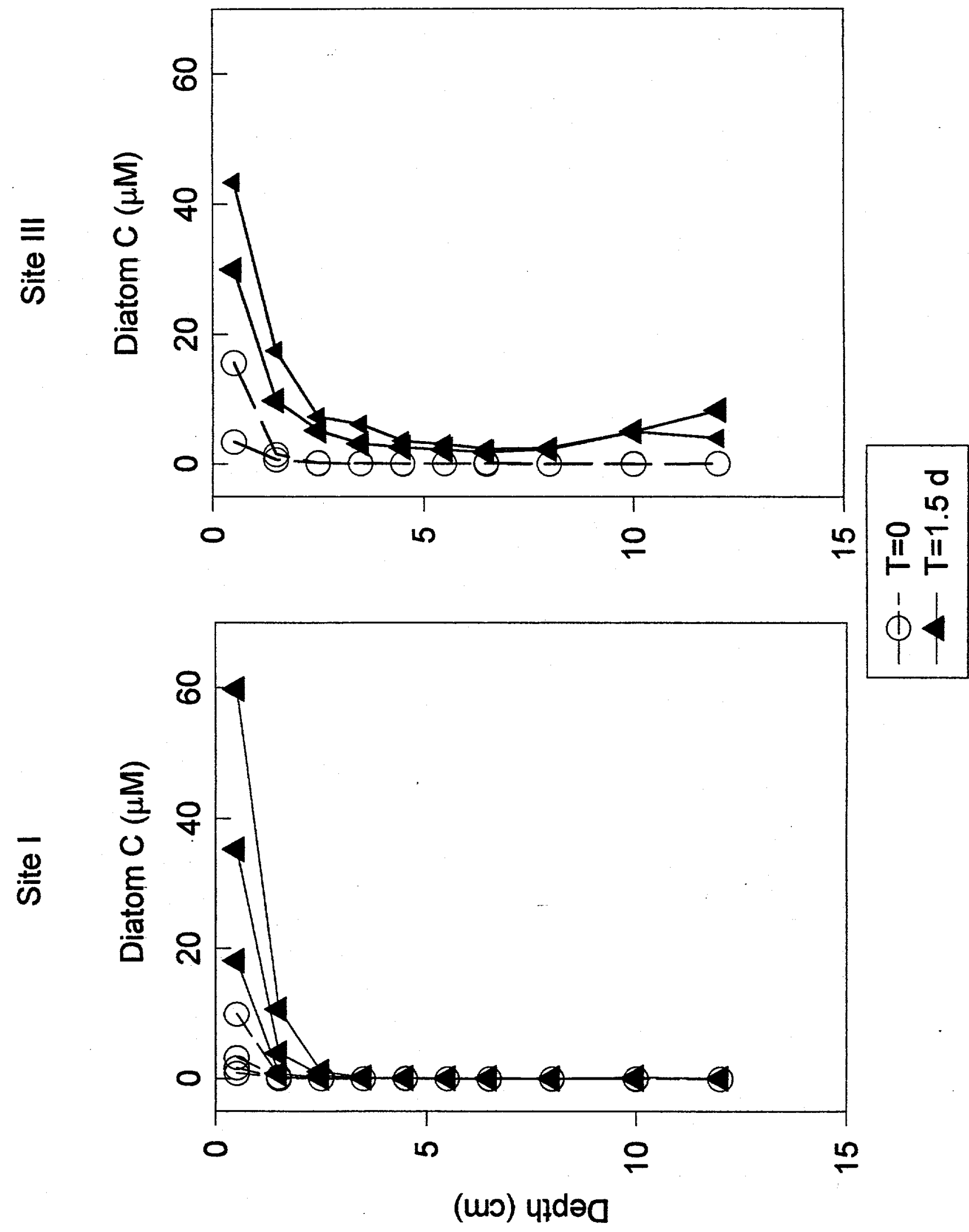


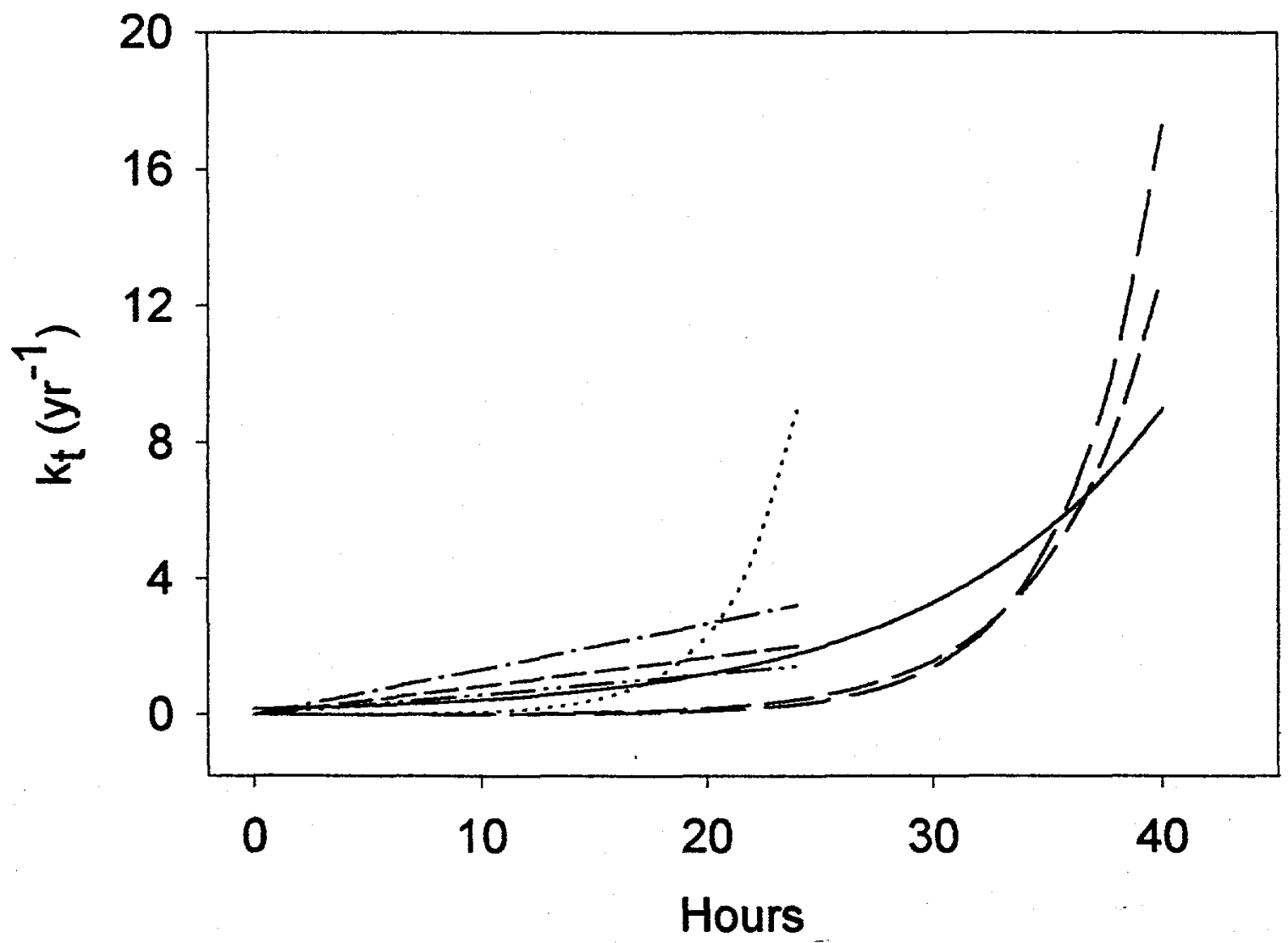

Fig. 7 Blair 